تطبيق نظام الجودة في التعليم الجامعي وتأثيره

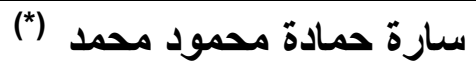

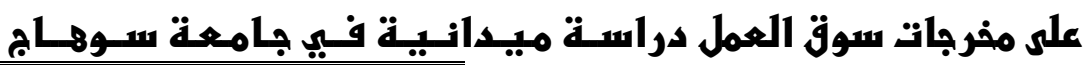

مقدمة:

يشهر المجتمع المصري والمجتمعات العربية بوجه عام في الوقت الراهن واهن والماته

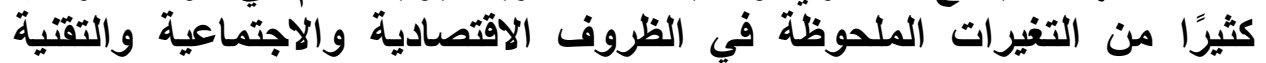

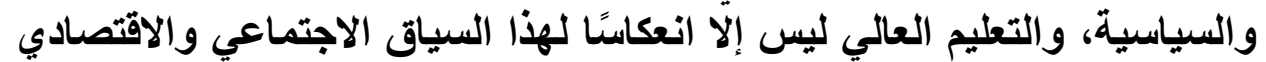

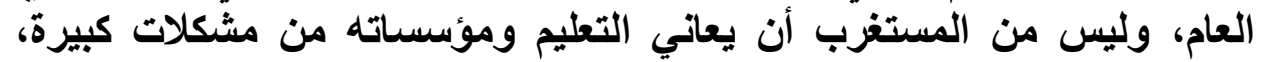

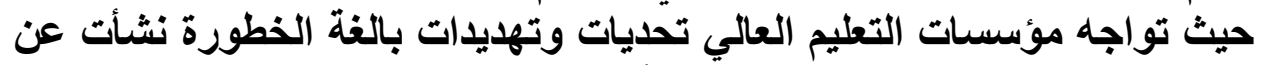

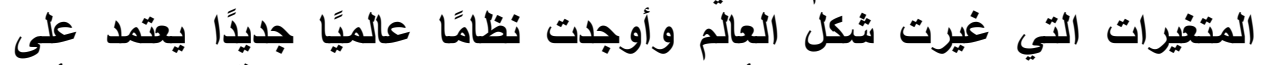

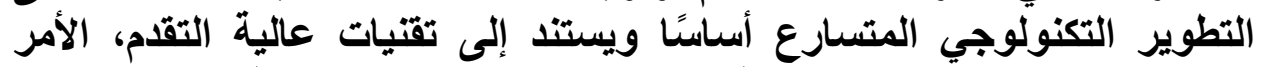

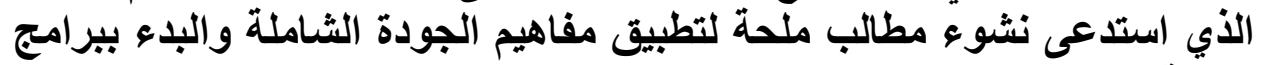

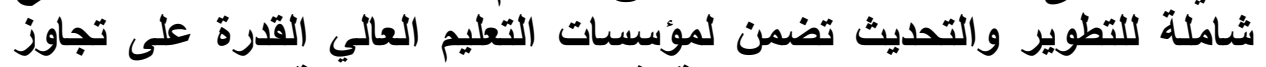

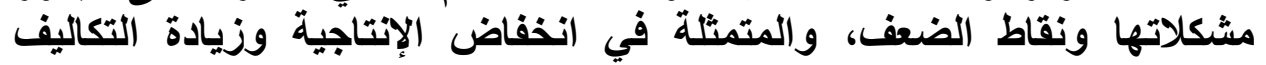

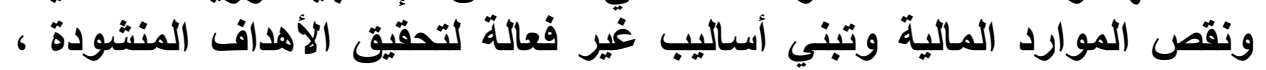

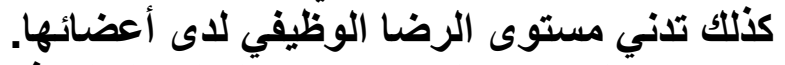

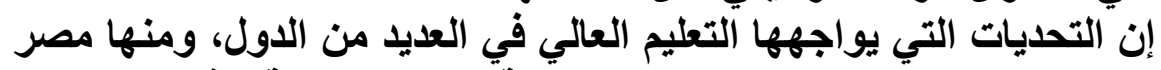

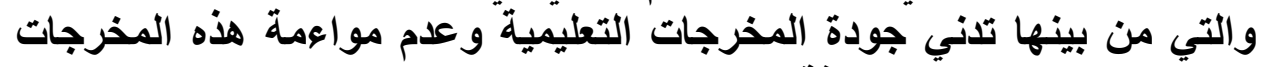

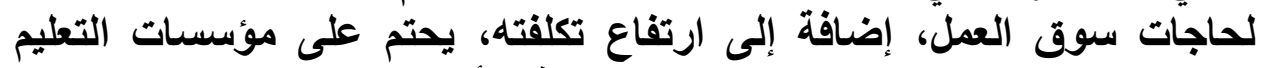

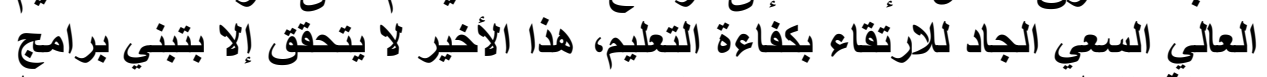

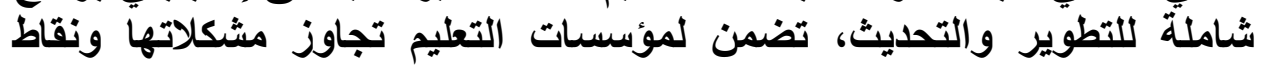

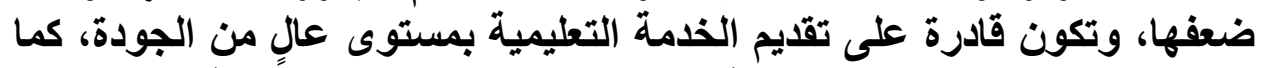

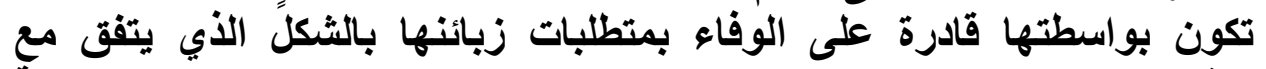

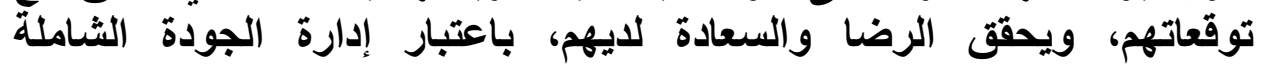
من المفاهيم الإدارية الحديثة التئي (Total Quality Management) ظهرت نتيجة للمنافسة العالمية الثديدة بين مؤسسات الإنتاج الإلية اليابانية

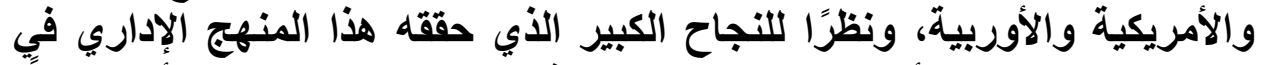

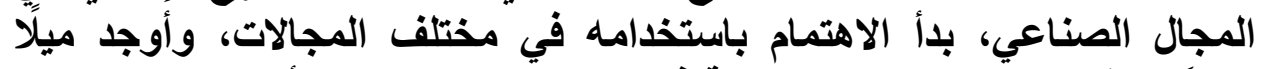
شديدًا لتطبيقه بألمؤسسات التعليمية في العديد من الدول، كما أصبح تقييم التعليم

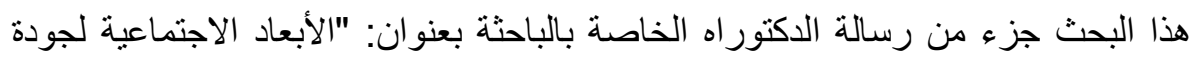

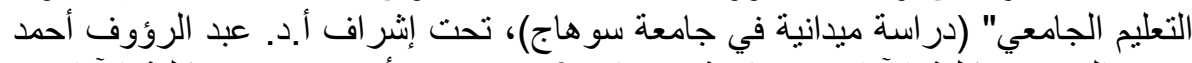

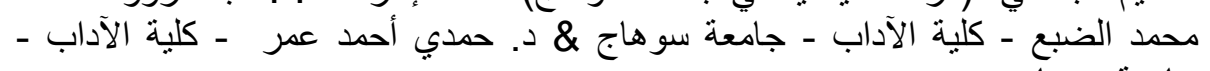
جامعة سو هاج. 
العالي على المستوى العالمي جزءًا لا يتجزأ من العملية التعليمية، وبذللك أصبح

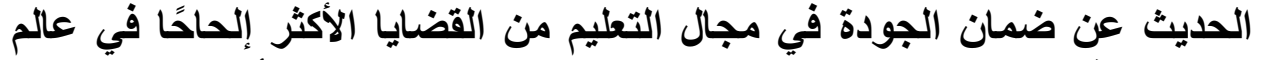

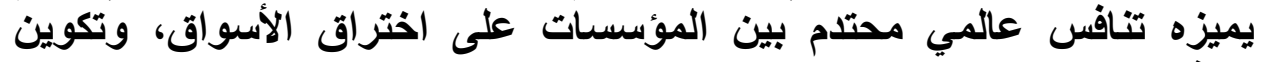

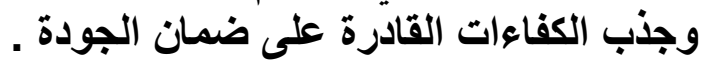

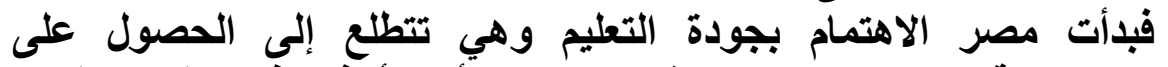

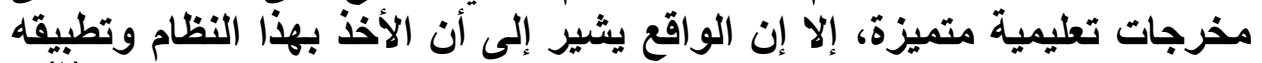

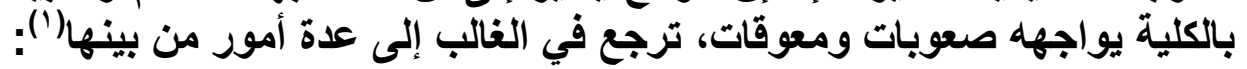

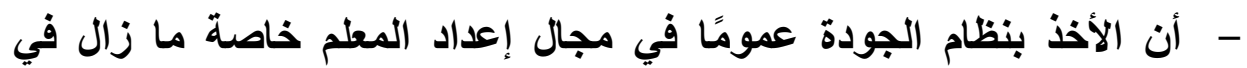

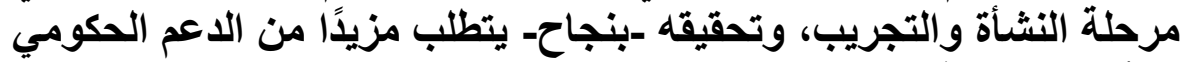

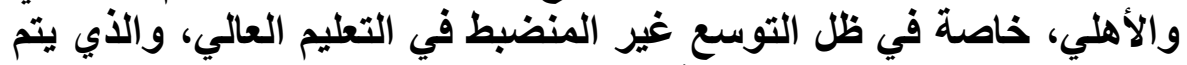

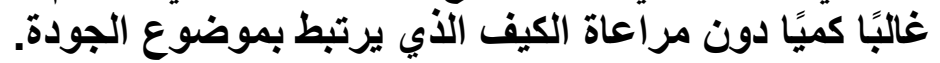

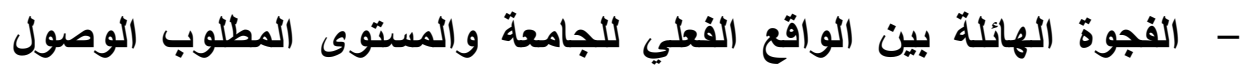

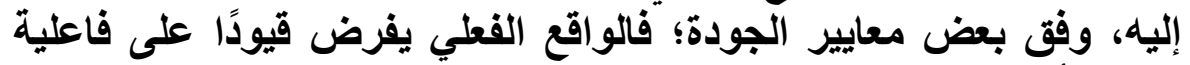

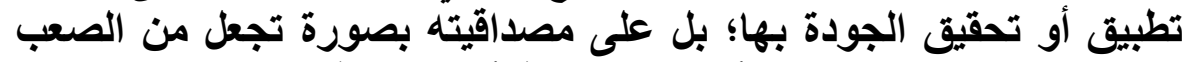

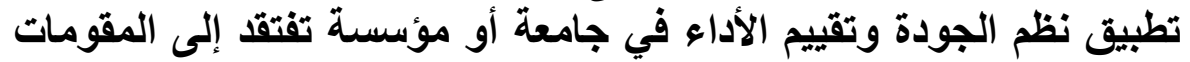
الأساسية اللازمة لتقايم خدمة تعليمية جيدة، تمكنها من تحقيق الأقيق أهدافها،

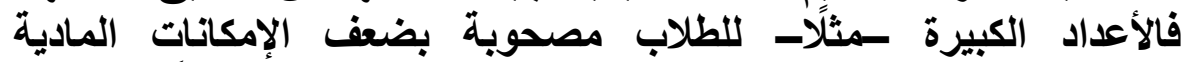

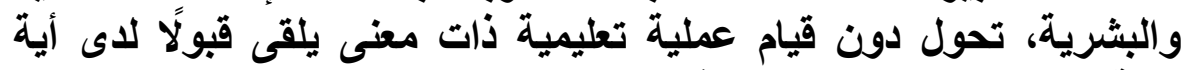
هيئة للاعتماد وضمان الجودة في العالم.

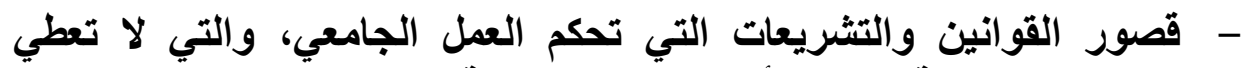
للقيادات الجامعية سلطات أو صلاحيات حقيقية تمكنهم من إحداث التهي التغييرات المطلوية للأخذ بنظام الجودة. ومن هنا سوف تحاول الدراسة التعرف على لجى مدى تطبيق نظام الجودة في التطليم

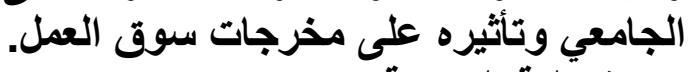

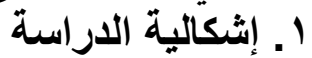

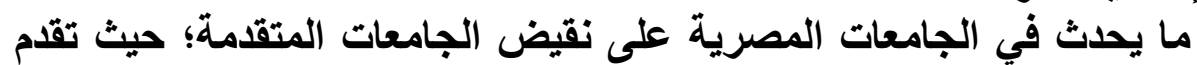

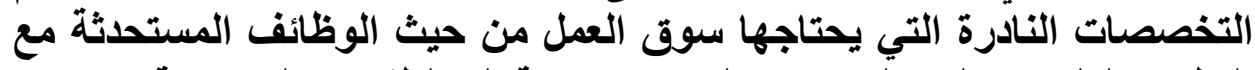

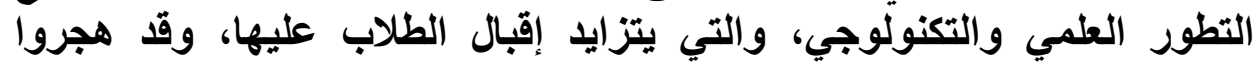

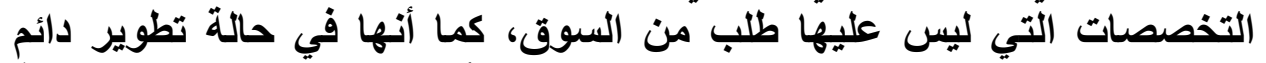

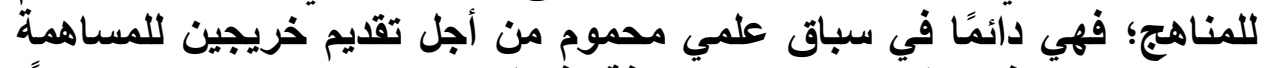

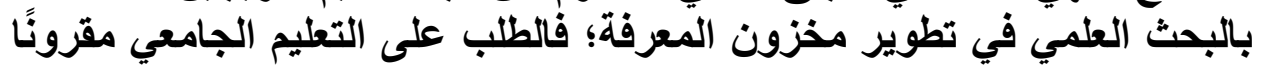

( (1) جمال الدهشان: مشكلات ومعوقات تحقيق الجودة المقارنة و الإدارة التعليمية، نماذج عربية

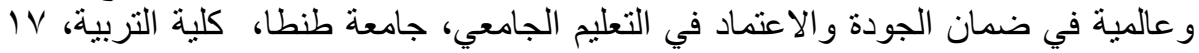




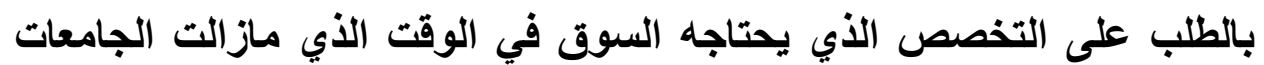

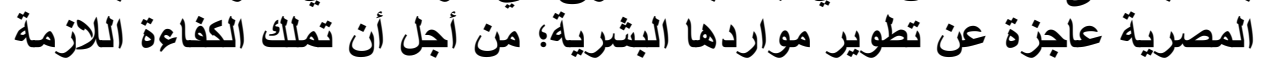

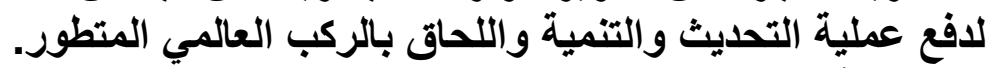

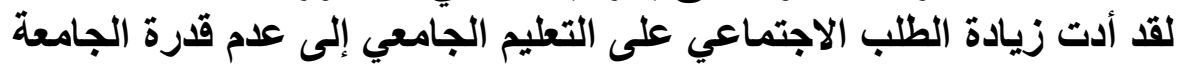

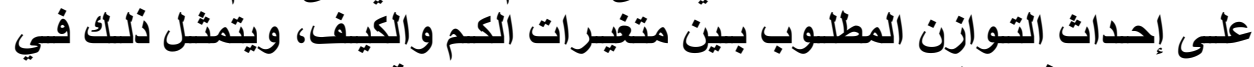

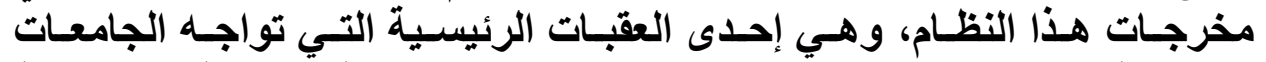

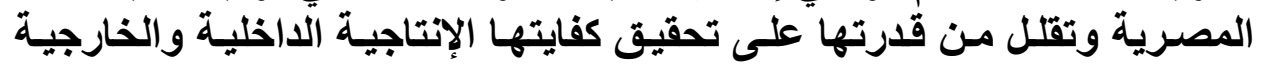

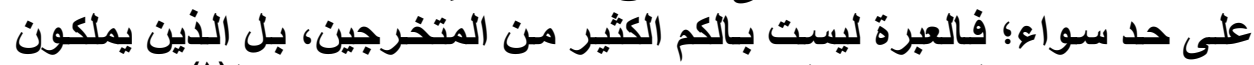

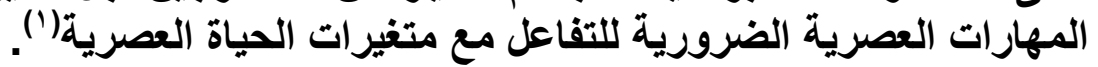

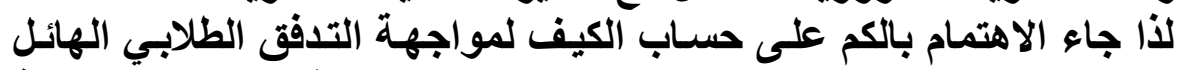

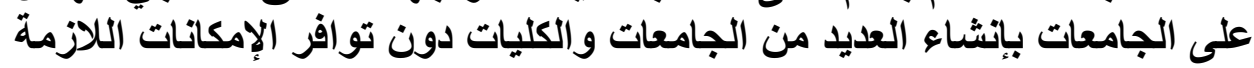

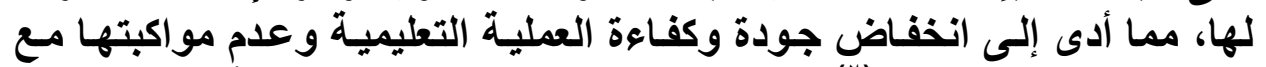

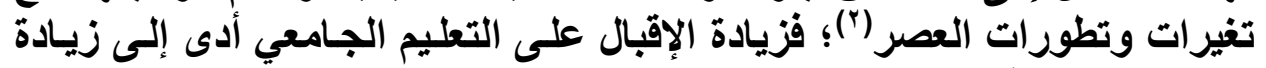

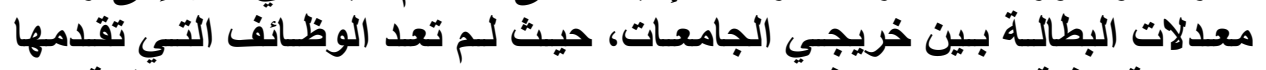

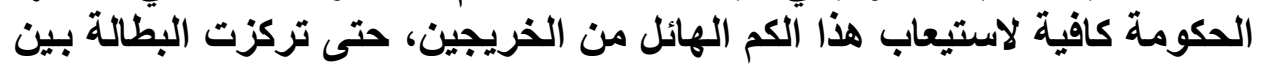

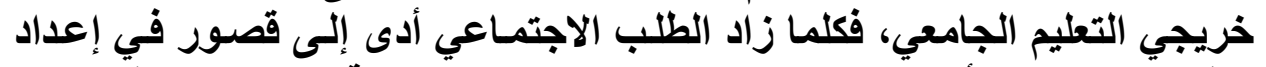

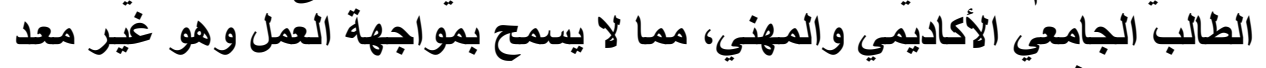

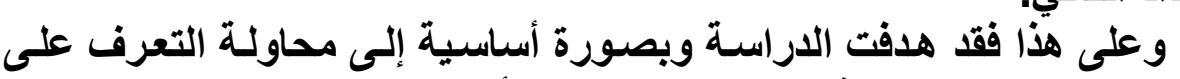

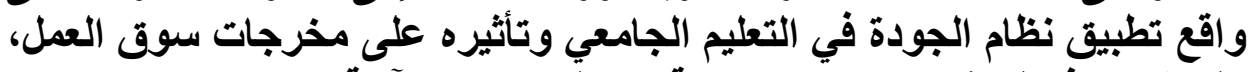

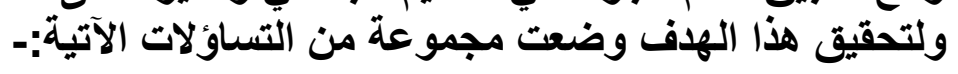

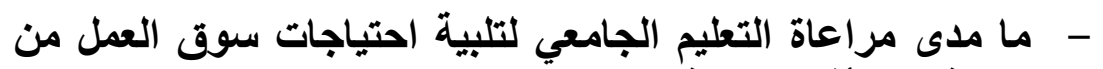

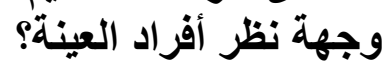

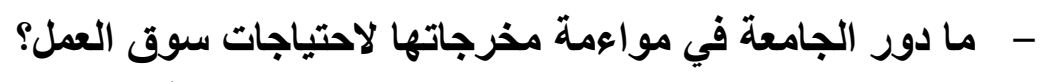

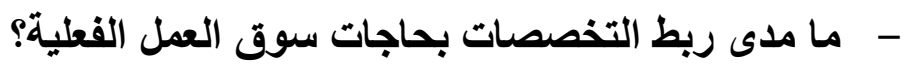

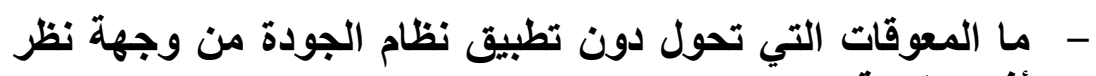
أفراد العينة مالم

(') جابر محمود طلبة: التجديد التربوي من أجل جامعـة المستقبل، المنصسورة، مكتبـة الإيمـان،

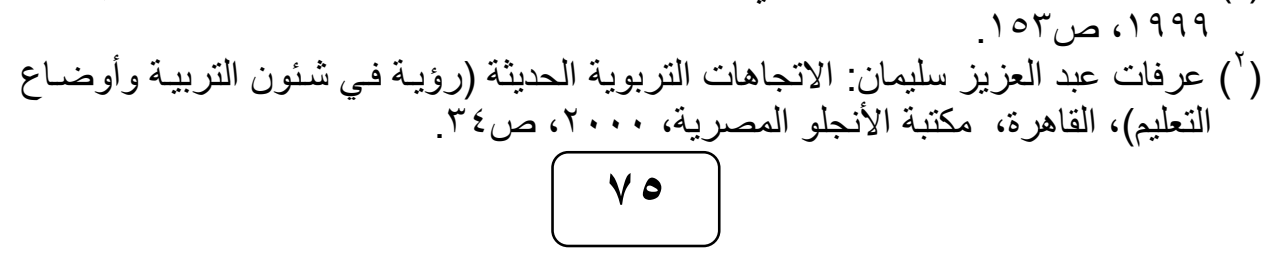




\section{مغاهيم الدراسة:}

\section{:Quality الجودة الجودة}

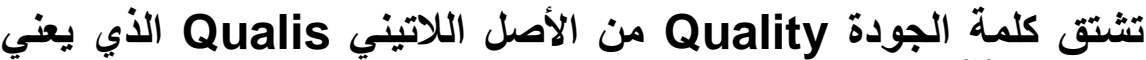

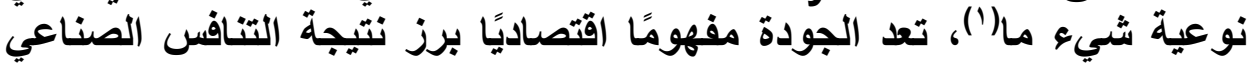

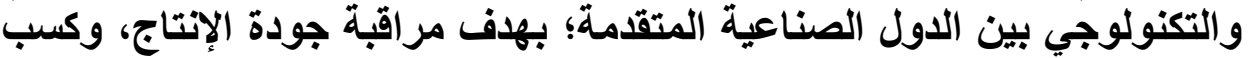

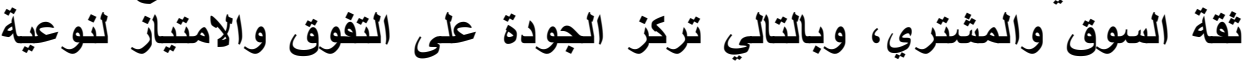

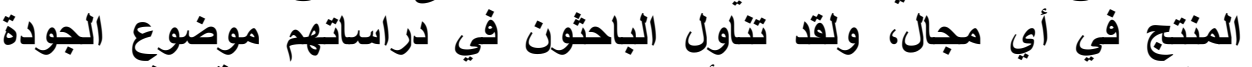

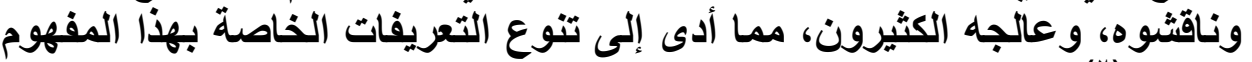

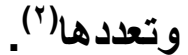

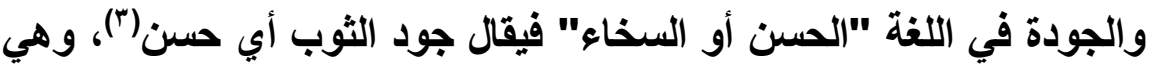

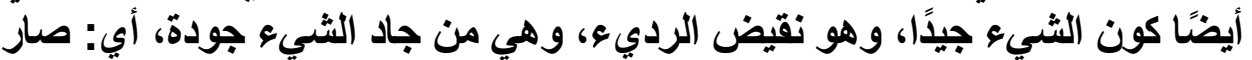

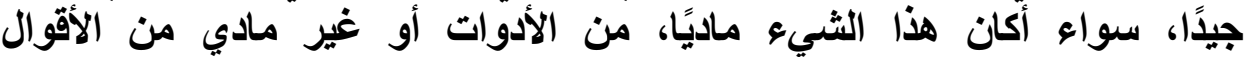

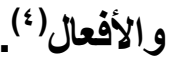
وتعرف في الاصطلاح بأنها إخراج الثيء على أحسن وجه أو أداء ألعاء العمل

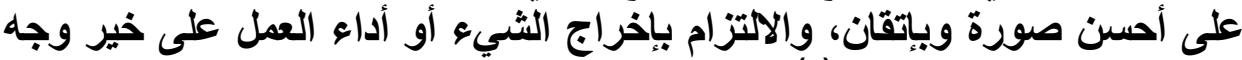
من الحسن والأناقة والإتقان (•). ويعرفها ردوس Rhodes بأنها "عملية استراتيجية إدارية ترتكز على الإنى

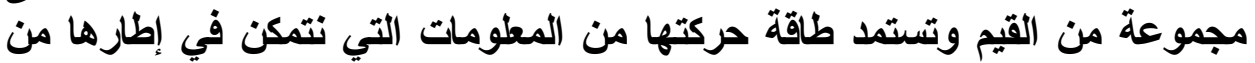

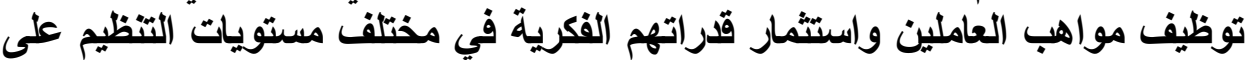

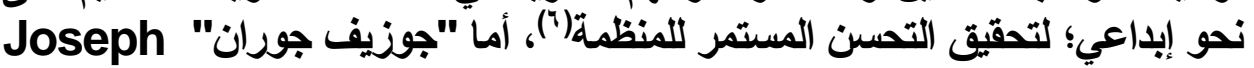
Jouran

(1) Peterson Obara,Magutumop,"Quality Management Pactices Keny an Educational", Institution,The Case Of University Of Nairobi African Journal Of Business\& Management(A), BUMA, $\operatorname{Vol}(1), 2010, P .144$

(2) Bonser, C, "Total Quality Education", Public administration Review, No(52), 1999,P.507.

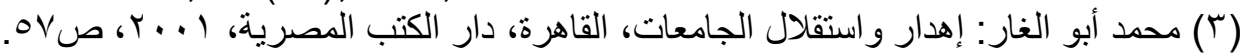

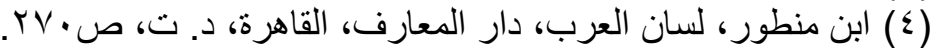

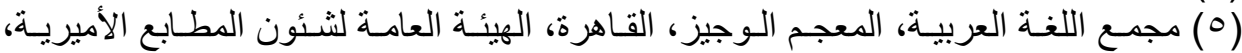
. Iro

$\left({ }^{6}\right)$ Rhodes ,Lewis .A ,." On the road to Quality", Education Leader Ship, Vol. 49, No(6), March,1992, PP.76-80. 
لها تتركز في تتمية برنامج الإتتاج أو الخدمات التي تقابل احتياجات العملاء(")، ويعرفها

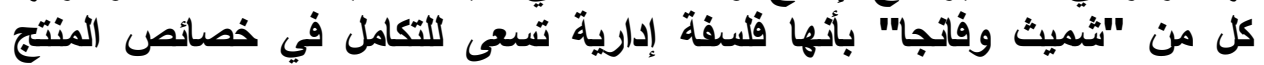

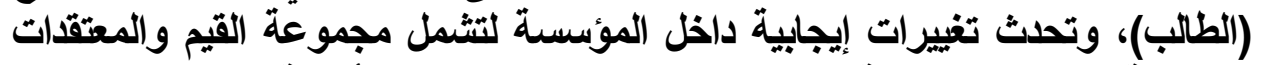

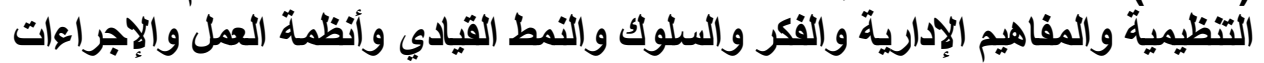

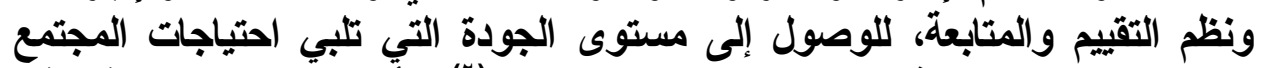

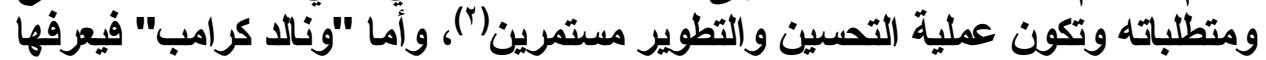

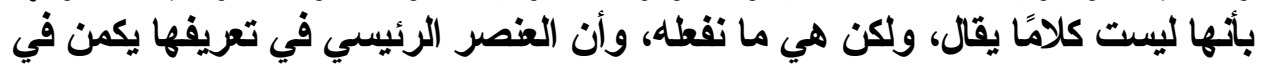

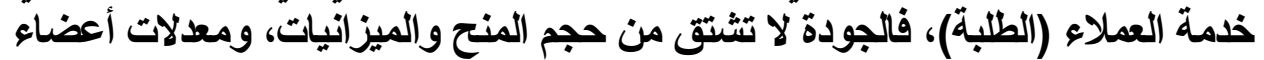

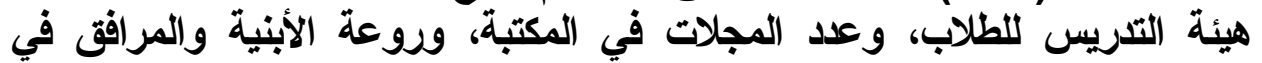

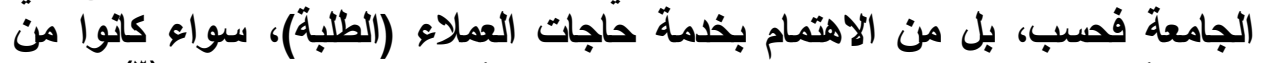

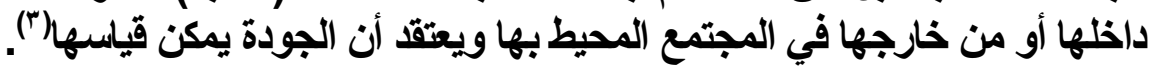

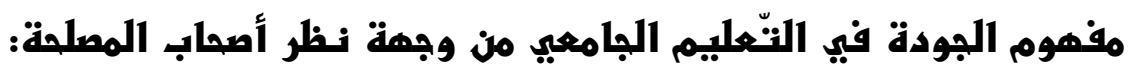

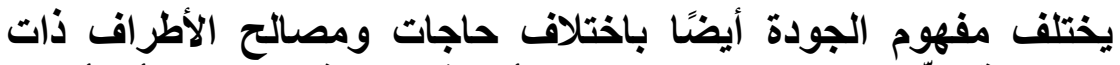

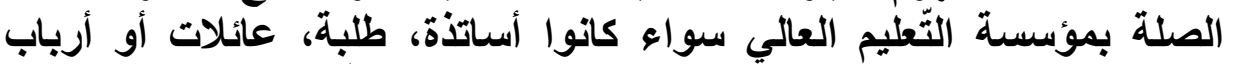

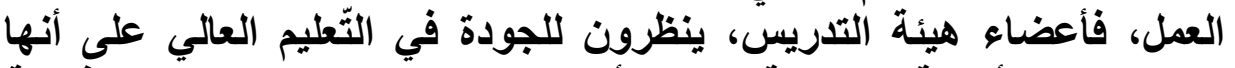

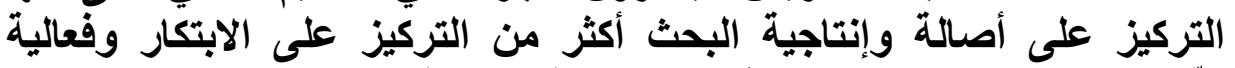

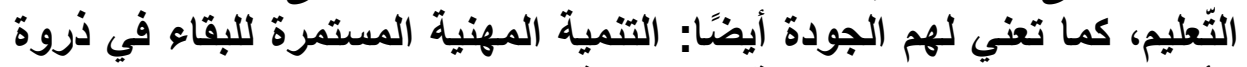

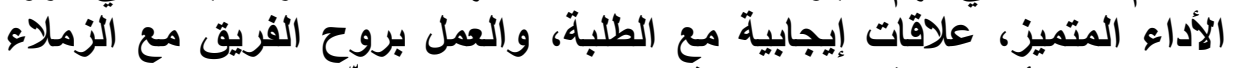

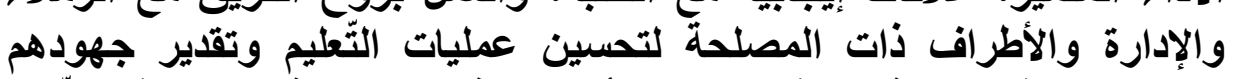

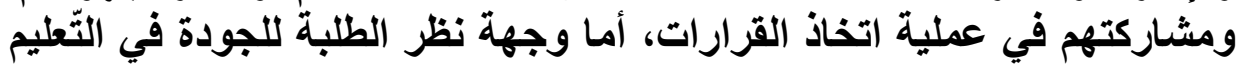

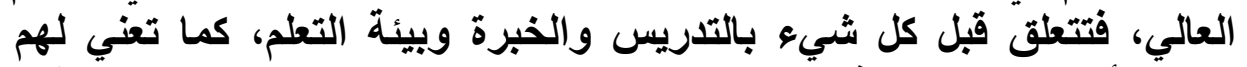

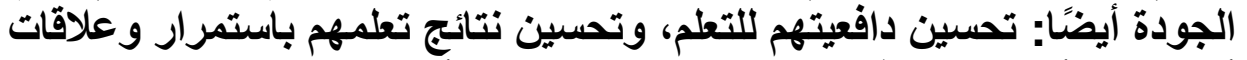

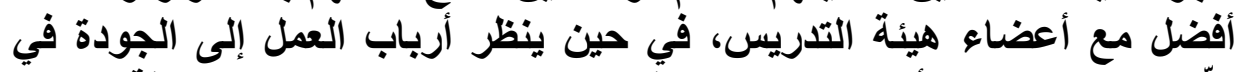

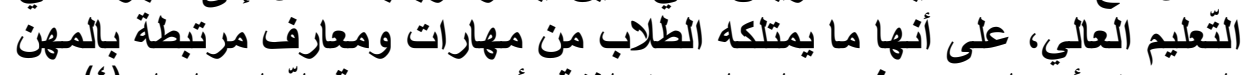

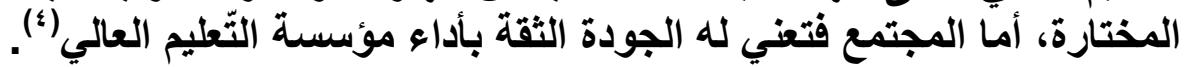

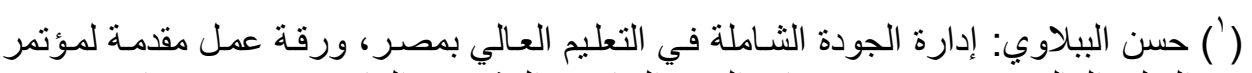

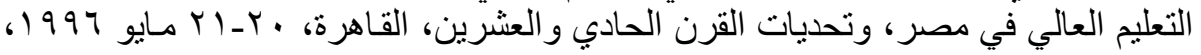

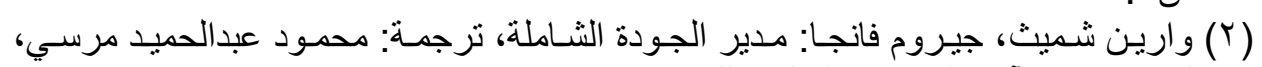

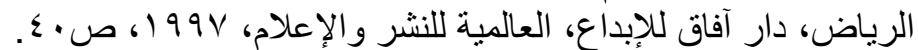

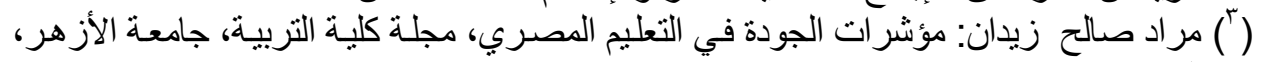

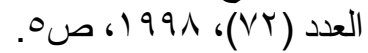

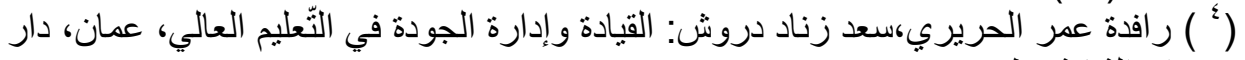

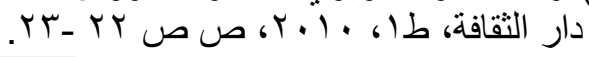

$$
\begin{aligned}
& \text { V V }
\end{aligned}
$$


تطبيق نظام الجودة في التعليم الجامعي وتأثيره على مخرجات سوق العمل

مفهوم جودة التّعليم الجامعي من وجمة نظر بعض الباهثين ومنظمة

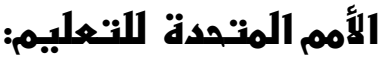

يعدّ مفهوم جودة خدمة التّعليم العالي من المفاهيم التي تتباين حولها ولتها

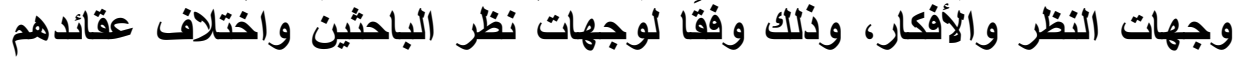

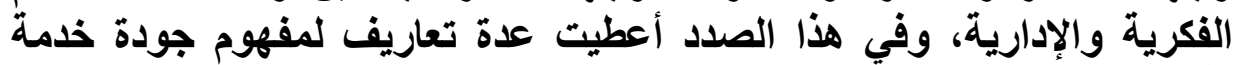

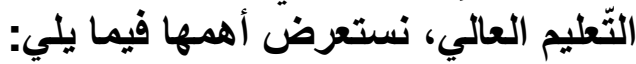

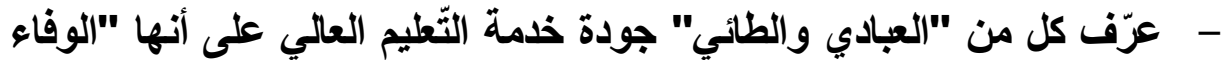

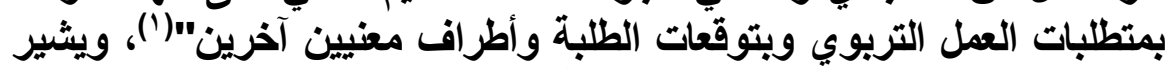

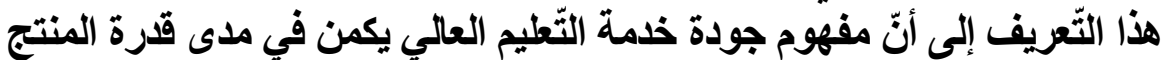

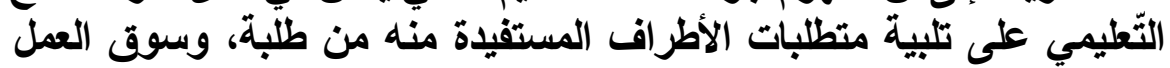

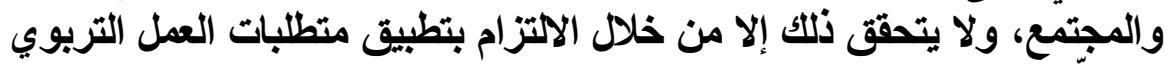

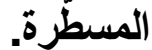

- يعرفها آخر على أنها "تحقيق مجموعة من الاتصالات بالطلبة بهاف توفات

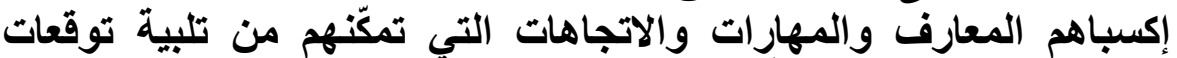

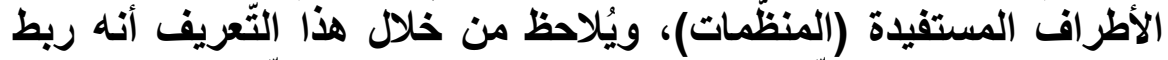

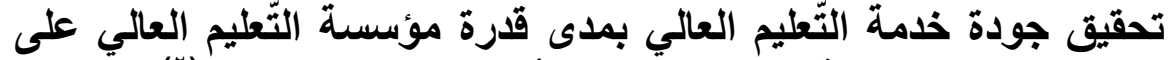

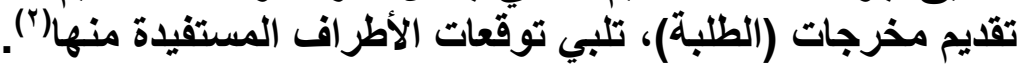

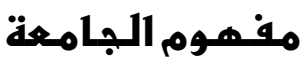

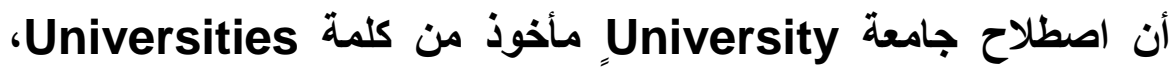

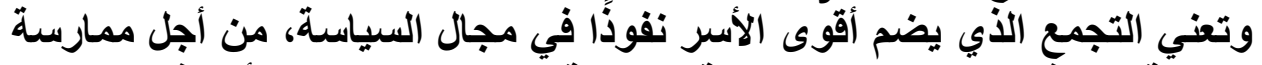

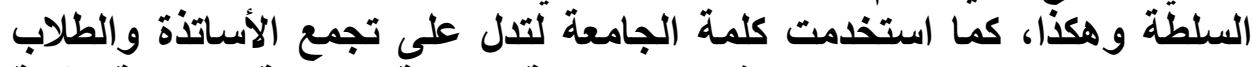

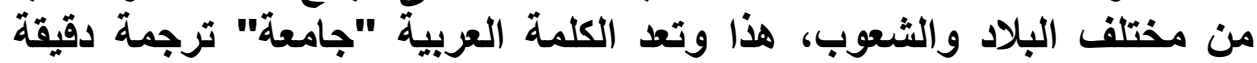
للكلمة الإنجليزية المرادفة لها، لأنها ـفي مدلولها العبة العربي- تعني التجمع درجية والتجميع (آنجا. كما عرفت الجامعة بأنها "مؤسسة للتعليم العالي، والتي تنكون من كلية

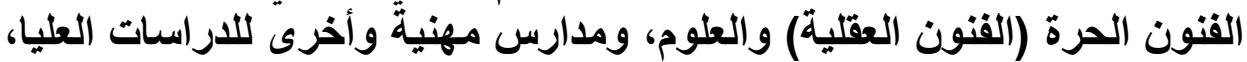
ولها حرية التصرف في شئونها، ويتمتع أفرادها بحرية التعليم والمناقشة، دون الترن

(') هاشم فوزى العبادي وآخرون: إدارة التعليم العالي، ـ مفهوم حديث في الفكر الإداري

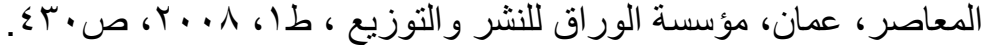

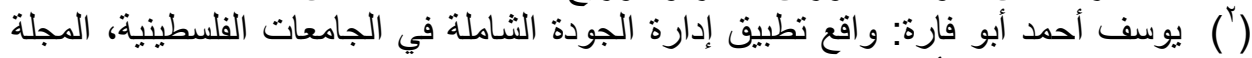

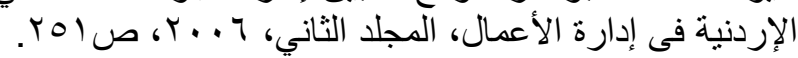
(") محمد مرسي: الاتجاهات الحيثة في التعليم الجامعي الدعاصر وأساليب تدريسه، القاهرة، عالم

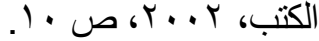


تدخل خارجي، ويلتزم أعضاء هيئة التدريس بها بمستويات علمية وأخلاقية

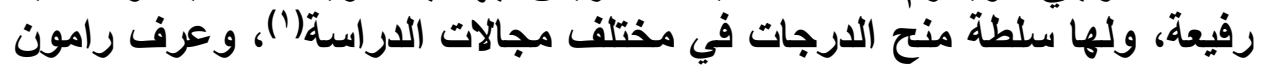

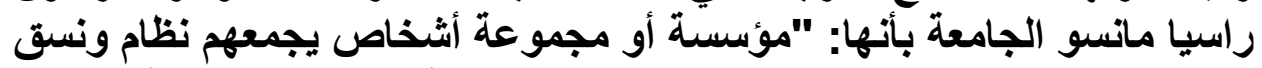
خاصين، تستعمل وسائل وتنسيق بئنان بين مهام مختلفة للوصول بطريقة مائة ما إلى

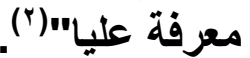

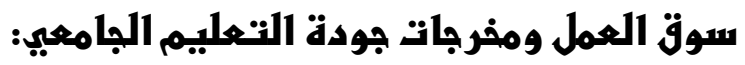

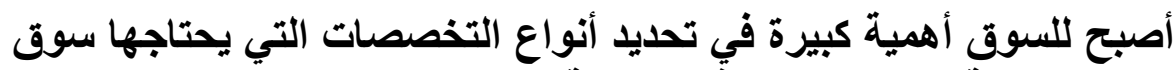

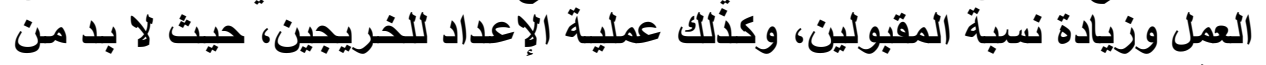

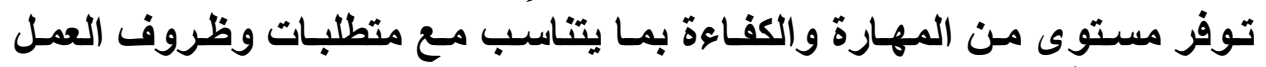

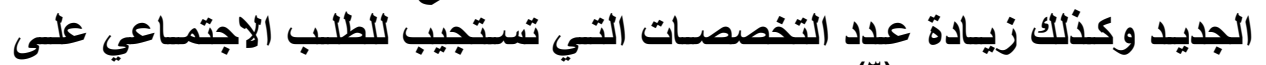
خريجي التعليم الجامعي" (").

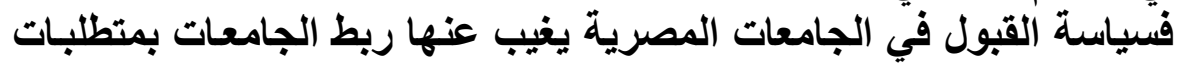

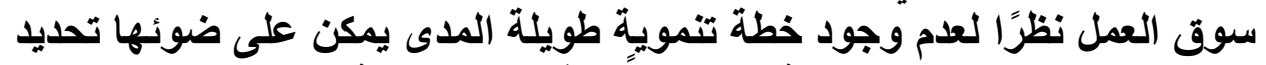

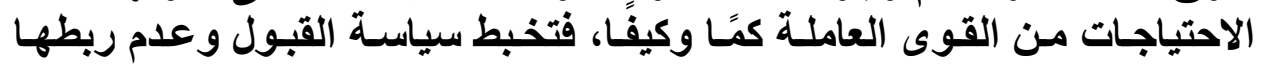

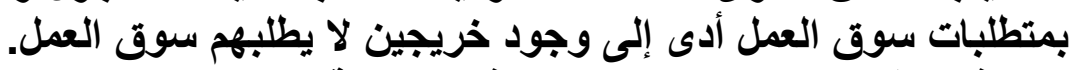

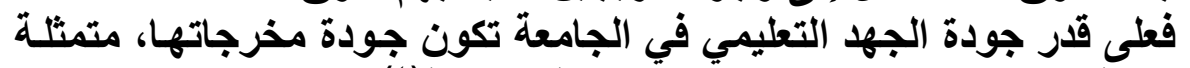

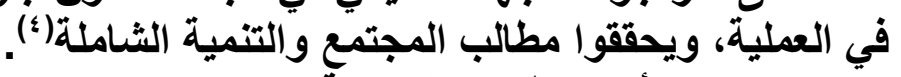

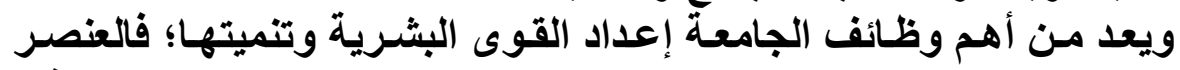

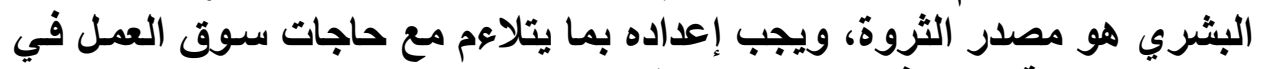

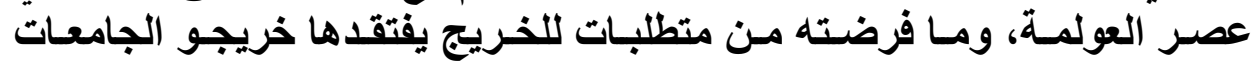

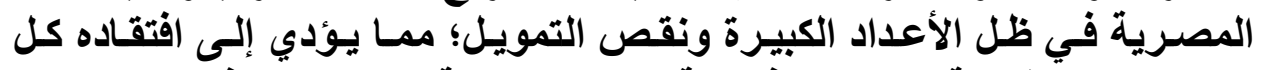

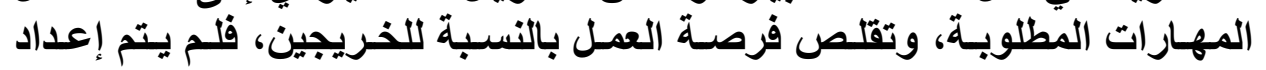

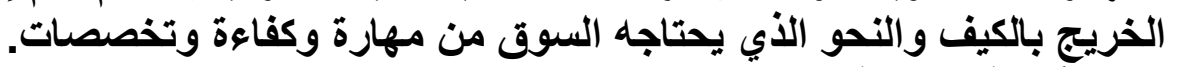

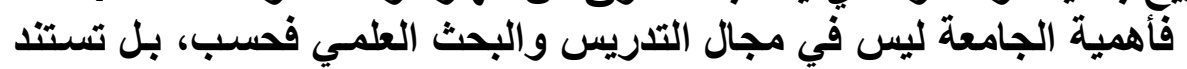

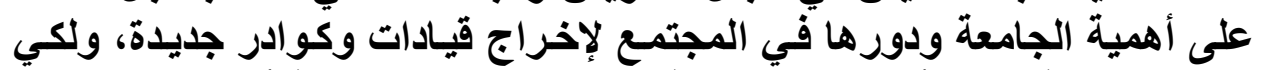

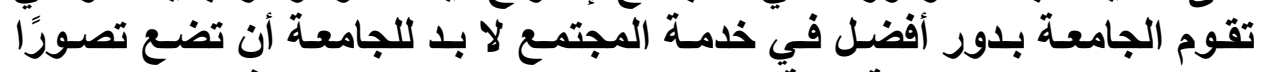
واضح المعالم حول كيفية تلبية حاجات الفرد والمجتمع والتفكير في البرامج التي لتئي

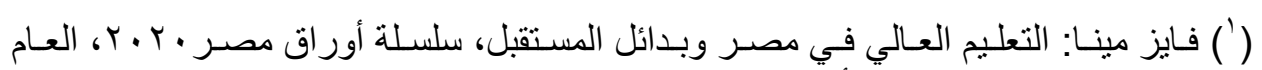

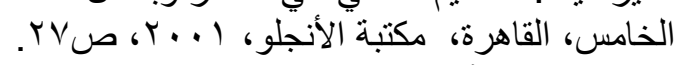

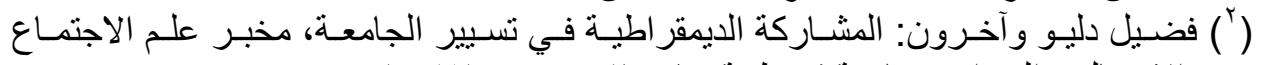

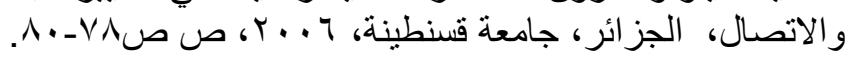

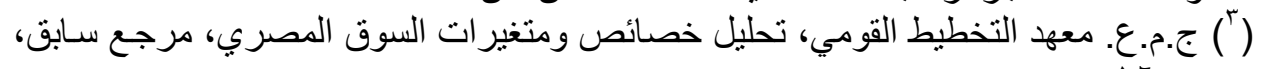

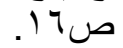

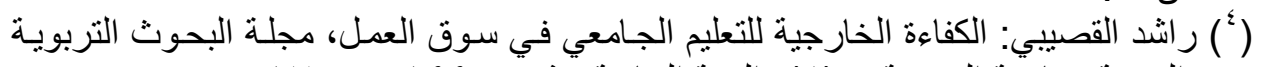

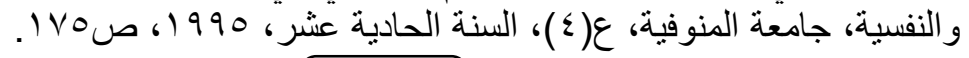




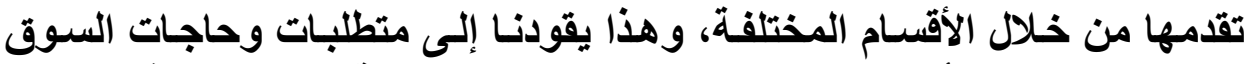

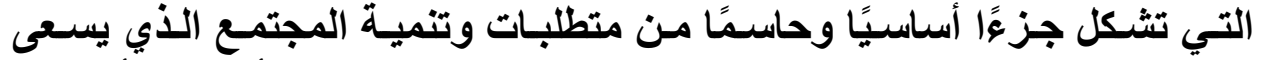

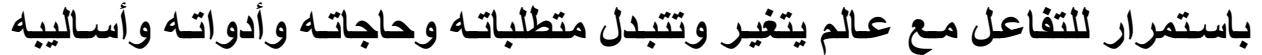
وآلياته بشكل متسارع (')

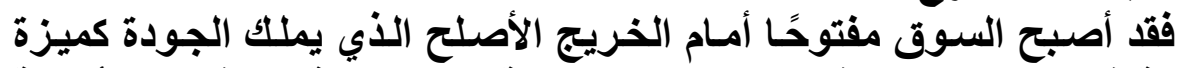

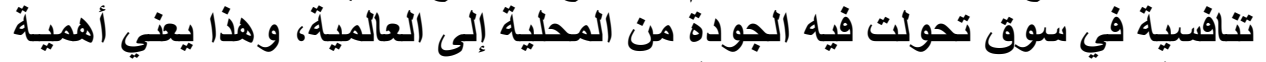

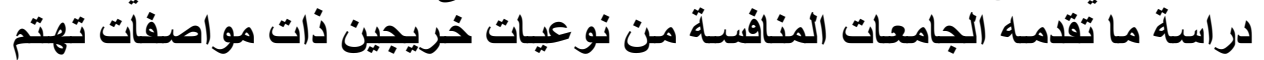

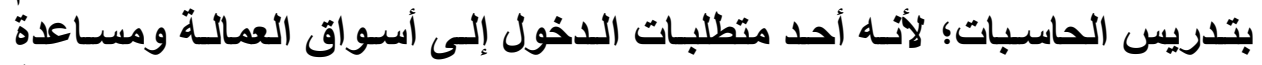

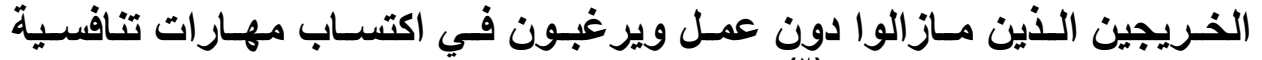

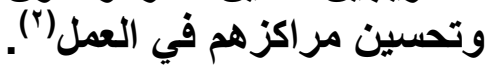

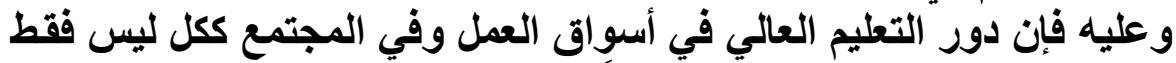

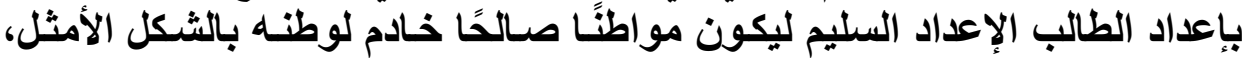

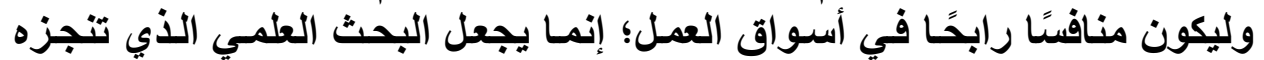

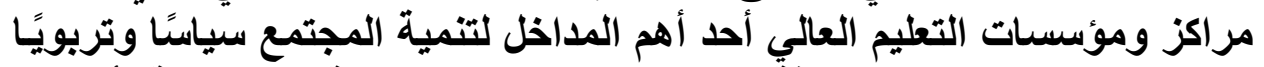

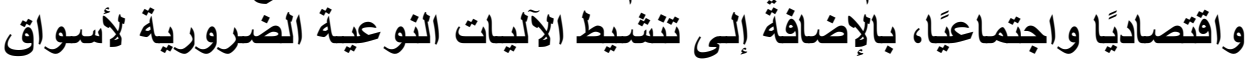

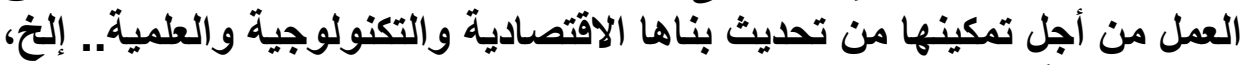

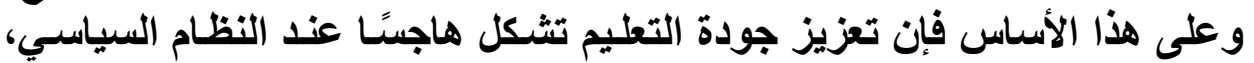

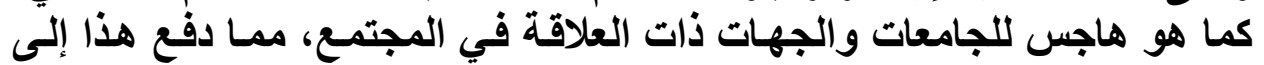

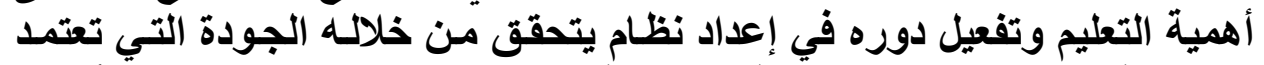

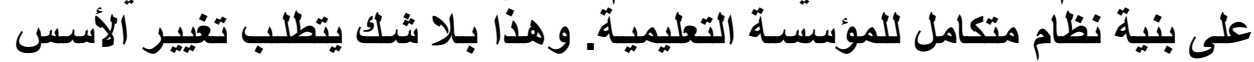

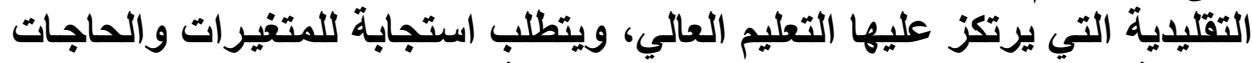

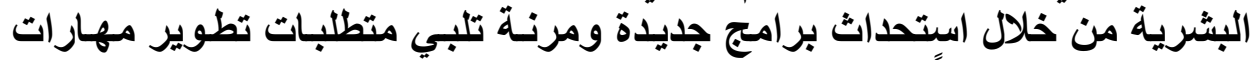

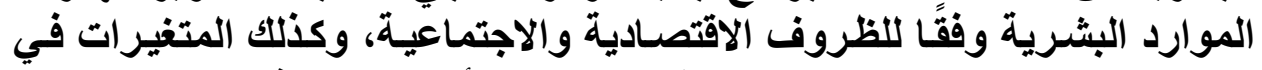

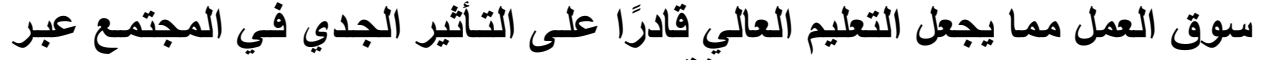

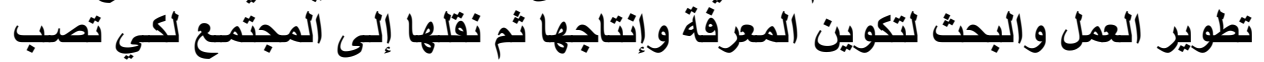

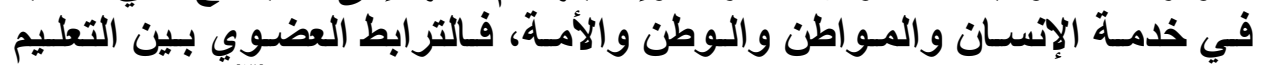

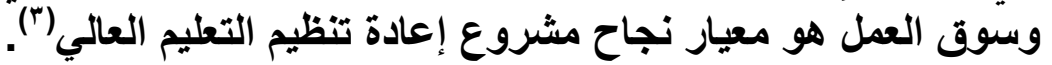

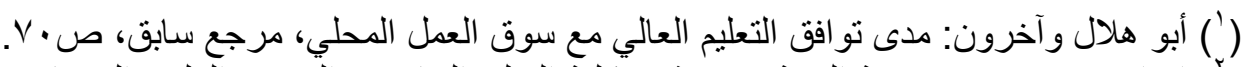

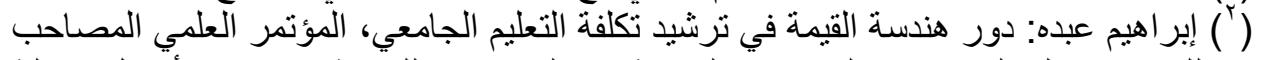

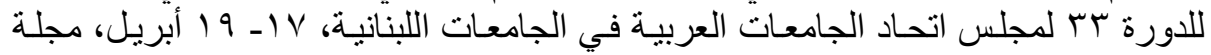

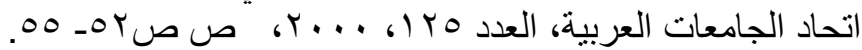

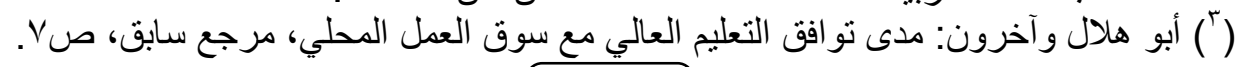


ثانيًا: الإطار المنهجيي البـهث:

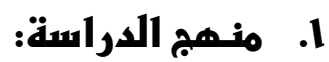

المنهج هو الطريق المؤدي إلى الكثف عن العن الحقيقة في العلوم بواسطة

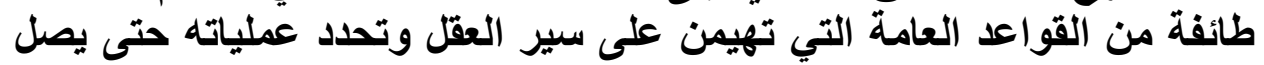

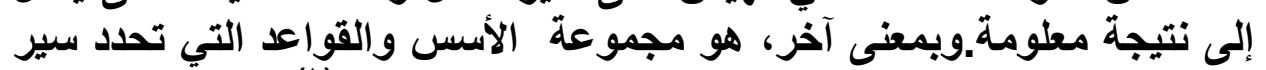

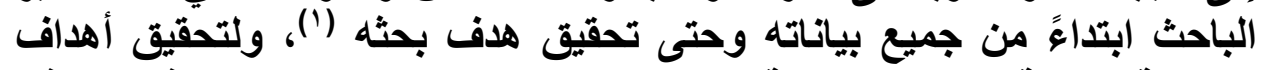

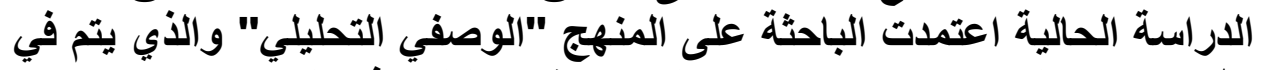

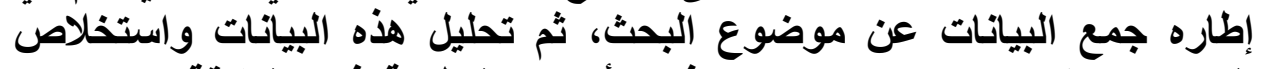

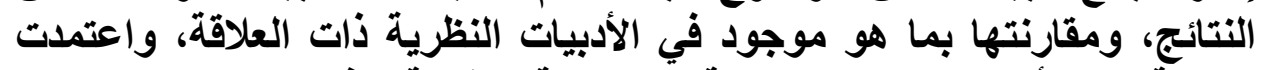

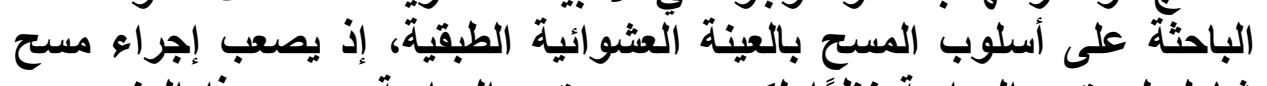

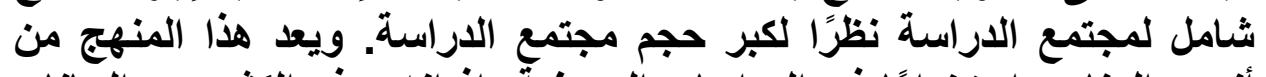

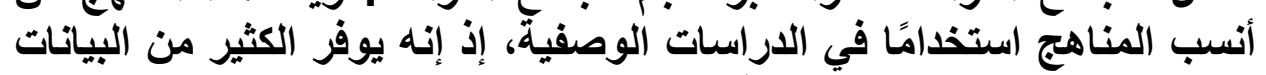
والمعلومات عن موضوع الدراسة.

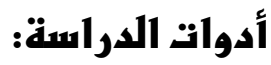

لتحقيق أهداف الاراسة، وجمع البياتات للإجابة على أسئلتها، تم إعداد الاداد

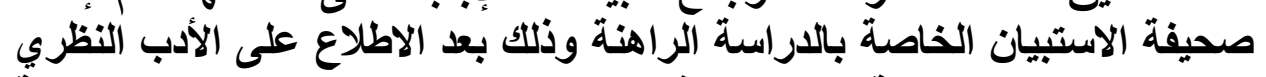

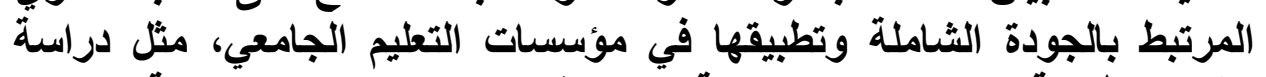

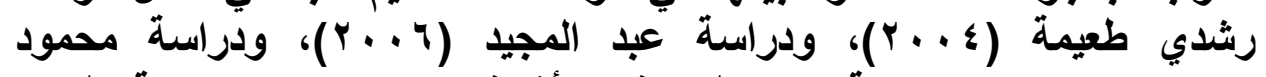

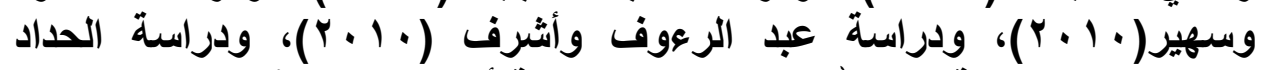

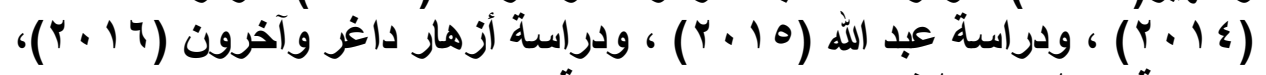

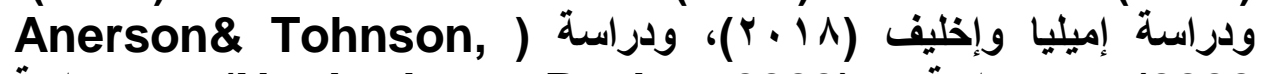

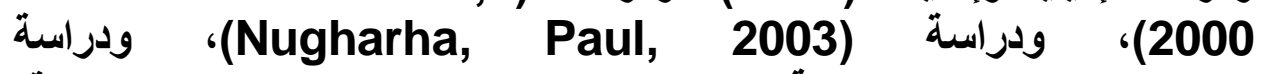

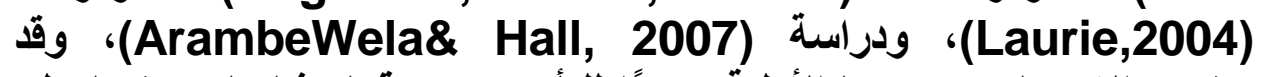

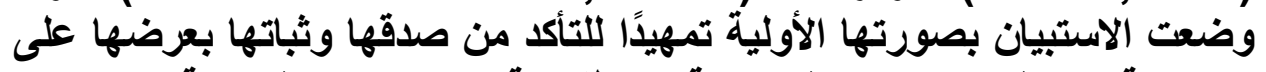

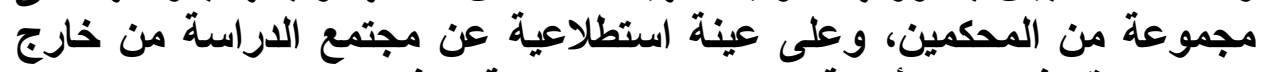

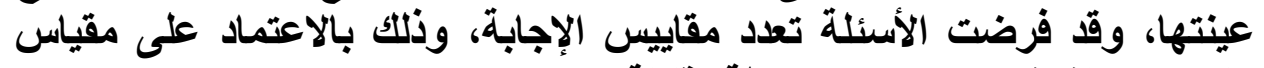

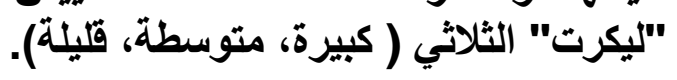

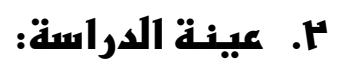
أجريت هذه الاراسة في أربع عينات:

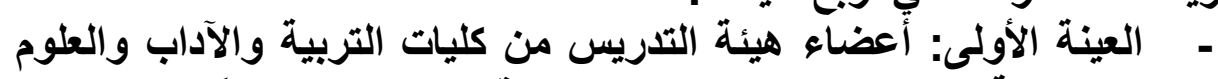

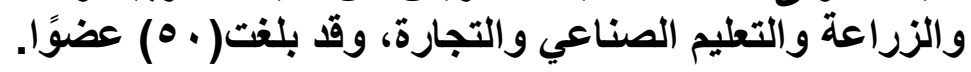

(') غريب سيد أحمد، عبدالباسط عبدالمعطي: البحث الاجتماعي- الدنهج و القياس، الجزء الأول،

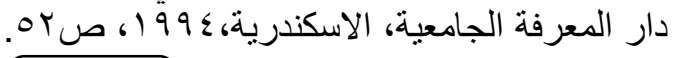
$\Lambda 1$ 


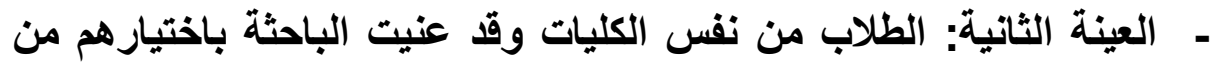

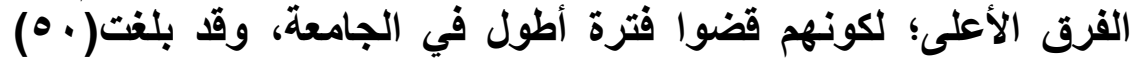
طالبًا. - العينة الثالثة: أفراد المجتمع من الإداريين والعاملين في الجامعة؛ لكونهم

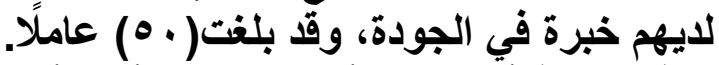

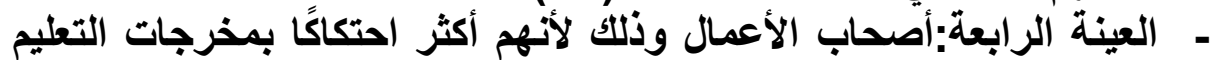

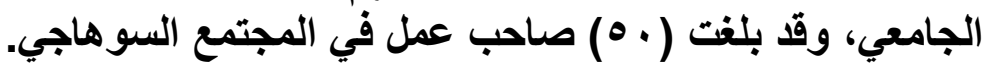

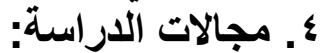

المجال الجغرافي(المكاني):ويقصد به المنطقة الجغرافية التي ستجرى عليها

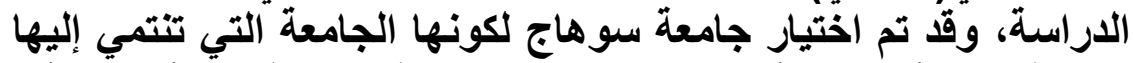

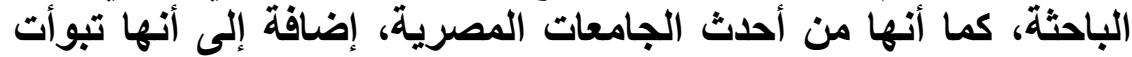

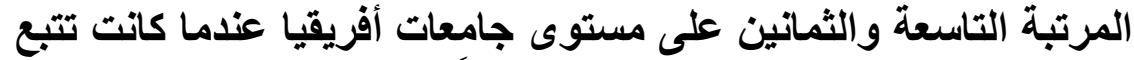

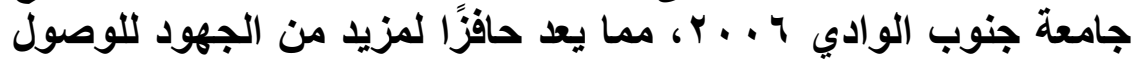

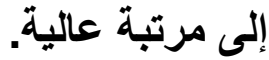

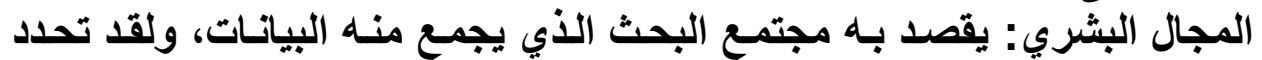
المجال البشرى، فئي أربع عينات:

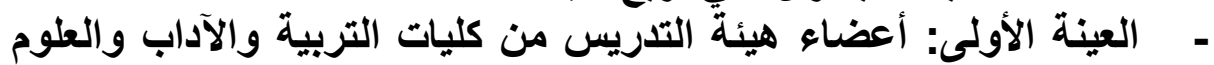

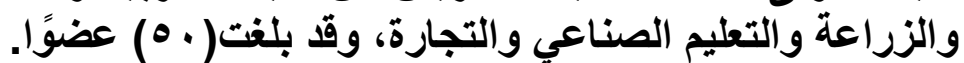

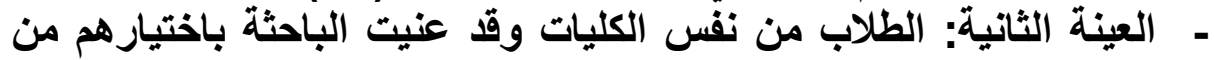

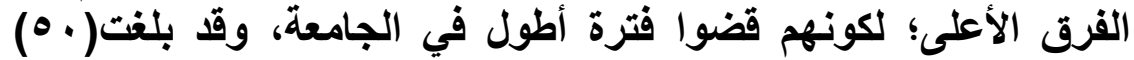

- - العينة الثالثة: أفراد المجتمع من الإداريين والعاملين في الجامعة؛ لكونهم

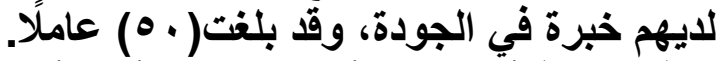
- العينة الرابعة:أصحاب الأعمال وذلتك لأنهم أكثر احتكائًا بمخرجات التعليم

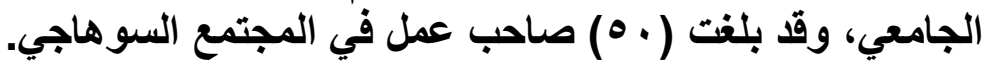

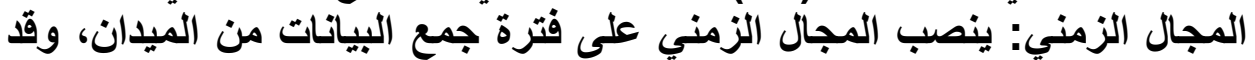

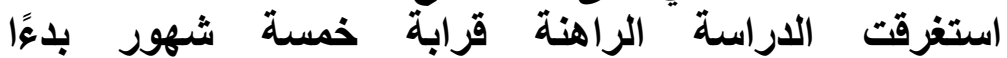

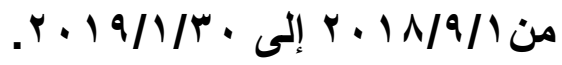




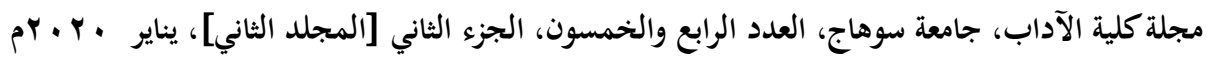

0.تصليل ببانات الدراسة وتنفسيرها:

الخصائص الاجتماعية لعينة أعضاء هيئة التدريس ومعاونيهم والطلاب.

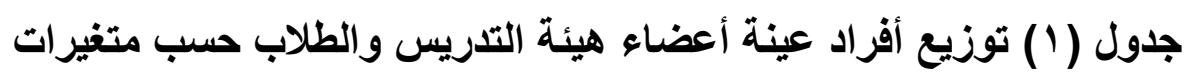

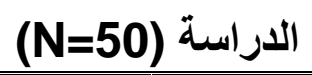

\begin{tabular}{|c|c|c|c|c|c|c|c|}
\hline \multicolumn{4}{|c|}{ عينة الطلاب } & \multicolumn{4}{|c|}{ أعضاء هيئة التدريس ومعاونيهج } \\
\hline$\%$ & ك & \multicolumn{2}{|c|}{ المتغــــــــــــيرات } & $\%$ & ك5 & \multicolumn{2}{|c|}{ المتغــــــــــــيرات } \\
\hline rr & 11 & ذكر & \multirow{2}{*}{ 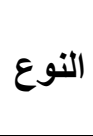 } & $\leqslant r$ & ri & ذكر & \multirow{2}{*}{ 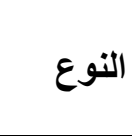 } \\
\hline$\vee \wedge$ & rq & أنثى & & $0 \wedge$ & rq & أنثى & \\
\hline$\wedge$. & $\varepsilon$. & علوم إنسانية & \multirow{2}{*}{ الكلية } & צ & rr & علوم إنساتية & \multirow{2}{*}{ التخصص } \\
\hline$r$. & 1. & علوم تطبيقية & & ד & 11 & علوم تطبيقية & \\
\hline$\wedge$ & $\varepsilon$ & من أقل من ـ ب سنة إلى & \multirow{4}{*}{ فئات } & $r$. & 1. & سنو 5 إلى أقل 10 & \multirow{4}{*}{ سنوات } \\
\hline $0 \leqslant$ & rV & 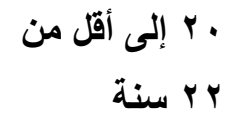 & & rr & 17 & 15 سنوات ألى من & \\
\hline rs & iv & 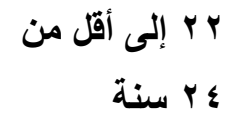 & & rs & 19 & 15 20 إلى أقل من & \\
\hline$\varepsilon$ & r & צ צ ب إلى أقل من & & 1. & 0 & 25 سنوات أقل من & \\
\hline & & & & 1 & $r$ & معيد & \multirow{5}{*}{ الرتبة } \\
\hline & & & & rs & ir & مدرس مساعد & \\
\hline & & & & rq & ir & مدرس & \\
\hline & & & & $\Gamma \varepsilon$ & IV & أستاذ مساعد & \\
\hline & & & & 1. & 0 & أستاذ & \\
\hline
\end{tabular}

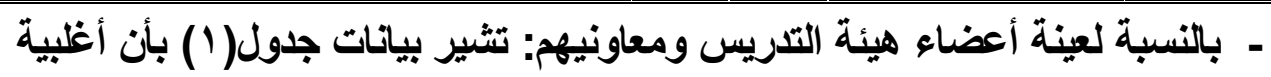

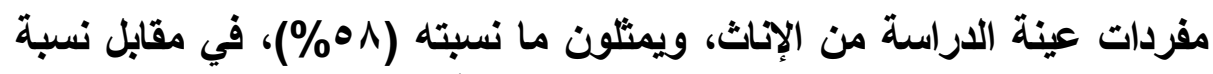

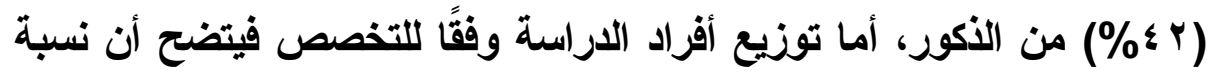

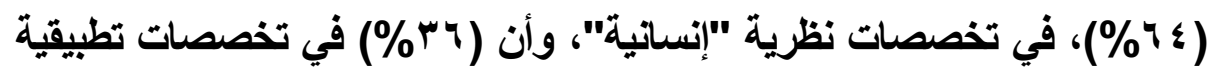


"عملية"، والسبب في ذلك أن الإقبال على الفرع الأدبي يكون أكثر من الإقبال على الفرع العلمي، أما توزيع عينة الدراسة حسب سنوات الخبرة، فيلاحظ أن ما نسبته

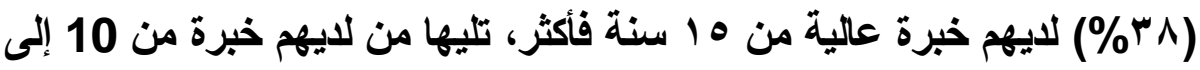

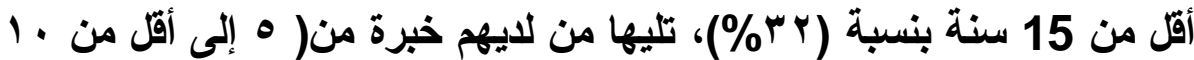

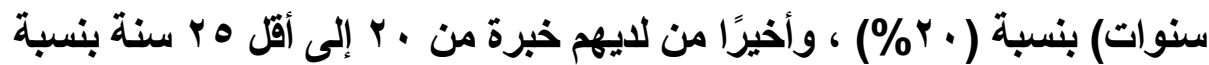

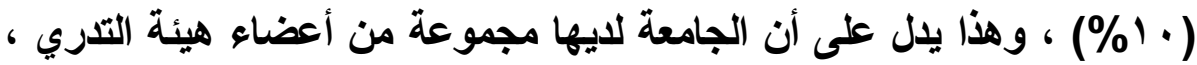

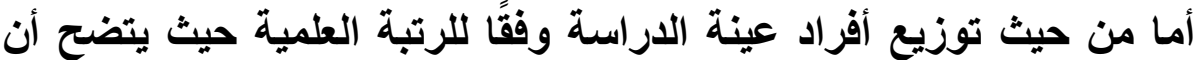

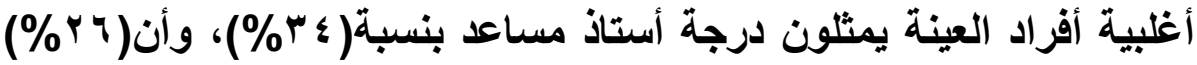

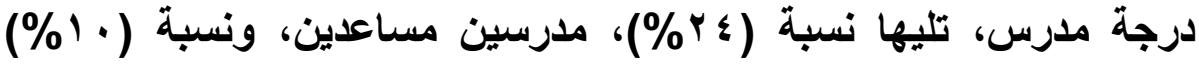

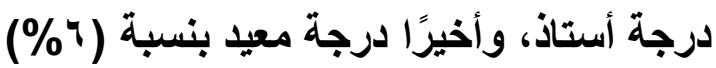

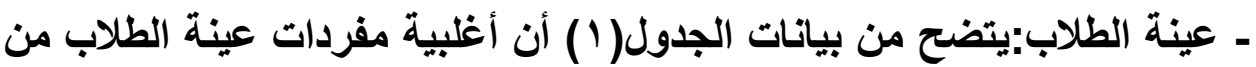

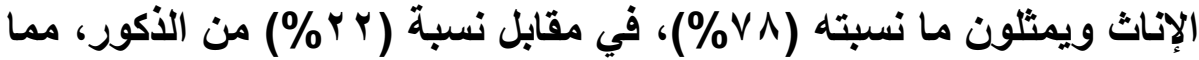

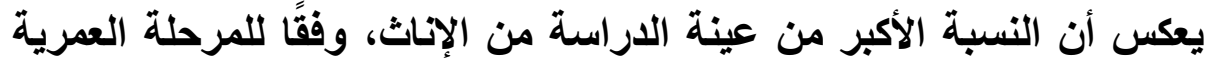

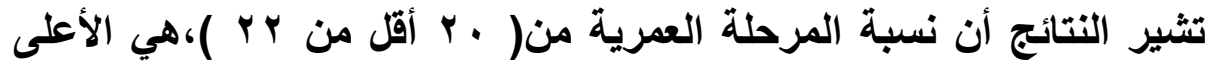

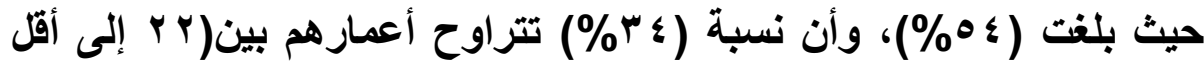

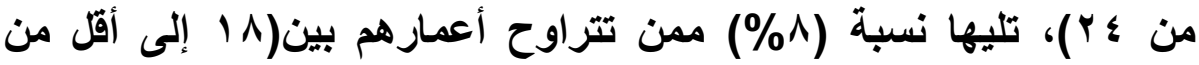
•r.

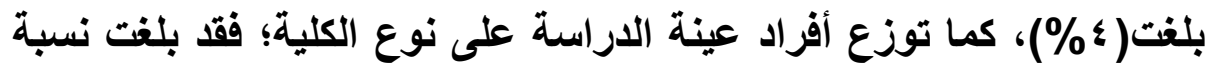
من هم في كليات إنسانية (•^\%)، بينما كانت نسبة العلوم التطبيقية $(\% r \cdot)$ 


\section{تلبية الجامعة لإهتياجات سوق العمل}

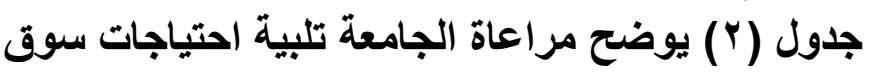
العمل من وجهة نظر أعضاء هيئة التدريس ومعاونيه آتئح

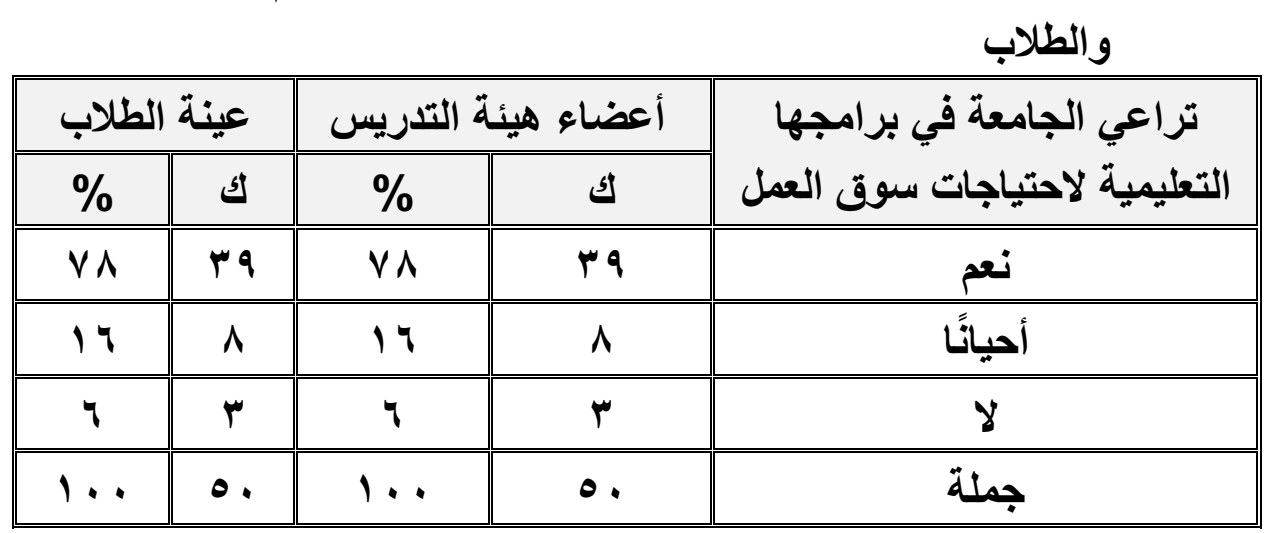

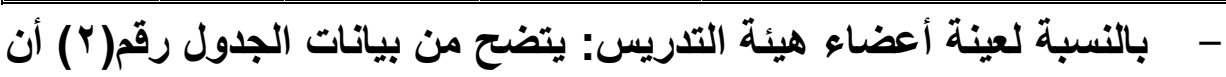

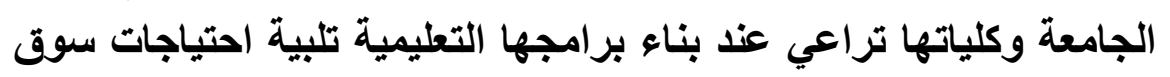

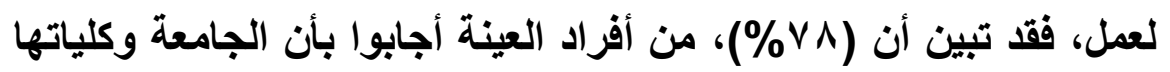

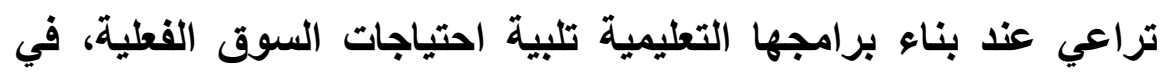

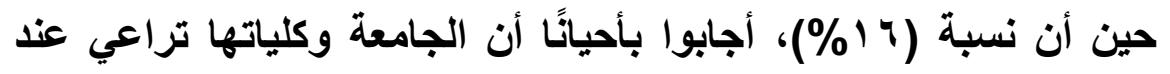

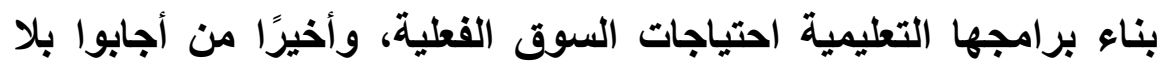
تمثلت نسبتهم(†\%) من إجابات أعضاء هيئة التدريس.

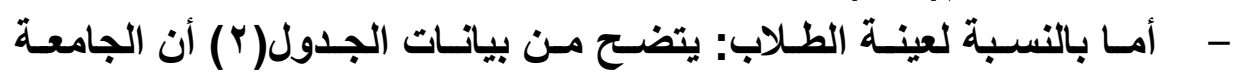

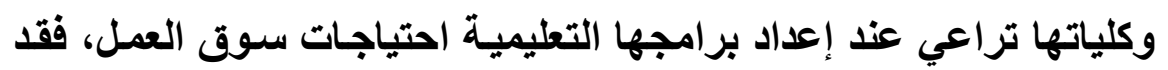

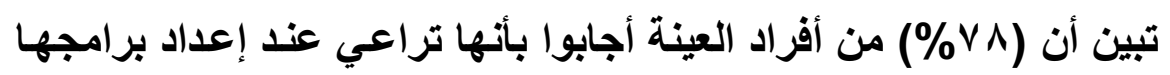

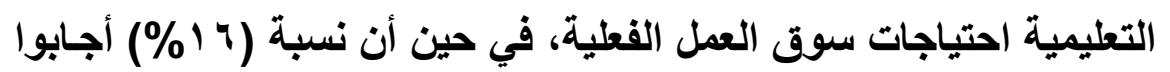

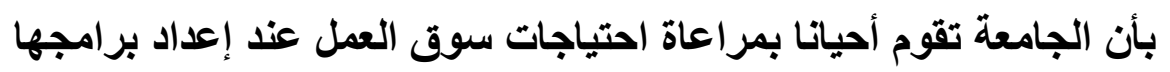

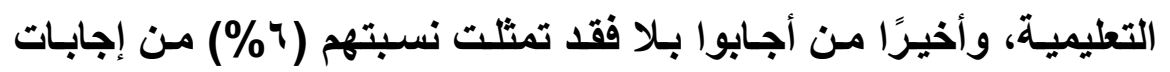

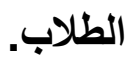




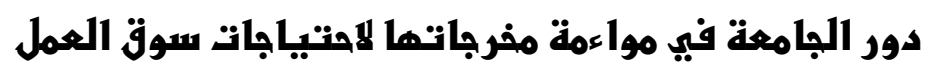
جدول رقم (ب) دور الجامعة وكلياتها فى مواءمة مخرجات سوق العمل من وجهة نظر أعضاء هيئة التدريس

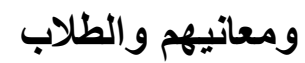

\begin{tabular}{|c|c|c|c|c|c|c|c|c|c|c|c|c|}
\hline \multicolumn{6}{|c|}{ عينة الطلاب } & \multicolumn{6}{|c|}{ أعضاء هيئة التدريس } & \multirow{3}{*}{ 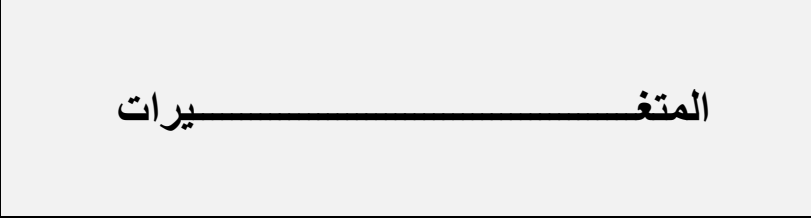 } \\
\hline \multicolumn{2}{|c|}{ قليلة } & \multicolumn{2}{|c|}{ متوسطة } & \multicolumn{2}{|c|}{ كبيرة } & \multicolumn{2}{|c|}{ قليلة } & \multicolumn{2}{|c|}{ متوسطة } & \multicolumn{2}{|c|}{ كبيرة } & \\
\hline$\%$ & كs & $\%$ & 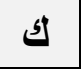 & $\%$ & كs & $\%$ & ك5 & $\%$ & كs & $\%$ & كs & \\
\hline 7 & $r$ & r. & 10 & $7 \varepsilon$ & rr & 7 & $r$ & $r$. & 10 & $7 \varepsilon$ & rr & تشتحة المجتمع وسامعة التخصص العملت العلمية تتلائم مع \\
\hline 1 . & $\bullet$ & $\leq 7$ & rM & $\varepsilon \varepsilon$ & rr & ir & 7 & Y & ri & $\leqslant 7$ & r & توزيع الطلاب بين التخصصات بحسب متطلبات \\
\hline$Y \varepsilon$ & ir & $r \varepsilon$ & ir & or & rq & ir & 7 & $\leqslant \varepsilon$ & rr & $\varepsilon \varepsilon$ & rr & إثراك قطاع العمل في تحديد سياسة القبول. \\
\hline$Y \xi$ & Ir & Y & IT & 0 . & ro & 1. & 0 & $\varepsilon Y$ & YI & $\leqslant \wedge$ & $r \varepsilon$ & تطوير المناهج بحسب حاجة سوق العمل. \\
\hline r & ir & $\mu$ & 10 & $\varepsilon \varepsilon$ & rr & $1 \leq$ & V & ○. & ro & rq & 11 & تنمية القدرة على الإبداع والابتكار. \\
\hline 17 & $\wedge$ & r. & 1. & $7 \varepsilon$ & rr & $r \leq$ & Ir & Tr & 17 & $\leqslant \varepsilon$ & rr & تحرص الجداف مؤسسات سلى توعية طلابها بأهدافها \\
\hline 7 & $r$ & rᄉ & $1 \leqslant$ & 97 & $r r$ & $r \cdot$ & 1 . & $r \varepsilon$ & ir & 09 & rᄉ & سوق العمل قبيرل الطلاب بالجامعة تتناسب مع احتياجات \\
\hline & & & & & & & & & & 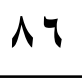 & & \\
\hline
\end{tabular}




\begin{tabular}{|c|c|c|c|c|c|c|c|c|c|c|c|c|}
\hline \multicolumn{6}{|c|}{ عينة الطلاب } & \multicolumn{6}{|c|}{ أعضاء هيئة التدريس } & \multirow{3}{*}{ 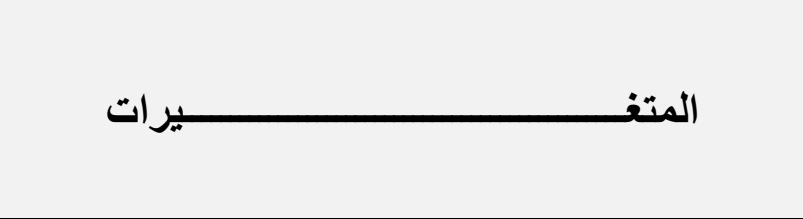 } \\
\hline \multicolumn{2}{|c|}{ قليلة } & \multicolumn{2}{|c|}{ متوسطة } & \multicolumn{2}{|c|}{ كبيرة } & \multicolumn{2}{|c|}{ قليلة } & \multicolumn{2}{|c|}{ متوسطة } & \multicolumn{2}{|c|}{ 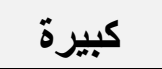 } & \\
\hline$\%$ & ك5 & $\%$ & كs & $\%$ & ك & $\%$ & ك5 & $\%$ & كs & $\%$ & ك & \\
\hline$\varepsilon$ & r & ir & 7 & $\Lambda \varepsilon$ & $\varepsilon r$ & $\varepsilon$ & r & 11 & 9 & $\vee \wedge$ & rq & تتسأهيل طلبتهامعة في مواقع مؤسسات سوق العمل لتدريب \\
\hline 7 & $r$ & r. & 1. & $V \varepsilon$ & rv & 17 & $\Lambda$ & rr & 17 & or & rq & تستخلم مؤسسات سوق العمل المحلي مقدرات \\
\hline 1 . & $\bullet$ & $r \cdot$ & 1 . & v. & ro & $\Lambda$ & $\varepsilon$ & $r \varepsilon$ & iv & $\Delta \wedge$ & rq & تسطعى الجامعة لتطبيق معايير الجودة التي تناسب \\
\hline r & 1 & rr & 11 & $V_{7}$ & $\wedge$ & $\varepsilon$ & $r$ & 11 & 9 & $\vee \wedge$ & rq & تعقد الجامعة ندوات وورش عمل حول احتياجات \\
\hline 7 & $r$ & r. & 10 & צ & $r Y$ & $\varepsilon$ & $r$ & r. & 10 & 79 & r & 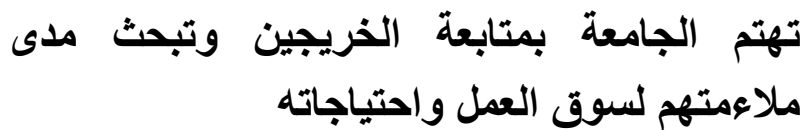 \\
\hline
\end{tabular}




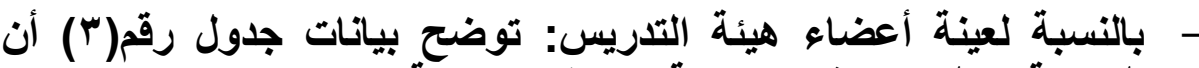

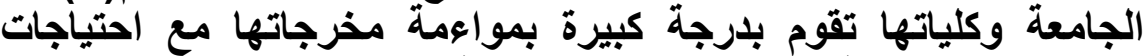

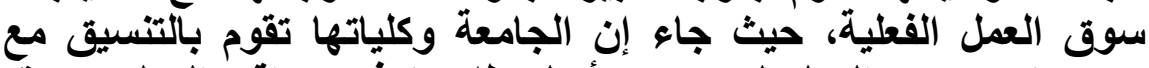

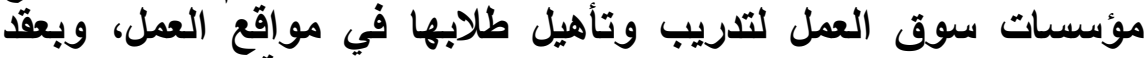

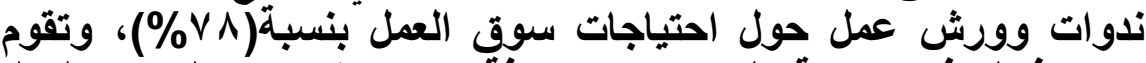

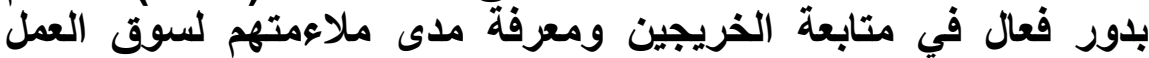

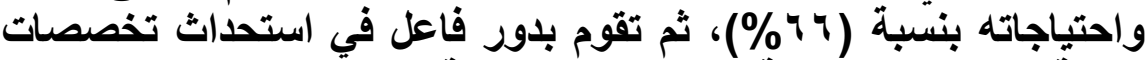

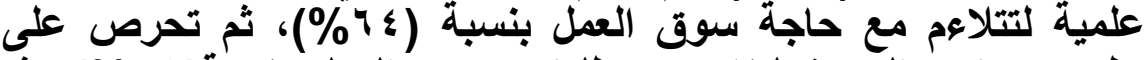

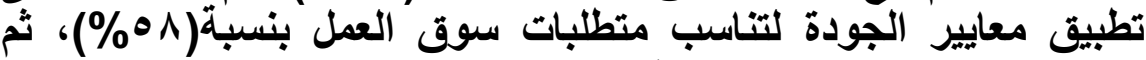

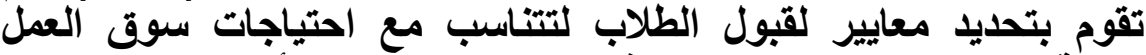

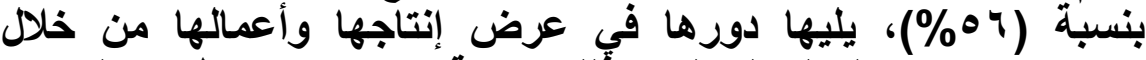

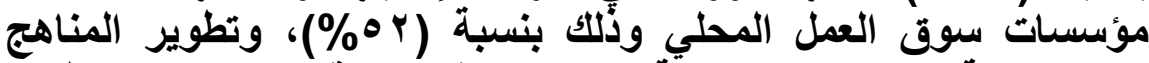

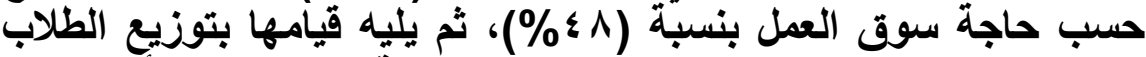

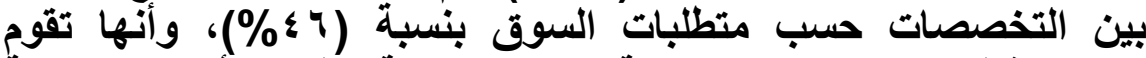

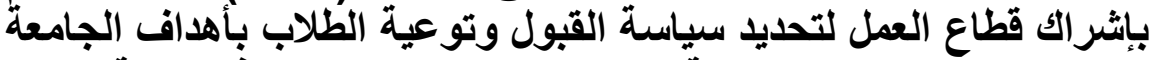

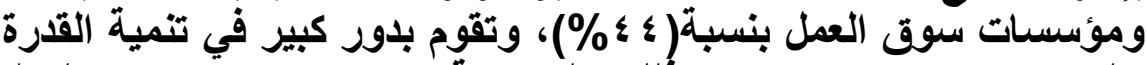

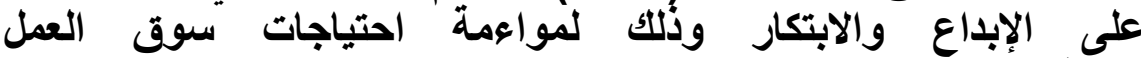

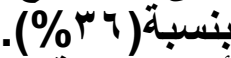
- أما بالنسبة لعينة الطلاب: يتبين من بيانات الجدول(با)، أن الجامعة

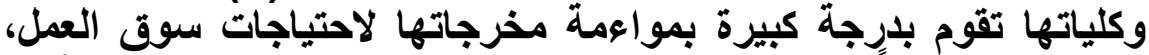

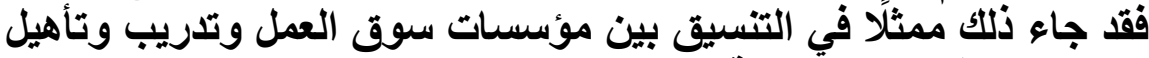

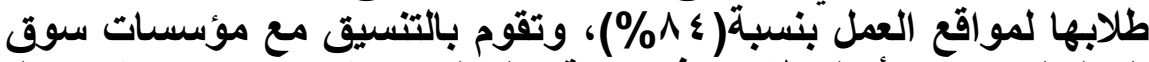

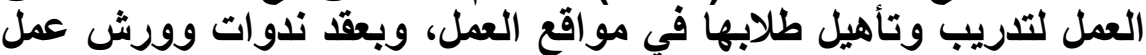

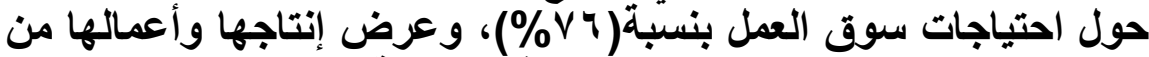

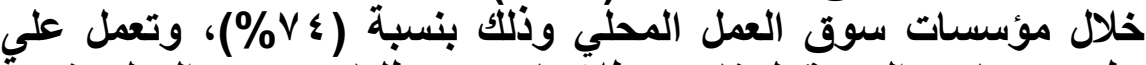

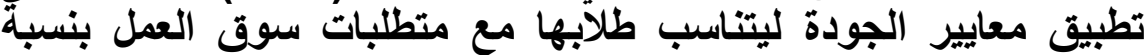

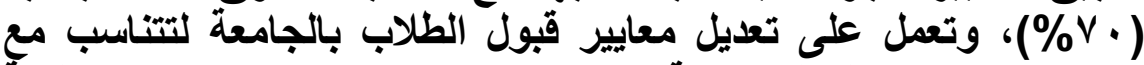

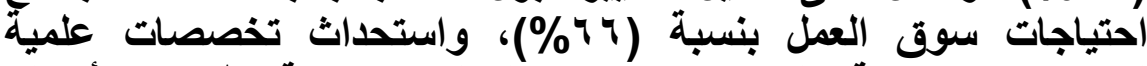

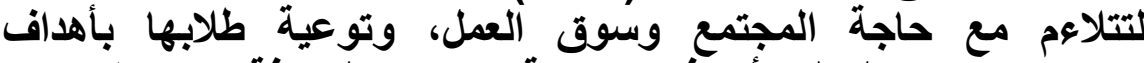

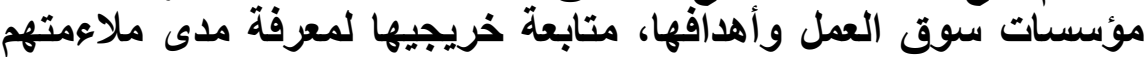

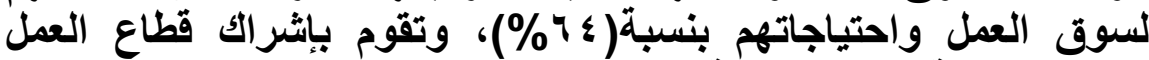

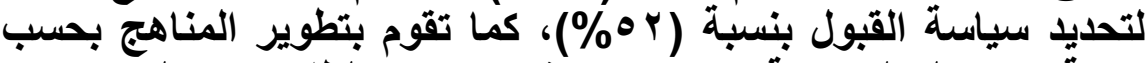

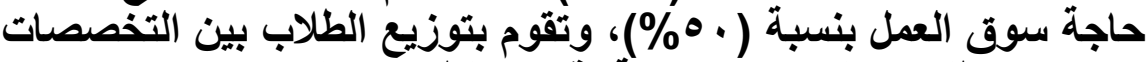
بحسب متطلبات السوق، وتنمية قدرة الطلاب على الإبداع والابتكار بنسبة ( \& \&\%). 
مناقثة نتائج سؤال "ما أهم المعوقات التي تحول دون تطبيق نظام الجودة من وجهة نظر أعضاء هيئة التنريس ومعاونيهم والطلاب؟

جدول رقم (؛) يوضح أهم المعوقات التي تحول دون تطبيق نظام الجودة من وجهة نظر أعضاء هيئة التدريس ومعاونيهم والطلاب

\begin{tabular}{|c|c|c|c|c|c|c|c|c|c|c|c|c|}
\hline \multicolumn{6}{|c|}{ عينة الطلاب } & \multicolumn{6}{|c|}{ أعضاء هيئة التدريس } & \multirow{3}{*}{ 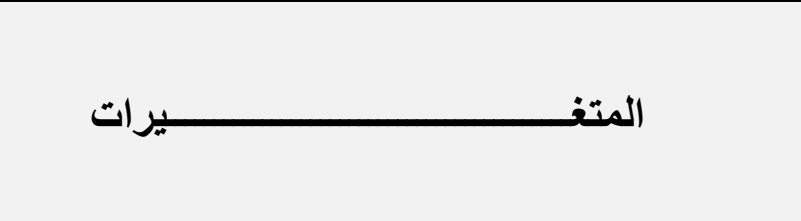 } \\
\hline \multicolumn{2}{|c|}{ 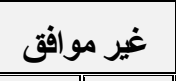 } & \multicolumn{2}{|c|}{ موافق } & \multicolumn{2}{|c|}{ موافق بشدة } & \multicolumn{2}{|c|}{ غير موافق } & \multicolumn{2}{|c|}{ موافق } & \multicolumn{2}{|c|}{ موافق بثدة } & \\
\hline$\%$ & ك & $\%$ & ك & $\%$ & s & $\%$ & s & $\%$ & ك & $\%$ & ك & \\
\hline . & . & . & . & - & . & $\wedge$ & $\varepsilon$ & r. & 1. & vr & rq & عدم قتاعة القيادات الأكاديمية بتطبيق الجودة \\
\hline . & . & . & . & - & . & 11 & 9 & צו & ir & 09 & is & غموض معايير اختيار القيادات الأكاديمية \\
\hline r. & 1. & $r$. & 10 & o. & ro & 1 & $r$ & ir & 1 & Ar & $\leqslant 1$ & الكثافة الطلابية داخل بعض الكليات \\
\hline . & . & . & . & - & . & $r \leq$ & ir & r. & 1. & 09 & ru & ضعف الحوافز المعنوية \\
\hline . & - & . & . & - & . & in & 9 & rᄉ & 19 & $\leq \varepsilon$ & ri & ضعف الحوافز المادية \\
\hline 7 & $r$ & r. & 1. & $v \leqslant$ & rv & r. & 1. & $r \leq$ & ir & 09 & rA & الافتقار لظروف عمل مناسبة \\
\hline . & . & . & . & - & . & $\varepsilon$ & r & $r$. & 10 & 74 & rr & قلة مشاركة أعضاء هيئة التلريس في الجواتب الإدارية \\
\hline$Y \varepsilon$ & IT & $\varepsilon$. & $r$. & T & 11 & $\varepsilon$ & r & 17 & $\wedge$ & A. & 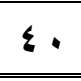 & قلة الاعتماد على العمل الجماعي \\
\hline 1. & 0 & $\leqslant 4$ & $r \mu$ & $\{\leqslant$ & TY & 7 & $\bar{r}$ & $r \varepsilon$ & Ir & $v$. & ro & غلبة طابع الإجراءات الروتينية والبيروقراطية. \\
\hline
\end{tabular}




\begin{tabular}{|c|c|c|c|c|c|c|c|c|c|c|c|c|}
\hline \multicolumn{6}{|c|}{ عينة الطلاب } & \multicolumn{6}{|c|}{ أعضاء هيئة التدريس } & \multirow{3}{*}{ 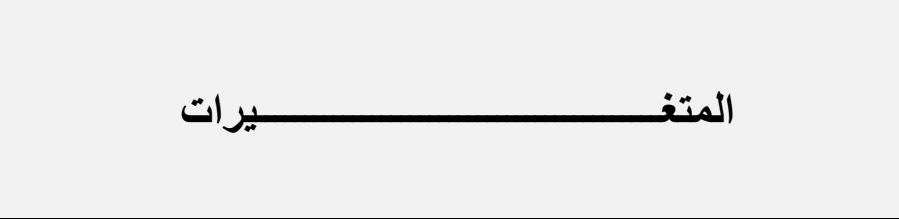 } \\
\hline \multicolumn{2}{|c|}{ 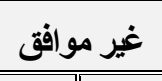 } & \multicolumn{2}{|c|}{ موافق } & \multicolumn{2}{|c|}{ موافق بثدة } & \multicolumn{2}{|c|}{ غير موافق } & \multicolumn{2}{|c|}{ موافق } & \multicolumn{2}{|c|}{ موافق بشدة } & \\
\hline$\%$ & ك & $\%$ & ك5 & $\%$ & ك & $\%$ & ك & $\%$ & ك & $\%$ & ك & \\
\hline 17 & $\wedge$ & $\varepsilon \wedge$ & $r \varepsilon$ & rq & 11 & 1 . & $\bullet$ & $r \cdot$ & 1. & v. & טه & الاعتماد على إيصال المعرفة عن الطرق التقليدية والتلقين \\
\hline 11 & 9 & $\varepsilon \wedge$ & r $\varepsilon$ & $r \varepsilon$ & iv & rq & 11 & $r \cdot$ & 1. & $\varepsilon \varepsilon$ & rr & الافتقار إلى آليات لتنمية سلوكيات المعرفة لاى الأشخاص \\
\hline $1 \varepsilon$ & $\mathrm{v}$ & $\leqslant 7$ & $r$ & $\varepsilon$. & r. & $r \cdot$ & 1 . & r. & 10 & $\bullet$. & ro & ضعف العلاقة بين الجامعة وسوق العمل \\
\hline rr & 11 & $r$. & 10 & $\varepsilon \wedge$ & Y $\varepsilon$ & rq & Ir & $r \varepsilon$ & iv & $\varepsilon$. & $r \cdot$ & الافتقار إلى آليات تلتمس مشكلات المجتمع \\
\hline 7 & $r$ & ir & 7 & $\Lambda r$ & $\leqslant 1$ & $\varepsilon$ & r & 17 & $\wedge$ & $\Lambda$. & $\varepsilon$. & مقاومة التغيير \\
\hline- & - & - & - & - & - & 1. & $\bullet$ & r^ & $1 \leqslant$ & 74 & r & الخوف من كل ما هو جديد \\
\hline 7 & $r$ & Ir & 7 & $\Lambda r$ & $\leqslant 1$ & 17 & $\Lambda$ & $\leqslant \Lambda$ & $Y \varepsilon$ & rq & 11 & ضعف الوعي بأهمية تطبيق نظام الجودة. \\
\hline$\Lambda$ & $\varepsilon$ & r. & 10 & Tr & r & 11 & 9 & $\leqslant \Lambda$ & $Y \varepsilon$ & & IV & وأساليب وجود روية واضحة لدى الجميع عن مفاهيم الجودة \\
\hline$r$. & 1. & $Y \leq$ & Ir & 07 & rA & $1 \varepsilon$ & V & $\leq 7$ & $r r$ & $\varepsilon$. & $r$. & مبادئ- أفكار) إحاث التغيير المطلوب في ثقافة الجامعة(قيم - \\
\hline$r \varepsilon$ & iv & q & 11 & r. & 10 & $\varepsilon$ & r & Ir & 7 & $\Lambda \varepsilon$ & $\varepsilon r$ & المركزية في صنع السياسات التطليمية واتخاذ القرارات \\
\hline
\end{tabular}




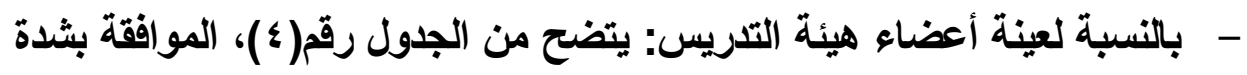

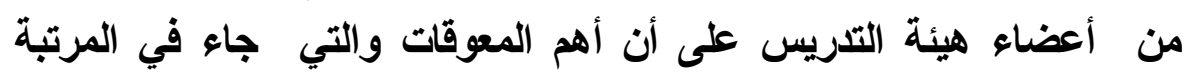

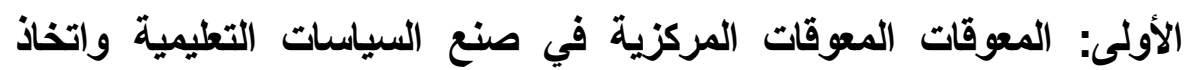

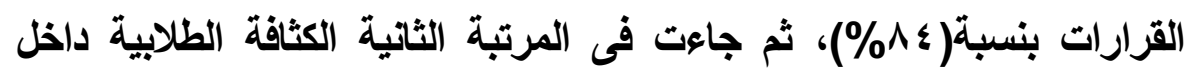

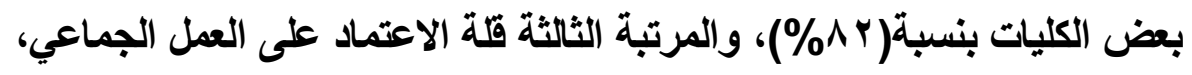

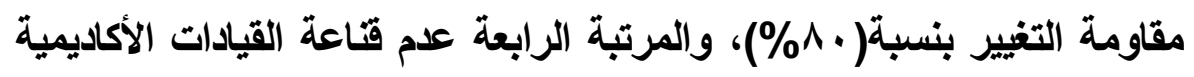

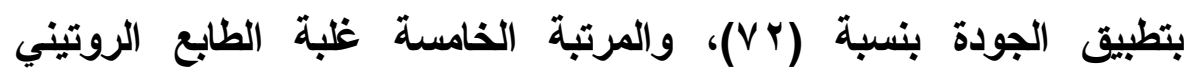

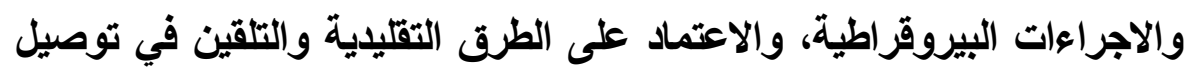

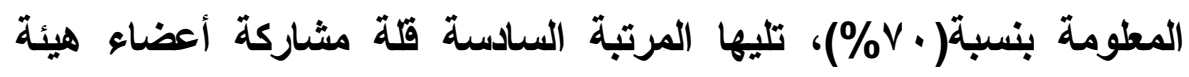

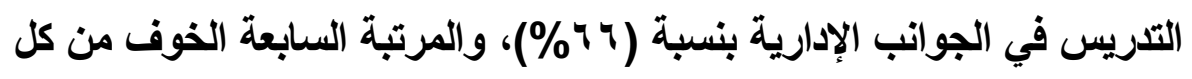

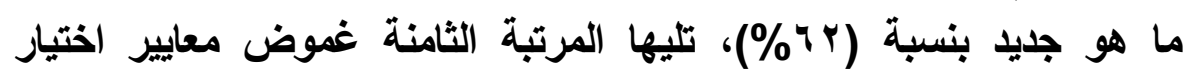

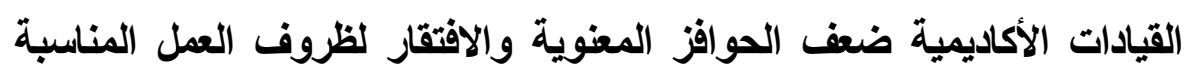

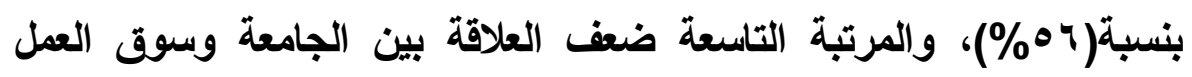

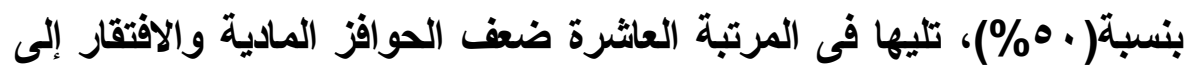

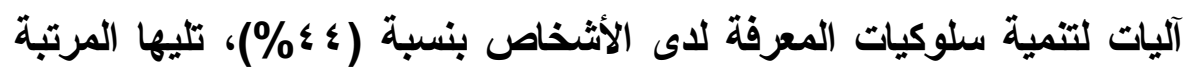

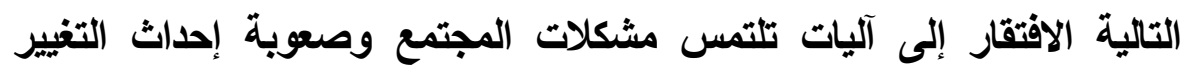

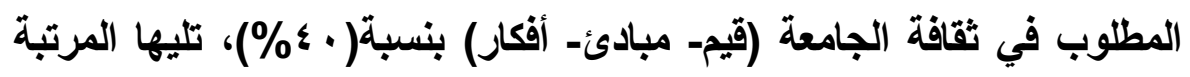

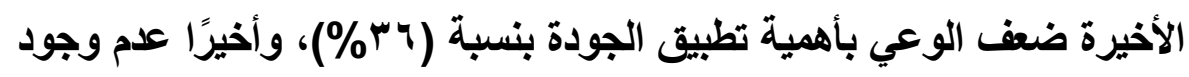

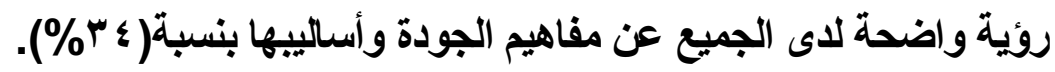

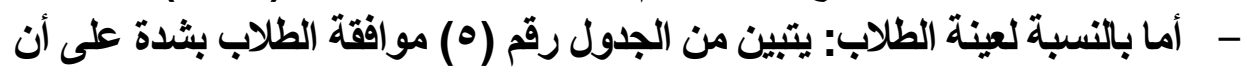

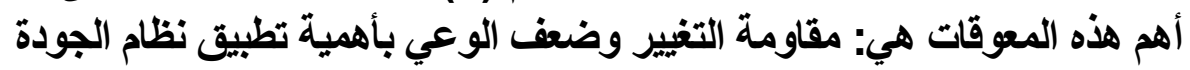

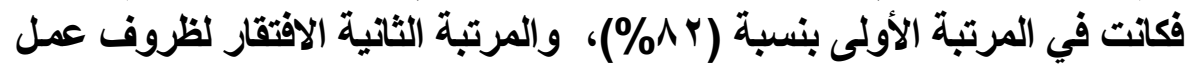

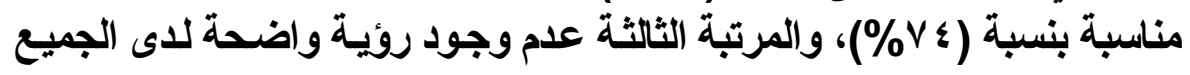

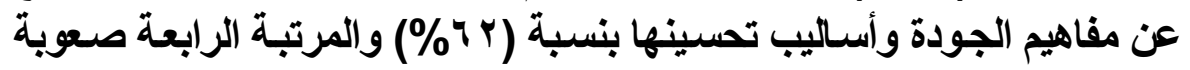

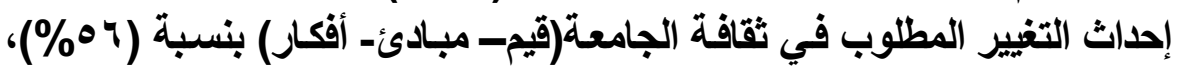

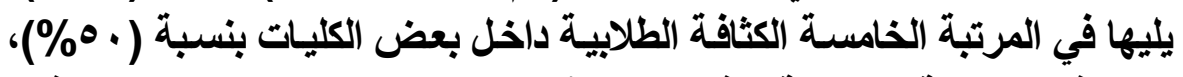

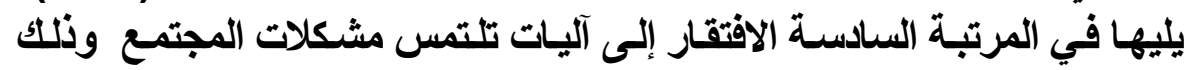

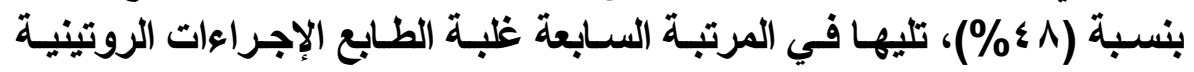

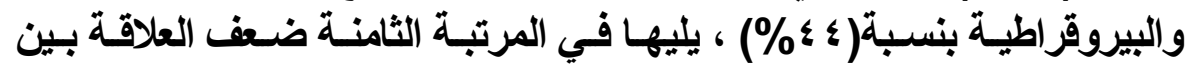




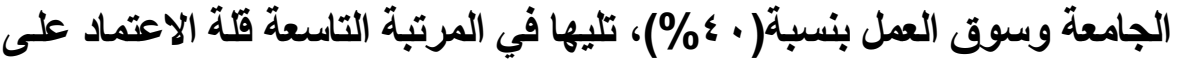

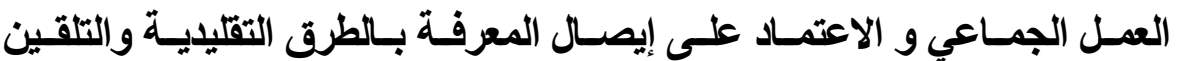

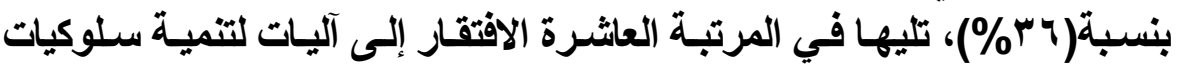

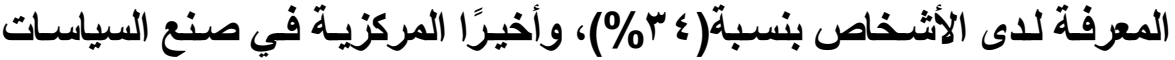

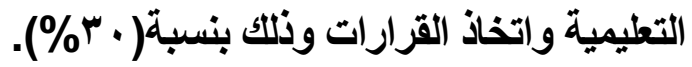
وتتفق هذه النتيجة مع دراسة(Ft.Al.2010, (Finch) بعنوان" تغيير ثقافة الكليات والجامعات لجعها أكثر قرة على درة التكيف" والتي توصلت إلي ضرورة إزالة التهو

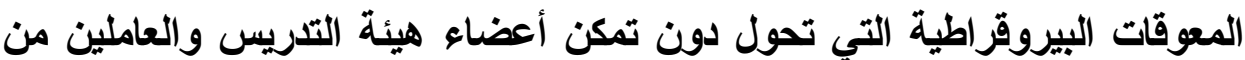
القيام بواجباتهم على الوجه الأكمل في تطبيق الجودة في المؤسسات التعليمية'(').

الخصائص الاجتماعية لعينة أفراد المجتمع من الإداريين والعاملين بالجامعة وأصحاب الأعمال

جدول(0) يوضح توزيع الأفراد الإداريين والعاملين بالجامعة

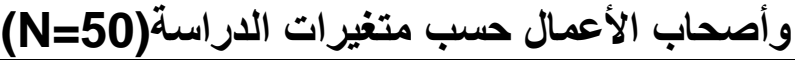

\begin{tabular}{|c|c|c|c|c|}
\hline \multicolumn{2}{|c|}{ أصحاب الأعمال } & \multicolumn{2}{|c|}{ وأفراد المجتمع من الإداريين } & \multirow[t]{2}{*}{ النوع } \\
\hline$\%$ & ك5 & $\%$ & ك5 & \\
\hline 7. & . & $O Y$ & $r y$ & ذكور \\
\hline$\varepsilon$. & $r$. & $\varepsilon \Lambda$ & $Y \varepsilon$ & إناث \\
\hline 0 . & 0. & $1 \ldots$ & 0. & جملة \\
\hline
\end{tabular}

بالنسبة لعينة أفراد المجتمع من الإدرايين والعاملين بالجامعة، يتضح من بيانات

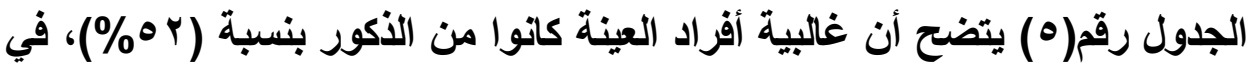

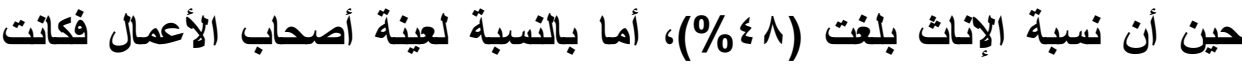

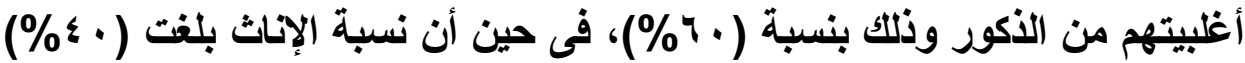
من جملة أصحاب الأعمال.

(1) Finchm, Aikyna, et.al, "changing the culture of colleges and universities to make them more adaptive", Intellect Base International Consortium,vol.3,No (7) ,2010,pp.40-53. 
جدول رقم (T) العوامل التي تسهم في علم توافق مخرجات التعليم العالي مع منطلبات سوق العمل

\begin{tabular}{|c|c|c|c|c|c|c|c|c|c|c|c|c|}
\hline \multicolumn{6}{|c|}{ أصحاب الأعمال } & \multicolumn{6}{|c|}{ الأفراد الإداريين و العاملين بالجامعة } & \multirow[t]{3}{*}{ المتغيرات } \\
\hline \multicolumn{2}{|c|}{ قليلة } & \multicolumn{2}{|c|}{ متوسطة } & \multicolumn{2}{|c|}{ كبيرة } & \multicolumn{2}{|c|}{ قليلة } & \multicolumn{2}{|c|}{ متوسطة } & \multicolumn{2}{|c|}{ كبيرة } & \\
\hline$\%$ & s & $\%$ & ك & $\%$ & ك & $\%$ & ك & $\%$ & كs & $\%$ & ك & \\
\hline 7 & $r$ & rr & 11 & Vr & m & ir & 7 & rr & 14 & 04 & r & عدم توزيع الطلاب بين التخصصات بحسب متطلبات السوق. \\
\hline r & 1 & rᄉ & 19 & $\because$. & $r$. & 1. & ० & « & r) & « & $r \varepsilon$ & عدم إشراك قطاع العمل في تحديد سياسة القبول. \\
\hline$\varepsilon$ & r & $r \varepsilon$ & ir & vr & rq & $r \varepsilon$ & ir & r4 & 14 & 0. & ro & علدم تطوير المناهج بحسب حاجة سوق العمل. \\
\hline $1 \varepsilon$ & $\mathrm{v}$ & Or & r & $\mu \varepsilon$ & IV & $1 \leq$ & $\mathrm{v}$ & $\leq 7$ & r & $\varepsilon$. & r. & عدم تمية الققرة طلى الإبداع والابتكار. \\
\hline
\end{tabular}

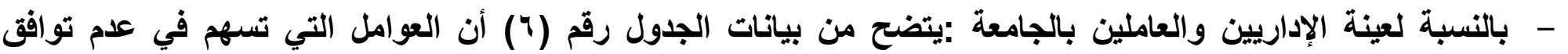

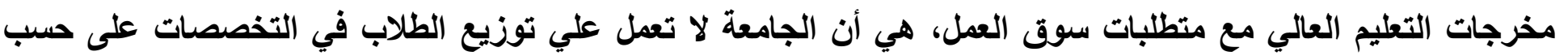

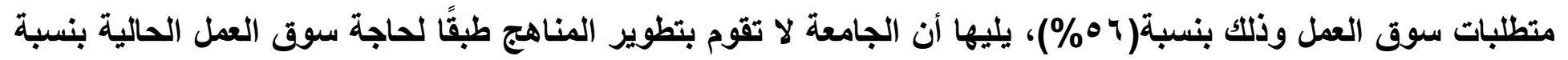

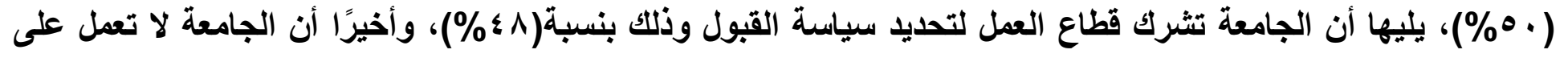
تنمية القارة على الإبداع والابتكار لاى طلابها وذلك بنسبة ( • ؛ \%). 
تطبيق نظام الجودة في التعليم الجامعي وتأثيره على مخرجات سوق العمل

- بالنسبة لأصحاب الأعمال: يرى أصحاب الأعمال من خلال الجدول السابق أن

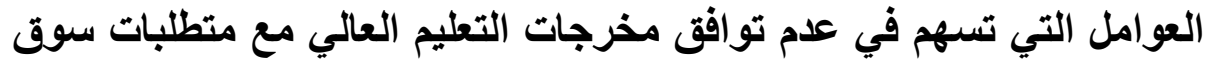
العمل عدم توزيع الطلاب بين التخصصات بحسب منطلبات السوق، وعدم

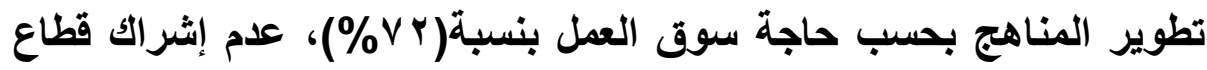
العمل في تحديد سياسة القبول بنسبة ( •\%\%)، ثم يليها عدم تنمية القدرة على الإبداع والابتكار لاى الطالب بنسبة (ع عـ\%).

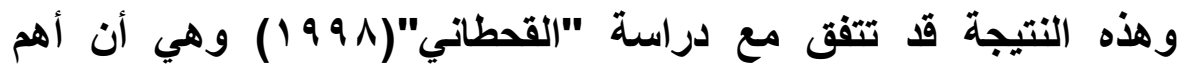

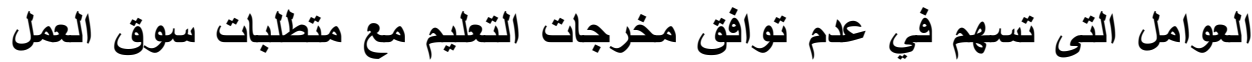
هي: عدم توزيع الطلاب بين التخصصات حسب متطلبات السوق، وعدم تطوير المناهج حسب حاجة السوق، والاعتماد على أسلوب التلقين، وعدم تتمية القدرة

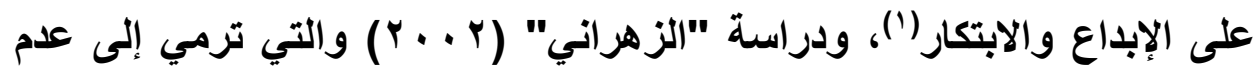
وجود قواعد معلومات عن احتياجات سوق العمل من التخصصات والمهارات

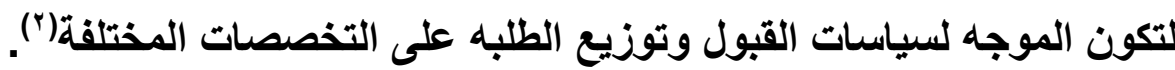
.احتياجات التعليم الجامعي لتلبية متطلبات سوق العمل من وجهة نظر الإداريين والعاملين

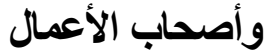

(1) سالم بن سعيد القحطاني: مدى ملائمة مخرجات التعليم العالي لمتطلبات سوق العمل في

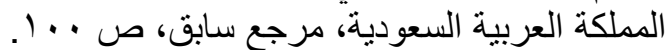

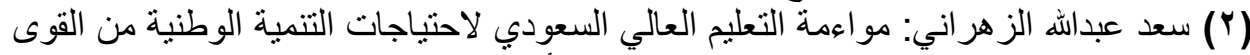

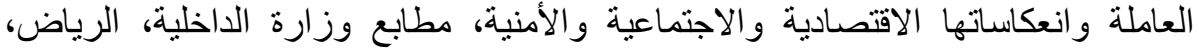




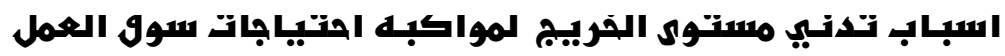

جدول رقم (V) يوضح أسباب تلني مستوى الخريج الحالي ليتناسب واحتياجات سوق العمل

\begin{tabular}{|c|c|c|c|c|c|c|c|c|c|c|c|c|}
\hline \multicolumn{6}{|c|}{ أصحاب الأعمال } & \multicolumn{6}{|c|}{ الأفراد الإداريين و العاملين بالجامعة } & \multirow{3}{*}{ المتغيرات } \\
\hline \multicolumn{2}{|c|}{ قليلة } & \multicolumn{2}{|c|}{ متوسطة } & \multicolumn{2}{|c|}{ كبيرة } & \multicolumn{2}{|c|}{ قليلة } & \multicolumn{2}{|c|}{ متوسطة } & \multicolumn{2}{|c|}{ كبيرة } & \\
\hline$\%$ & s & $\%$ & ك5 & $\%$ & ك & $\%$ & ك & $\%$ & ك & $\%$ & ك & \\
\hline rı & 19 & ir & 1 & ๑. & ro & $\wedge$ & $\varepsilon$ & 11 & 9 & $v \leqslant$ & $\mathrm{rv}$ & ما يقلم من مناهج قديم وغير ملائم للواقع \\
\hline 1. & 0 & r. & 10 & \%. & $r$. & $1 \leq$ & $\mathrm{v}$ & m & 11 & 0. & ro & الاهتمام بالجانب العلمي التطبيقي. \\
\hline ir & 1 & $r \varepsilon$ & ir & צ & ry & 1 & r & $r \varepsilon$ & ir & v. & ro & 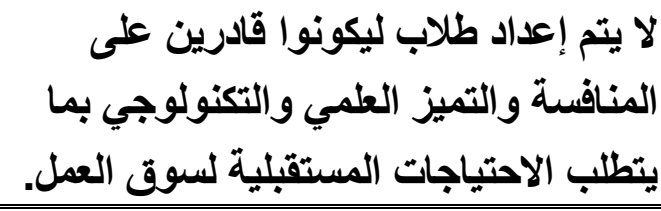 \\
\hline r & 19 & ir & 7 & ๑. & ro & $\varepsilon \varepsilon$ & rY & 7 & $r$ & ๑. & ro & 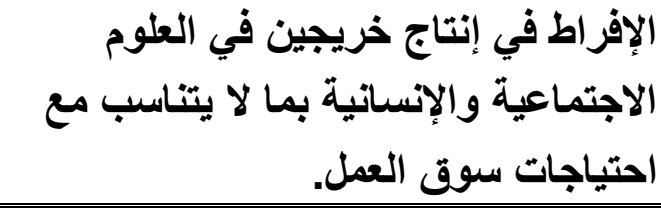 \\
\hline
\end{tabular}


- بالنسبة لروية الإداريين والعاملين بالجامعة : تثير بيانات الجدول رقم

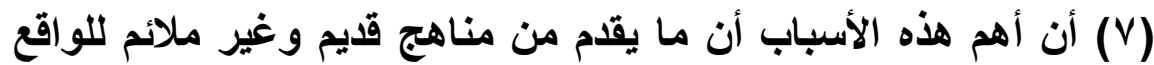

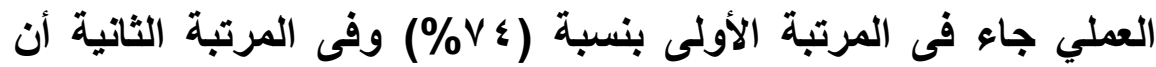

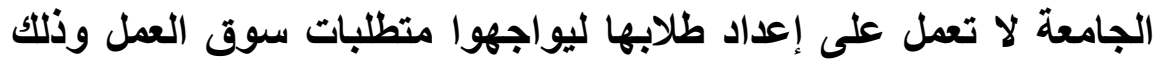

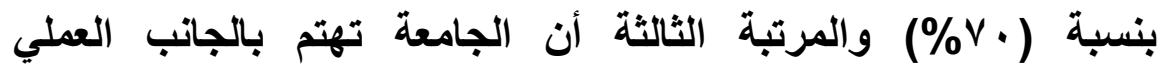
التطبيقي، ويليها أن هناك افراطًا في إنتاج خريجي التهانه العلوم الاجتماعية والإنسانية بنسبة ( • \% \%).

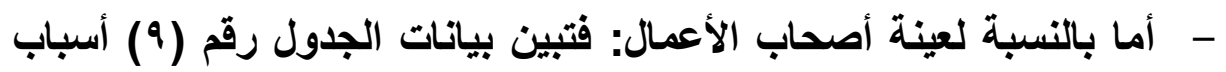
تدني مستوى الخريج الحالي مع احتياجات سوق العمل، أن الجامعة لا لاعبه

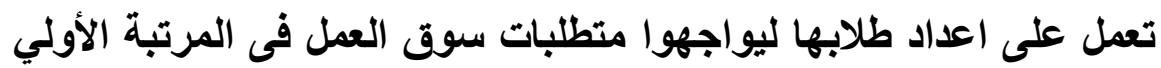
وذلك بنسبة(ع٪\%) والمرتبة الثانية أن الجامعة تهتم بالجانب العملي التطبيقي وذلك بنسبة(·٪\%) والمرتبة الثالثة أن هنائ إفراطًا في إنتاج

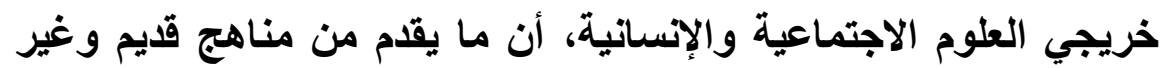

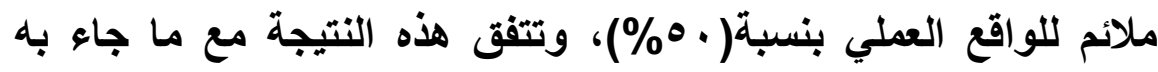
(بورديو ياسرون) الذي أكد على أهمية العلاقة بين مخرجات التهات التعليم العالي

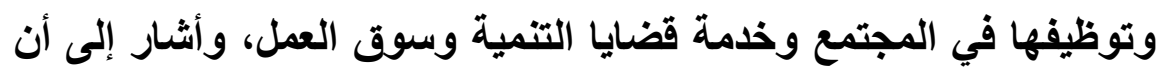

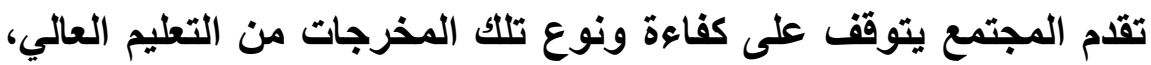

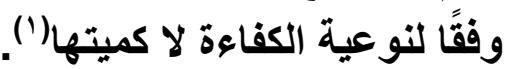


ابباب ضعد المخرجاتت الجامعبه الهالبه

جدول رقم (^) يوضح أسباب ضعف المخرجات الجامعية الحالية

\begin{tabular}{|c|c|c|c|c|c|c|c|c|c|c|c|c|}
\hline \multicolumn{6}{|c|}{ أصحاب الأعمال } & \multicolumn{6}{|c|}{$\begin{array}{c}\text { الأفراد الإداريين والعاملين } \\
\text { بالجامعةة }\end{array}$} & \multirow[t]{3}{*}{ المتغيرات } \\
\hline \multicolumn{2}{|c|}{ قليلة } & \multicolumn{2}{|c|}{ متوسطة } & \multicolumn{2}{|c|}{ كبيرة } & \multicolumn{2}{|c|}{ قليلة } & \multicolumn{2}{|c|}{ متوسطة } & \multicolumn{2}{|c|}{ كبيرة } & \\
\hline$\%$ & كs & $\%$ & ك & $\%$ & ك5 & $\%$ & ك5 & $\%$ & ك & $\%$ & ك5 & \\
\hline r & 1 & $r$. & 10 & 71 & $\mu \varepsilon$ & $\varepsilon$ & r & Y & 14 & V. & ro & عدم فاعلية البرامج الدراسية الحالية. \\
\hline rq & ir & ๑. & ro & r $\varepsilon$ & ir & $1 \varepsilon$ & V & \& & iv & or & r & صغيرة التكيف مع ضرورة العمل في مجموعات \\
\hline$r \wedge$ & $1 \varepsilon$ & Or & rq & r. & 1 . & 11 & 9 & $\mu \varepsilon$ & iv & $\varepsilon \wedge$ & $r \varepsilon$ & الاجتماعية وراية الخريجين بمفهوم المسئولية \\
\hline 1. & $\bullet$ & $\Delta r$ & rq & $r \wedge$ & 19 & 17 & $\wedge$ & $\leq 7$ & $r r$ & $\mu \wedge$ & 19 & نقص القدرة على الإبداع. \\
\hline
\end{tabular}

- بالنسبة لعينة الإداريين والعاملين بالجامعة: يتضح من بيانات الجدول رقم(^) أسباب ضعف المخرجات الجامعية

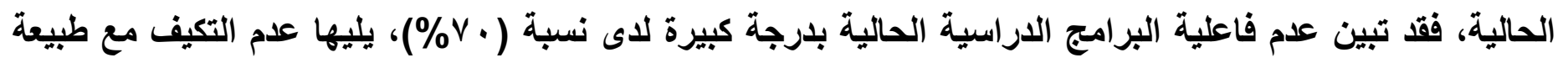

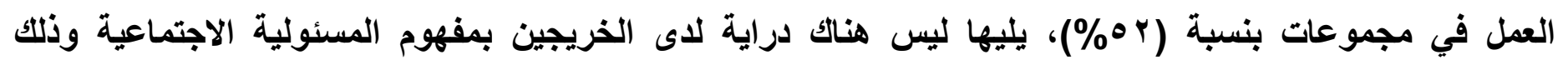

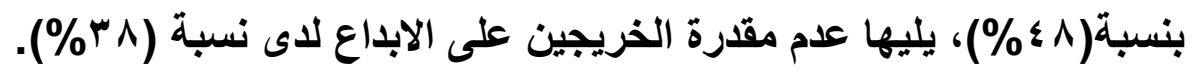


تطبيق نظام الجودة في التعليم الجامعي وتأثيره على مخرجات سوق العمل

- يري أصحاب الاعمال: تثير بيانات الجدول السابق أن السبب الرئيسي

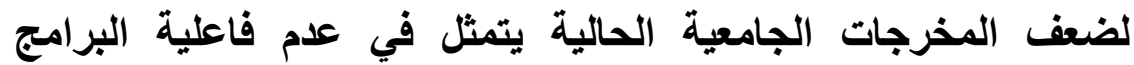
الاراسية الحالية بلرجة متفاوتة بين كبيرة ومتوسطة لاى نسبة

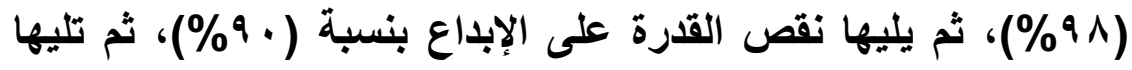

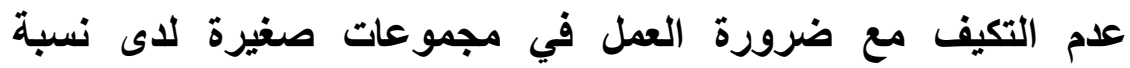

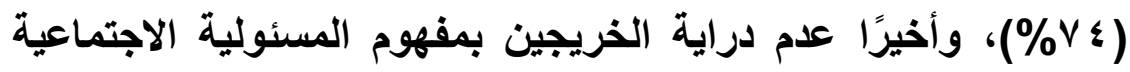

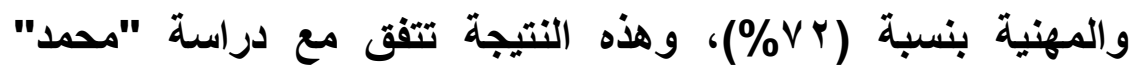

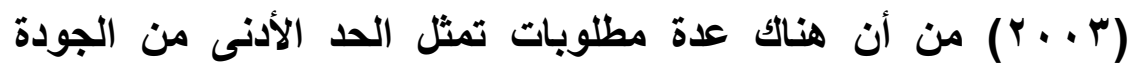

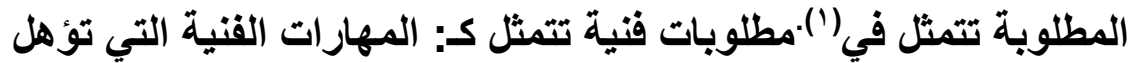
الخريج للالتحاق بسوق العمل، وأيضًا هنالك مطلوبات سلوكية ولتئل والتي

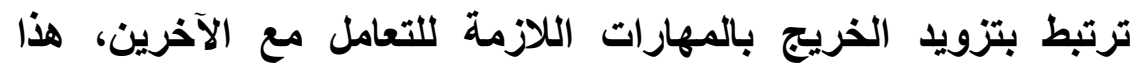
بالإضافة إلى المطلوبات الإبلاعية والتي تختص بتنمية مهارات الإبداع والقدرة على الابتكار وعلى التجديد.

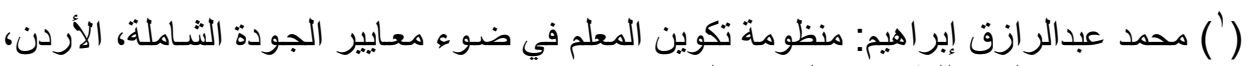

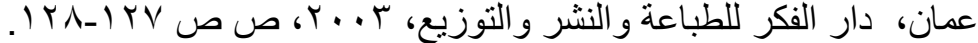


كيفية ربطالتنصصات المالية بـمتطلبات سلوق العمل الفعلية.

جدول رقم (9) يوضح ربط التخصصات الحالية بمتطلبات سوق العمل الفعلية

\begin{tabular}{|c|c|c|c|c|c|c|c|c|c|c|c|c|}
\hline \multicolumn{6}{|c|}{ أصحاب الأعمال } & \multicolumn{6}{|c|}{ الأفراد الإداريين والعاملين بالجامعة } & \multirow{3}{*}{ المتغيرات } \\
\hline \multicolumn{2}{|c|}{ قليلة } & \multicolumn{2}{|c|}{ متوسطة } & \multicolumn{2}{|c|}{ كبيرة } & \multicolumn{2}{|c|}{ قليلة } & \multicolumn{2}{|c|}{ متوسطة } & \multicolumn{2}{|c|}{ كبيرة } & \\
\hline$\%$ & ك5 & $\%$ & ك5 & $\%$ & ك5 & $\%$ & ك & $\%$ & ك & $\%$ & ك & \\
\hline$\varepsilon$ & $r$ & r $\varepsilon$ & ir & Vr & rq & $\varepsilon$ & r & r & 11 & 7. & $r$. & يتم تخريج الطلاب الجامعيين بالتخصصات المطلوبة لسدات الاحتياجة الفعلية. \\
\hline 7 & $r$ & $1 \varepsilon$ & $v$ & $\Lambda$. & $\varepsilon$. & 11 & 9 & rq & $1 \%$ & 07 & r^ & تهالم الجامعة بدراسة التخصصات المطلوبة في الوقت \\
\hline$\varepsilon$ & $r$ & $r$. & 1 . & $v^{7}$ & $\mathrm{r} \Lambda$ & $\varepsilon$ & r & $r \wedge$ & $1 \varepsilon$ & $7 \wedge$ & \& & تسوق الجامعة بمتابعة الخريجين وتبحث عن مدى ملاعمتهم \\
\hline
\end{tabular}

- بالنسبة لعينة الإداريين والعاملين بالجامعة : يوضح الجدول رقم (9) أن الجامعة تقوم بربط التخصصات الحالية بحاجات

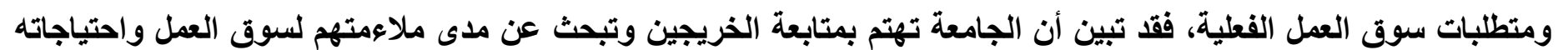

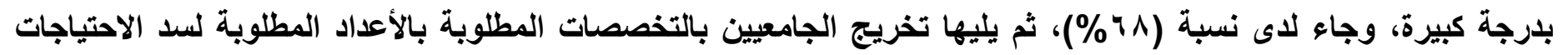

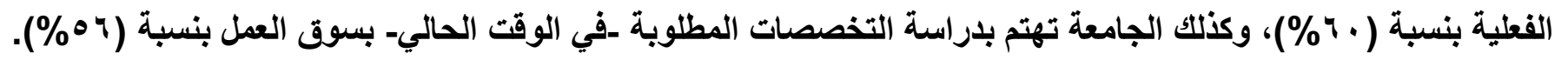
- - أما بالنسبة لعينة أصحاب الأعمال: فتوضح بيانات الجدول أن الجامعة تهتم بلرجة كبيرة بدراسة التخصصات المطلوبة -في

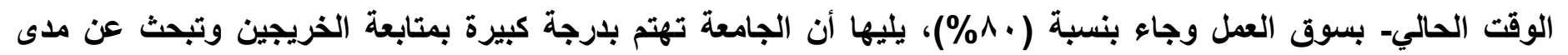




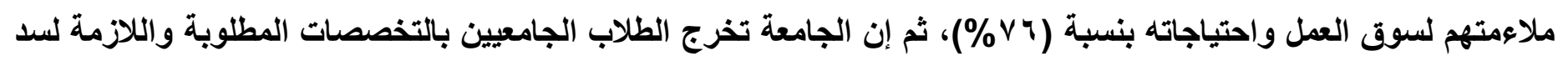

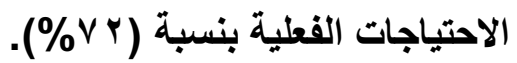

\section{- ما تراعيه الجامعة لمواكبة متطلبات سورة العمل.}

- - جدول رقم (• (1) يوضح ما تراعيه الجامعة لمواكبة متطلبات سوق العمل

\begin{tabular}{|c|c|c|c|c|c|c|c|c|c|c|c|c|}
\hline \multicolumn{6}{|c|}{ أصحاب الأعمال } & \multicolumn{6}{|c|}{ الأفراد الإداريين والعاملين بالجامعة } & \multirow{3}{*}{ المتغيرات } \\
\hline \multicolumn{2}{|c|}{ قليلة } & \multicolumn{2}{|c|}{ متوسطة } & \multicolumn{2}{|c|}{ كبيرة } & \multicolumn{2}{|c|}{ قليلة } & \multicolumn{2}{|c|}{ متوسطة } & \multicolumn{2}{|c|}{ كبيرة } & \\
\hline$\%$ & ك & $\%$ & ك & $\%$ & ك & $\%$ & ك & $\%$ & ك & $\%$ & ك & \\
\hline$r \leq$ & Ir & 11 & 9 & $\Delta \wedge$ & rq & $r \cdot$ & 1 . & rr & 11 & $\bullet \wedge$ & rq & السوتم بكيفية توزيع الطلاب بين التخصصات حسب متطلبات \\
\hline 11 & 9 & r $\varepsilon$ & ir & $\bullet \wedge$ & rq & ir & 7 & $r \cdot$ & 1 . & 71 & $r \varepsilon$ & بشضرك قطاع العمل معه في تحديد سياسة القبول الجامعي في \\
\hline $1 \leq$ & v & $\Delta \wedge$ & rq & rᄉ & $1 \varepsilon$ & 11 & 9 & or & rq & $r \cdot$ & 10 & 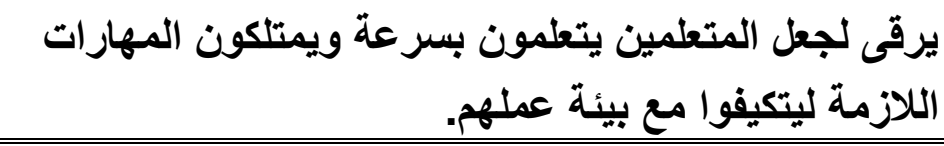 \\
\hline $1 \varepsilon$ & V & $\mu \wedge$ & 19 & $\varepsilon \wedge$ & $r \leq$ & 17 & $\Lambda$ & $\mu \wedge$ & 19 & $\leqslant 7$ & rr & يهيئ المناهج الدراسية تبعًا لحاجات سوق العمل. \\
\hline$r \cdot$ & 10 & $\leqslant r$ & Y & rA & $1 \leq$ & 11 & 9 & $\leq \varepsilon$ & rr & rᄉ & 19 & 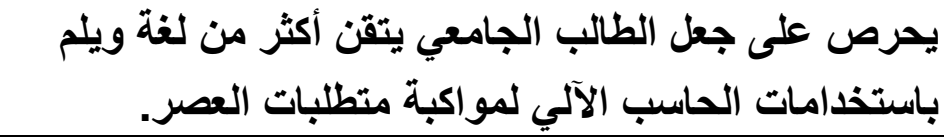 \\
\hline
\end{tabular}




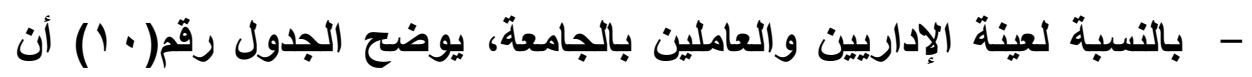

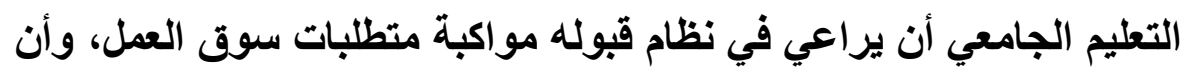

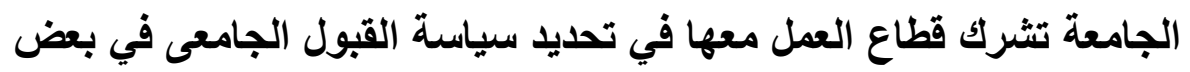

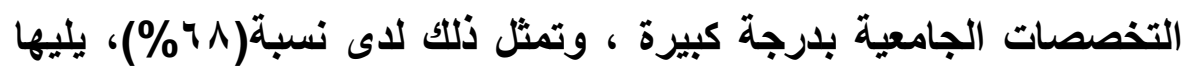

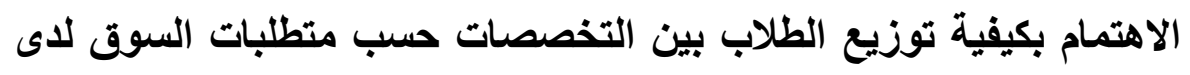

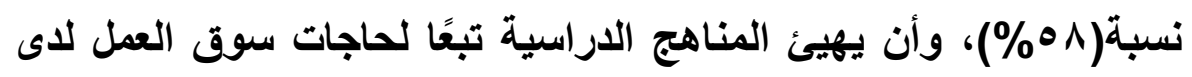

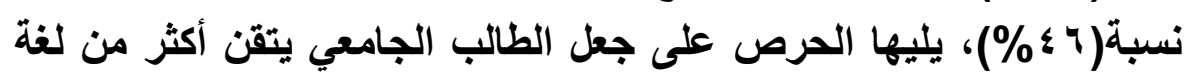

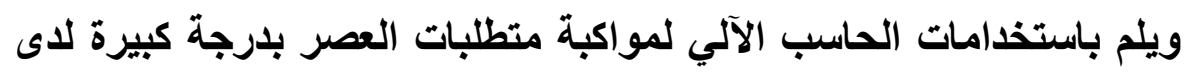

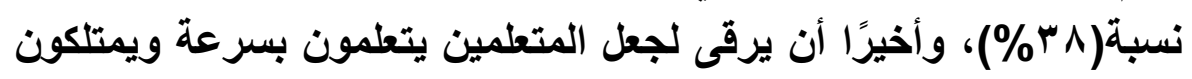

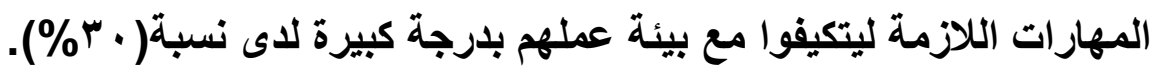

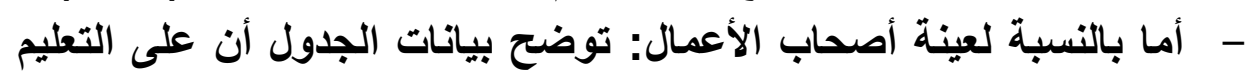

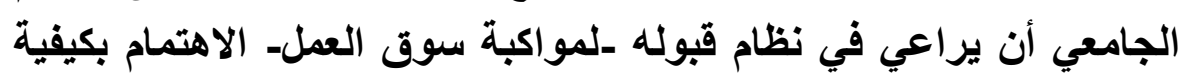

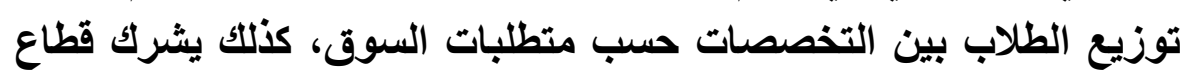

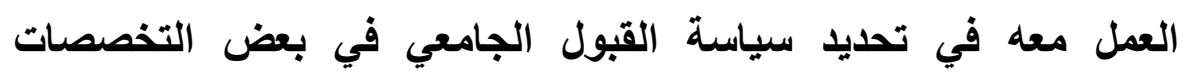

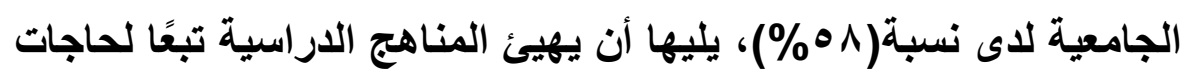

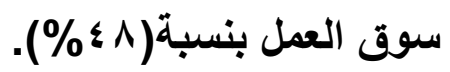
ما أهم المعوقات التي تحول دون تطبيق الجيق نظام الجودة من وجهة نظر الإداريين و العاملين بالجامعة وأصحاب الأعمال؟ 
جدول رقم (1') يوضح أهم المعوقات التي تحول دون تطبيق نظام الجودة

\begin{tabular}{|c|c|c|c|c|c|c|c|c|c|c|c|c|}
\hline \multicolumn{6}{|c|}{ أصحاب الأعمال } & \multicolumn{6}{|c|}{ الأفراد الإداريين والعاملين بالجامعة } & \multirow{3}{*}{ المعوقات التي تحول دون تطبيق الجودة } \\
\hline \multicolumn{2}{|c|}{ ضعيفة } & \multicolumn{2}{|c|}{ متوسطة } & \multicolumn{2}{|c|}{ كبيرة } & \multicolumn{2}{|c|}{ 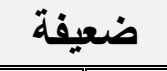 } & \multicolumn{2}{|c|}{ متوسطة } & \multicolumn{2}{|c|}{ كبيرة } & \\
\hline$\%$ & ك & $\%$ & ك & $\%$ & ك & $\%$ & ك & $\%$ & s & $\%$ & ك & \\
\hline - & - & rq & IT & $v \varepsilon$ & rV & - & - & rq & 14 & $v \varepsilon$ & rv & الكثافة الطلابية داخل الكليات \\
\hline$\wedge$ & $\varepsilon$ & $\leq 4$ & r & $\leq 4$ & r & $\wedge$ & $\varepsilon$ & $\leq 4$ & r & 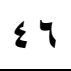 & r & عدم تفهم ماهية الجودة \\
\hline ir & 1 & $\leq 4$ & r & $\leq r$ & r) & ir & 7 & $\leq 4$ & r & $\leqslant r$ & ri & عدم الاقتتاع بالجودة ومدى أهميتها \\
\hline$r$. & 1 . & $r \varepsilon$ & ir & 04 & rı & $\{$. & r. & r & 1 & $0 \wedge$ & rq & علتعلم مما أثر الإمكانات المناسبة مودة العملية التعليميةل وأدوات \\
\hline$\wedge$ & $\varepsilon$ & r. & 1. & vr & ry & r & 1 & ฯ & rr & or & Y & عظام الجودة بالثشكل الأمثل المادية التي تتيح تطبيق \\
\hline$\varepsilon$ & r & r. & 1. & $v_{4}$ & re & $\varepsilon$ & r & r. & 1. & $v^{4}$ & rı & الإجراءات الروتينية و البيروقراطية. \\
\hline 1 & $r$ & rs & 19 & 04 & rı & 1 & $r$ & re & 19 & 04 & rı & ضعف الوعي بأهمية تطبيق نظام الجودة. \\
\hline 1. & 0 & rr & 19 & $0 \wedge$ & rq & 1. & 0 & rr & 19 & 01 & rq & غموض الروئة المستقبلية لنظام الجودة. \\
\hline ir & 7 & $\leqslant r$ & ri & $\leq 4$ & r & ir & 7 & $\varepsilon r$ & ri & ฯ & rr & مقاومة التغيير. \\
\hline 9 & $\mu$ & re & 19 & 04 & rA & 7 & $r$ & re & 19 & 09 & rA & الخوف من كل ما هو جديد. \\
\hline
\end{tabular}




\begin{tabular}{|c|c|c|c|c|c|c|c|c|c|c|c|c|}
\hline \multicolumn{6}{|c|}{ أصحاب الأعمال } & \multicolumn{6}{|c|}{ الأفراد الإداريين والعاملين بالجامعة } & \multirow{3}{*}{ المعوقات التي تحول دون تطبيق الجودة } \\
\hline \multicolumn{2}{|c|}{ ضعيفة } & \multicolumn{2}{|c|}{ متوسطة } & \multicolumn{2}{|c|}{ كبيرة } & \multicolumn{2}{|c|}{ ضعيفة } & \multicolumn{2}{|c|}{ متوسطة } & \multicolumn{2}{|c|}{ كبيرة } & \\
\hline$\%$ & 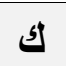 & $\%$ & ك5 & $\%$ & ك & $\%$ & ك & $\%$ & ك5 & $\%$ & ك5 & \\
\hline ir & 7 & $r \varepsilon$ & iv & $0 \leqslant$ & $r v$ & ir & 7 & \& & iv & 0 \& & rv & الخوف من فقد السلطة أو المكانة نتيجة التغيير \\
\hline$\varepsilon$ & r & $\varepsilon r$ & Y & $0 \leqslant$ & rv & $\varepsilon$ & r & $\varepsilon r$ & Y & $0 \leqslant$ & rv & تعسين الجودة. \\
\hline r & 1 & $\leq 7$ & $r r$ & or & Y & $r$ & 1 & \& & rr & Or & rq & القرارات. \\
\hline$\varepsilon$ & $r$ & ع & IV & Tr & r & $\varepsilon$ & $r$ & & IV & $7 r$ & r & العالي (قيم- إحداث التغيير المطلوب في نظام التعليم \\
\hline$r$ & 1 & $\varepsilon$. & $r$. & $\Delta \wedge$ & rq & $r$ & 1 & $\varepsilon$. & r. & $0 \wedge$ & rq & مفاميم وجود صورة واضيب تحسين الجودة لدى الجميع عن \\
\hline - & - & rr & 17 & 71 & $\Gamma \varepsilon$ & - & - & $r r$ & 17 & 71 & $r \varepsilon$ & أولياء أمور) في وضاركة المجتمع الخارجى(أصحاب أعمال- \\
\hline
\end{tabular}


- بالنسبة لعينة الإداريين والعاملين بالجامعة: تثثير بيانات الجدول رقم(1')

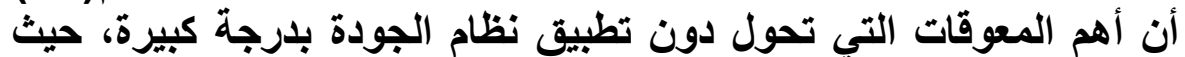

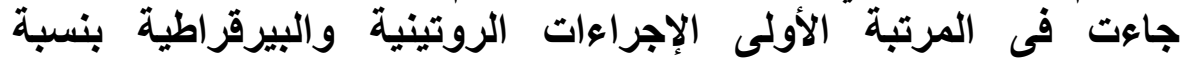

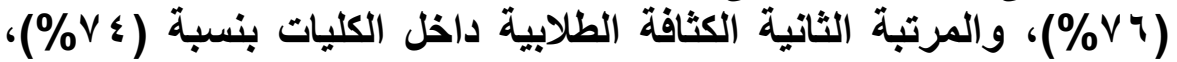

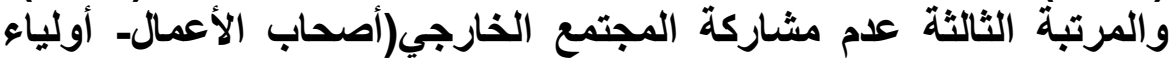

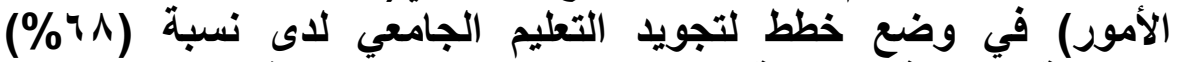

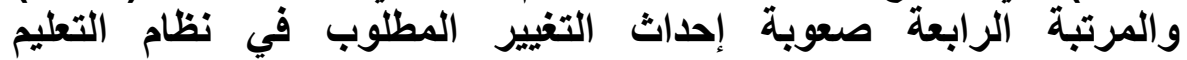

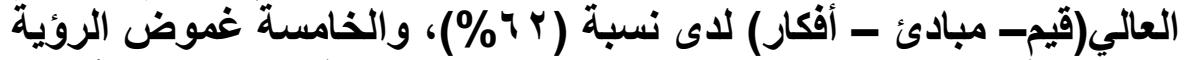

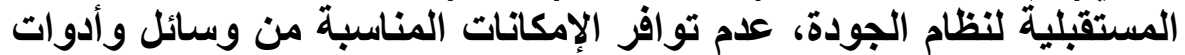

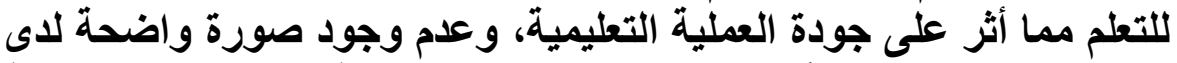

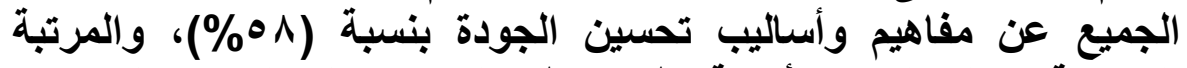

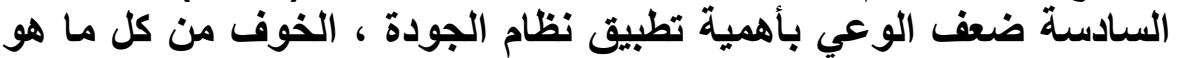

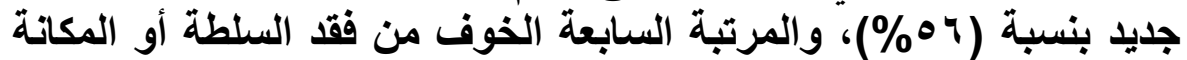

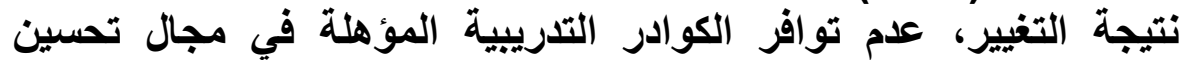

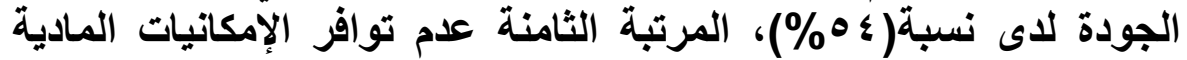

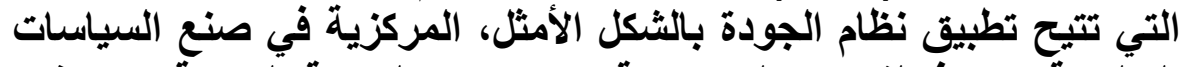

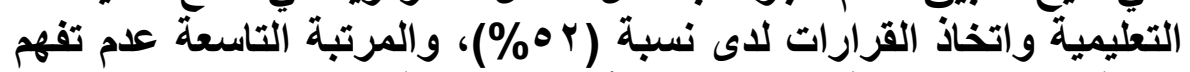

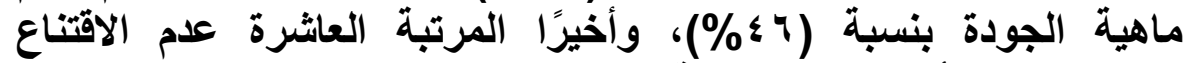

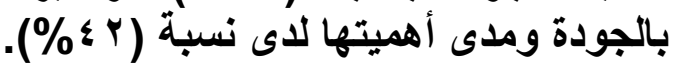

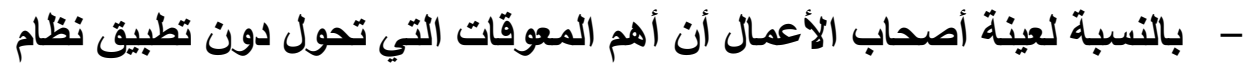

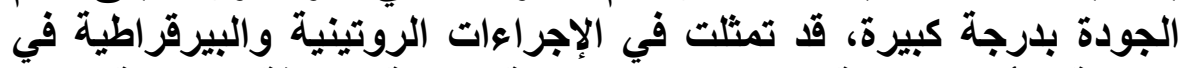

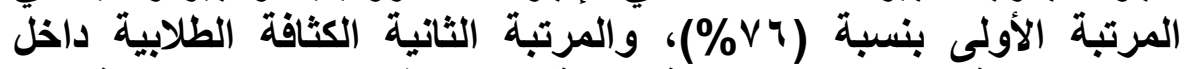

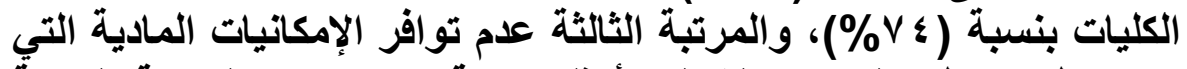

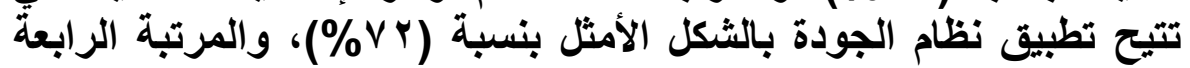

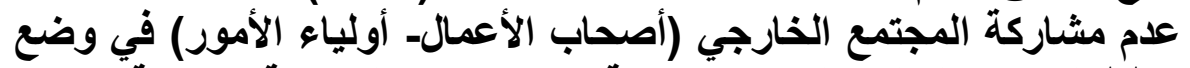

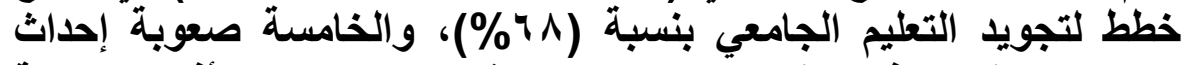

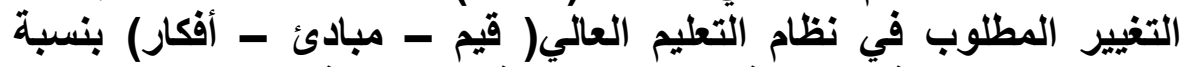

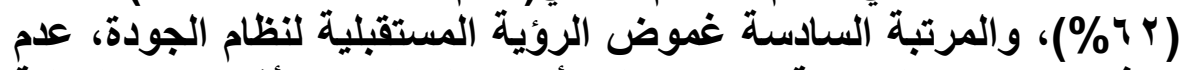

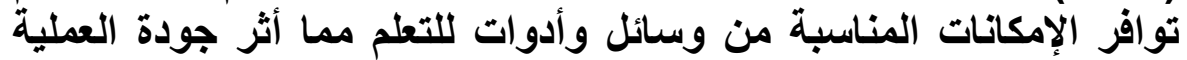

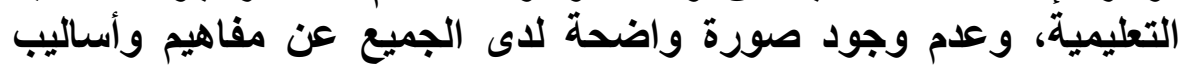

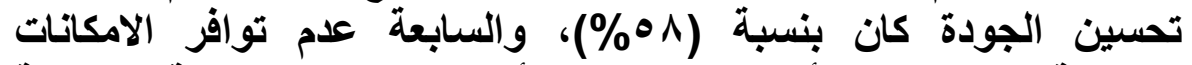

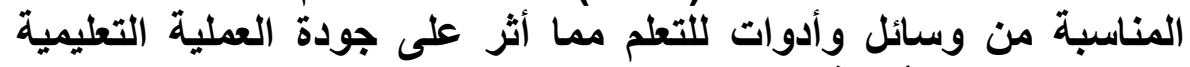

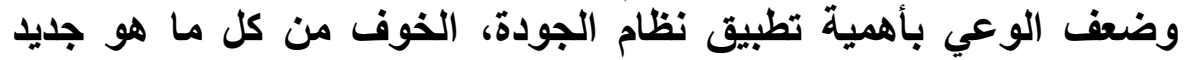

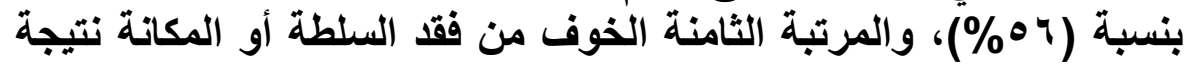


التغيير وعام توافر الكوادر التدريبية المؤهلة في مجال تحسين الجودة

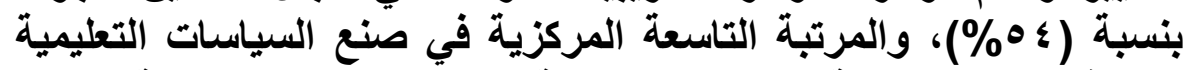

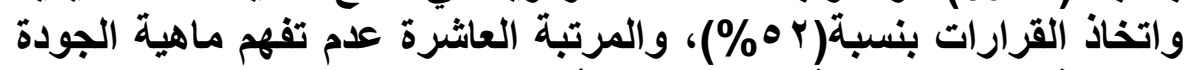

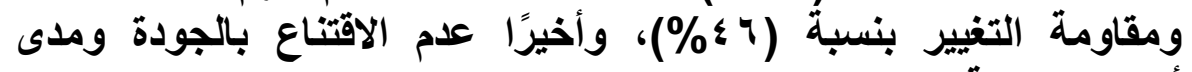
أهميتها بنسبة (r § \%).

\section{نتائج الدراسة:}

- يرى أعضاء هيئة التدريس: أن الجامعة وكلياتها تراعي عند بناء

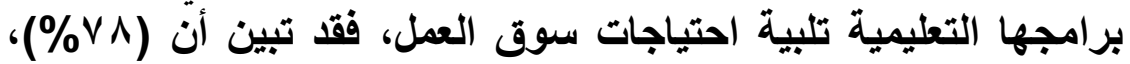

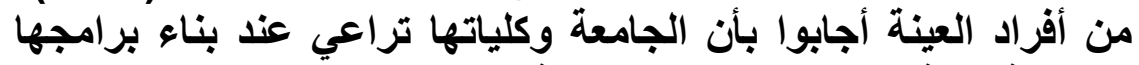
التعليمية تلبية احتياجات السوق الفعلية.

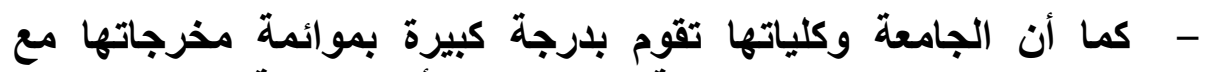

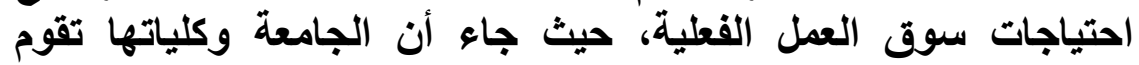

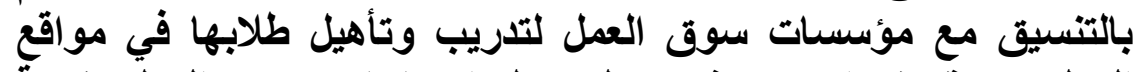

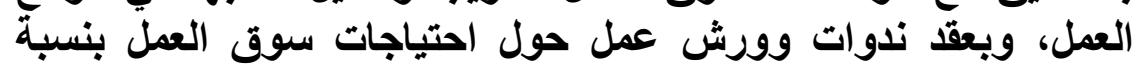

$$
\text { . }(\% \vee \wedge)
$$

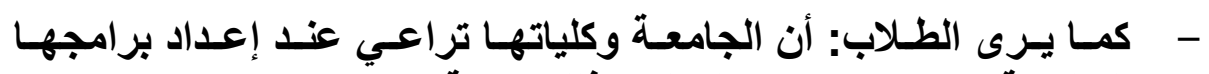

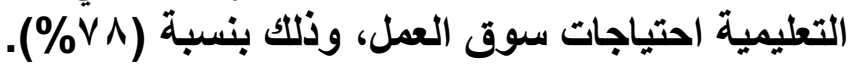

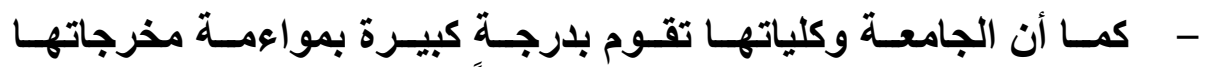

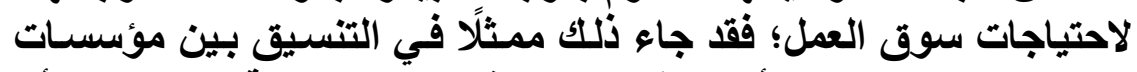

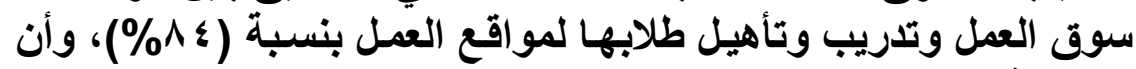

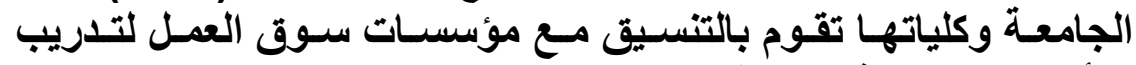

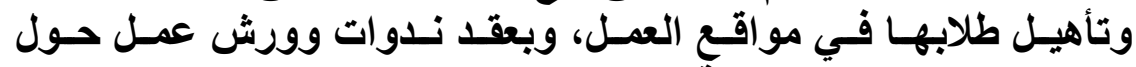

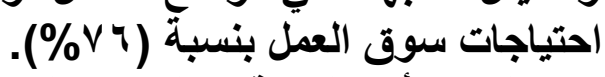

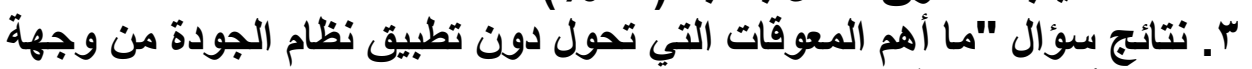

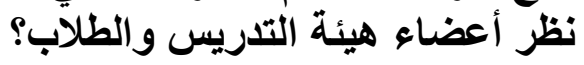

- يرى أعضاء هيئة التدريس: أن أهم المعوقات هي المعوقات المئه المركزية

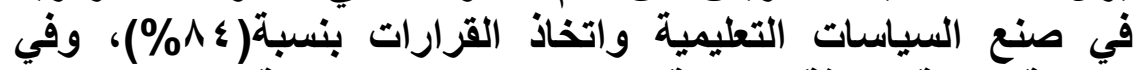

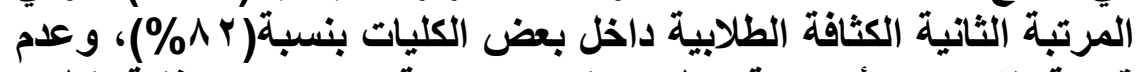

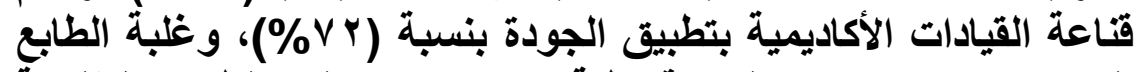

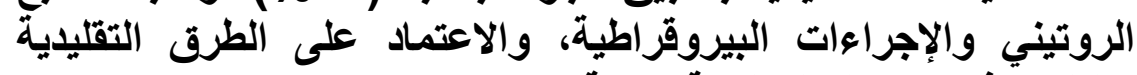

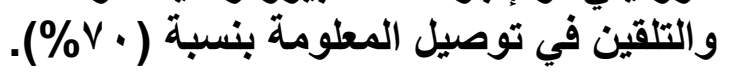

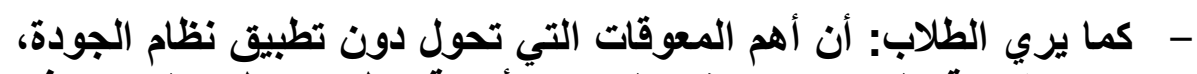

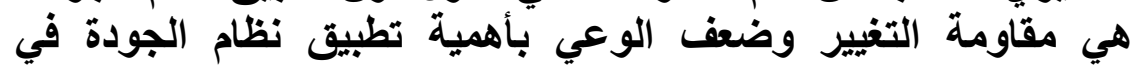

$$
1 \cdot 0
$$


المرتبة الأولى بنسبة (Y^\%)، وعدم وجود روئية واضحة لدى الجميع

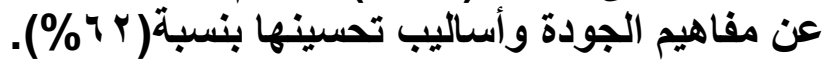

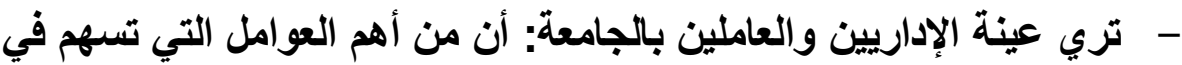

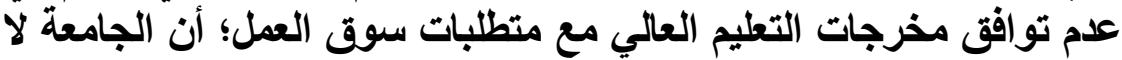

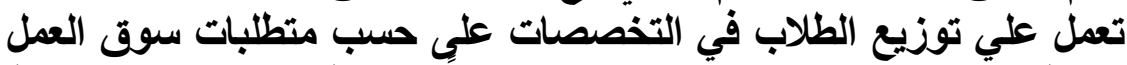

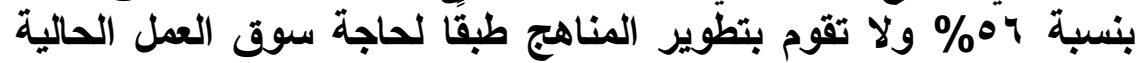

$$
\text { بنسبة) • ب0\%). }
$$

- - بالنسبة لأصحاب الأعمال: يرى أصحاب الأعمال أن العوامل التي تسهم في

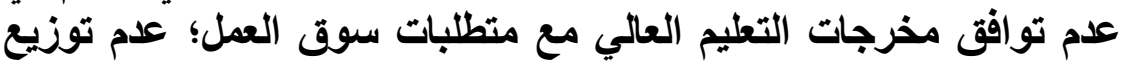

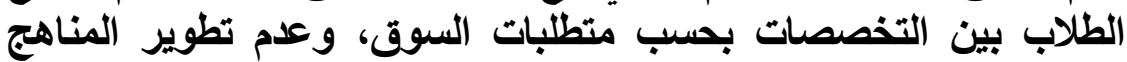

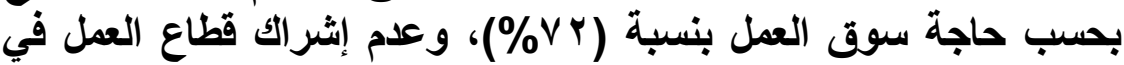

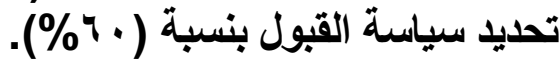

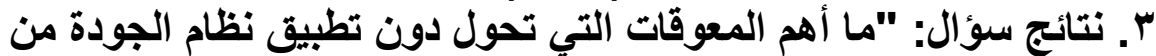

وجهة نظر الأفراد الإداريين والعاملين بالجامعة وأمات وأصحاب الأعمال؟

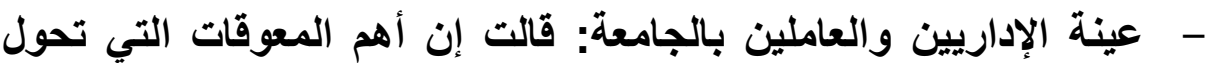

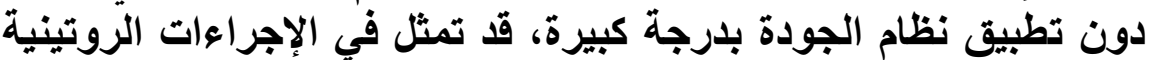

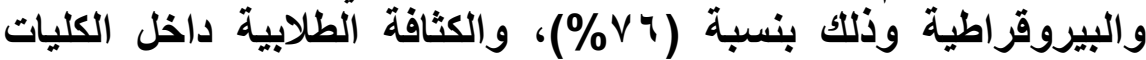

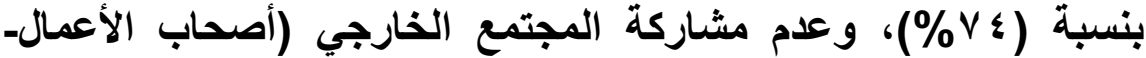

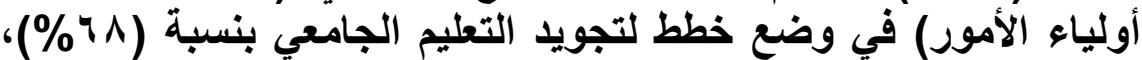

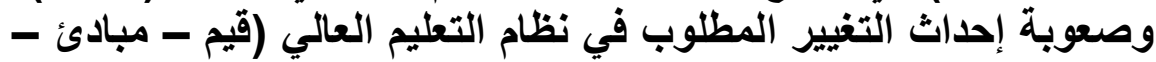

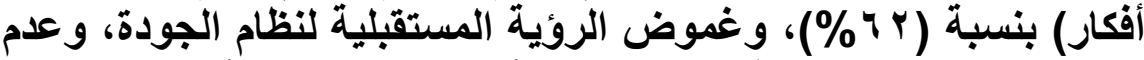

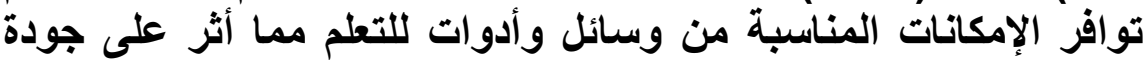

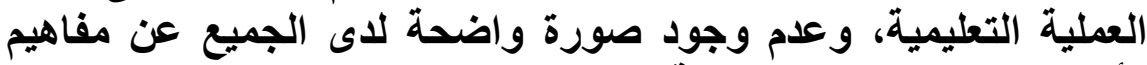

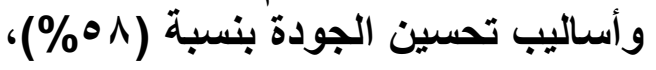

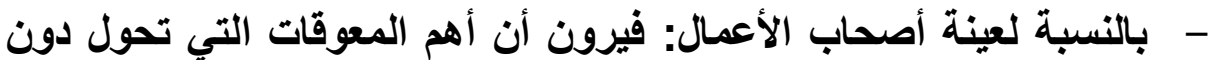

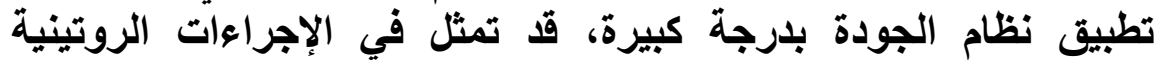

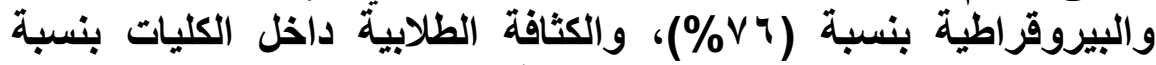

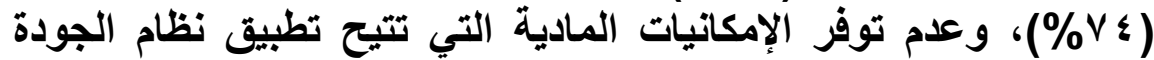

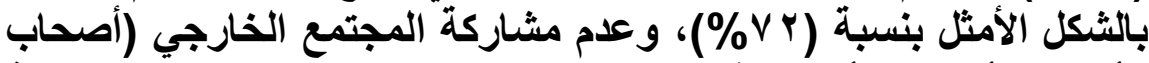

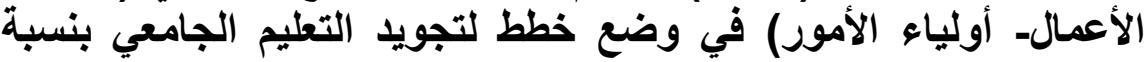

. $(\% 7 \Lambda)$

يتضح وجود جملة من المعوقات التي تحد من تطبيق نظام ضمان الجودة في ودي

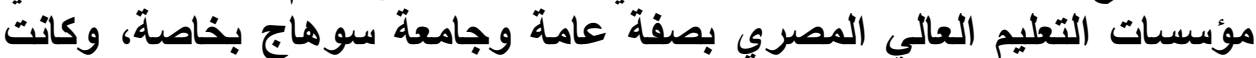
ذات أهمية متفاوتة من وجهة نظر عينة الدراسة، فقد شكلت المعوقات المعات المركزية 


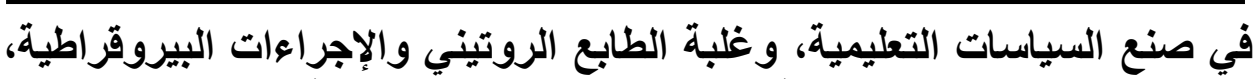

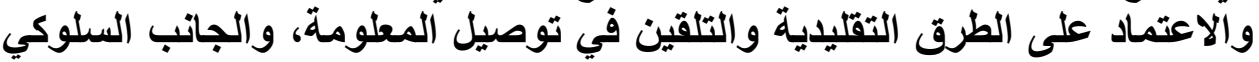
الخاص بمقاومة تطبيق الجودة، والجاتب التنظيمي على مستوى الجامعة.

\section{توصبات الدراسةة:}

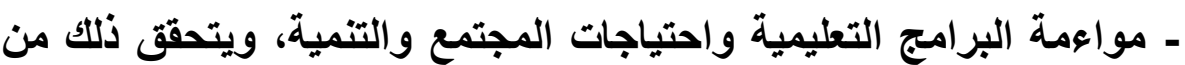

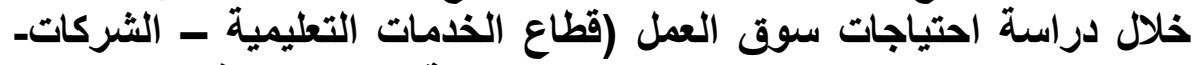

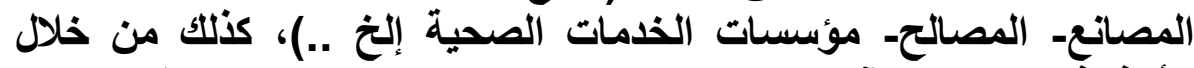

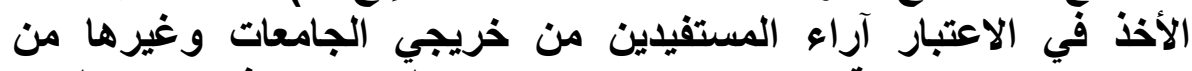

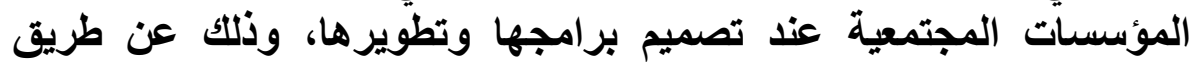
تشكيل فرق عمل مشتركة من أطراف عدة للقيام بذألك.

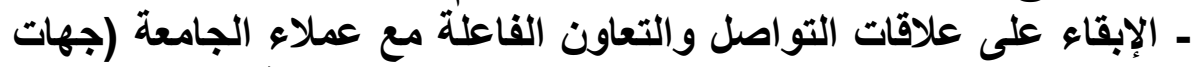

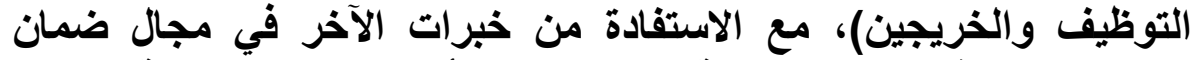

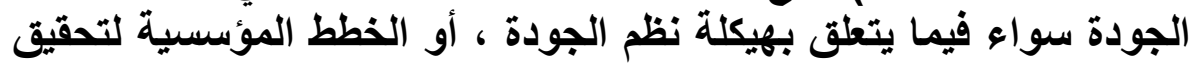

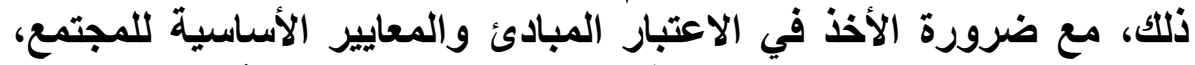

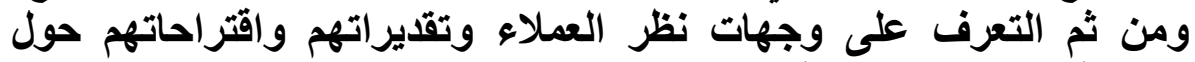

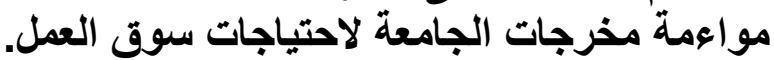

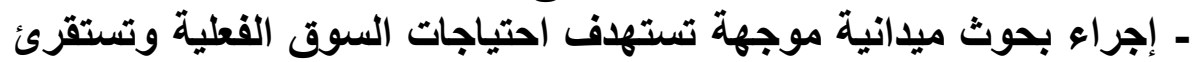

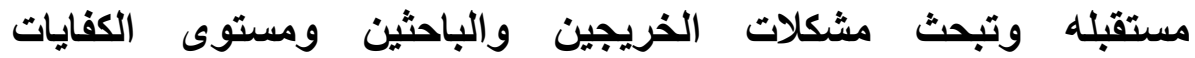
والمهارات، وأوجه القصور في الخدمات التهرئ الاجتماعية.

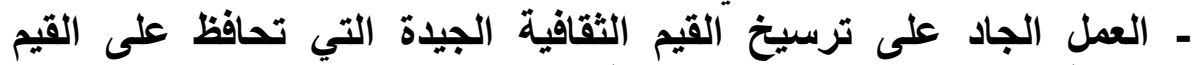

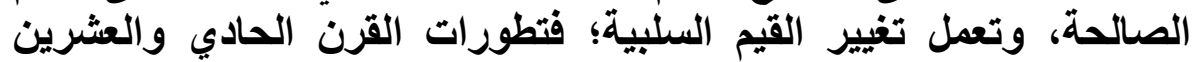

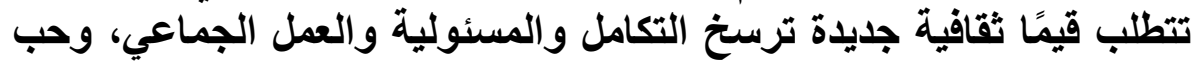

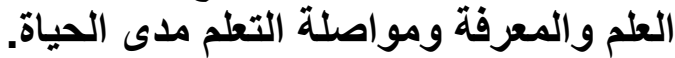

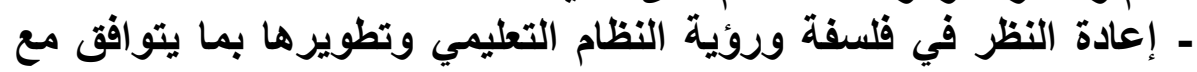

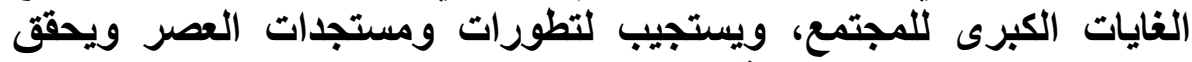
الحصول على مخرجات عالية الجودة.

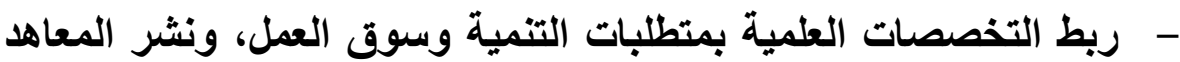
القنية والمهنية التي تتولى تأهيل المتعلمين للمهنية المئين المطلوبة في العصر 
• إبراهيم أنيس وآخرون: المعجم الوسبط، القاهرة، مجمع اللغة

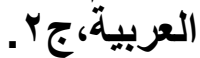

إبراهيم عبده: دور هندسة القيمة في ترشيد تكلفة التعليم الجامعي،

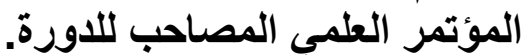

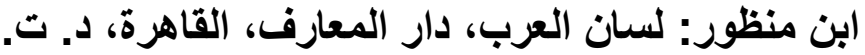

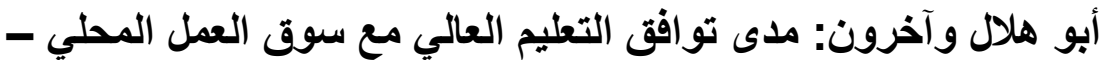

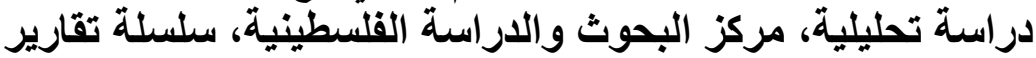

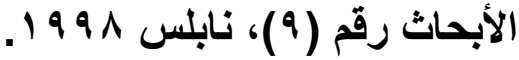

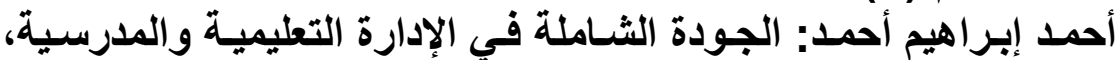

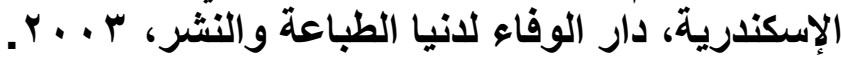

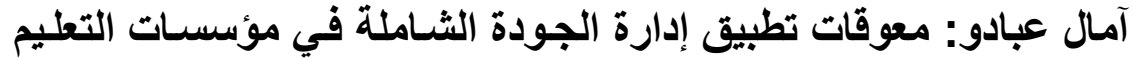

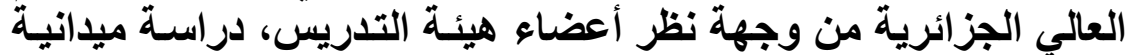

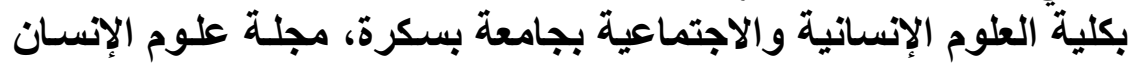

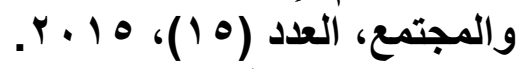

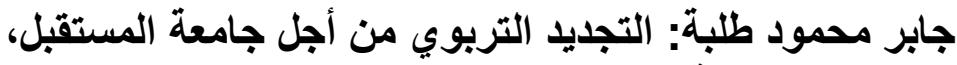
المنصورة، مكتبة الإيمان،

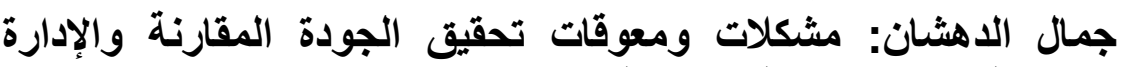

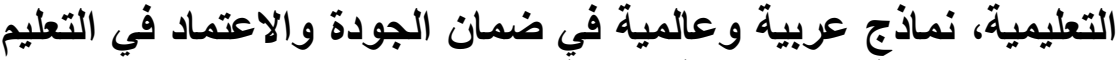

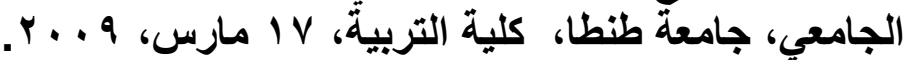

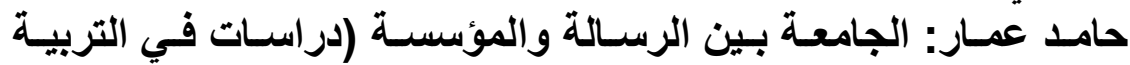

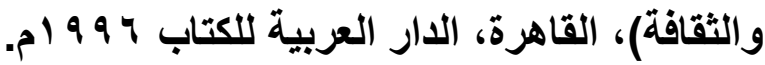

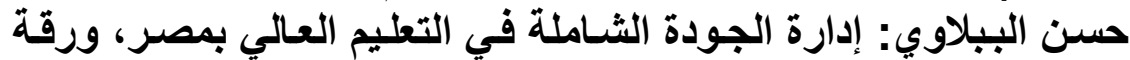

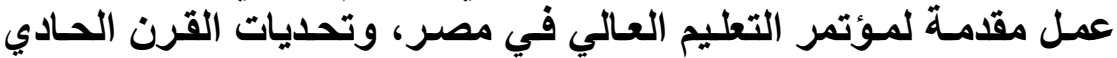

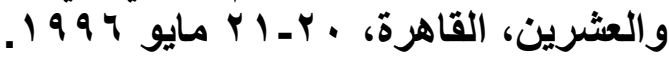

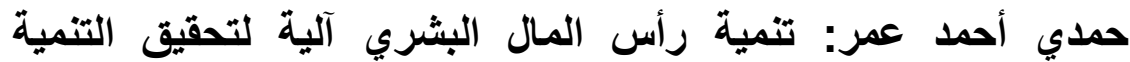

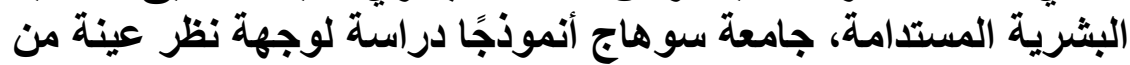

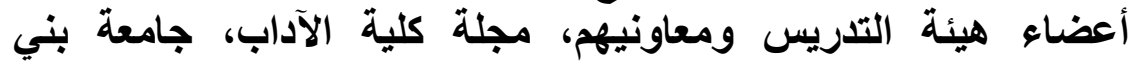

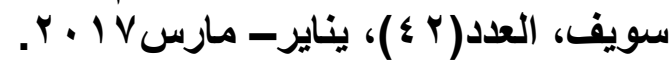

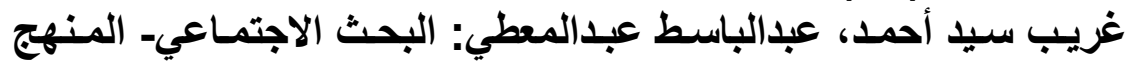

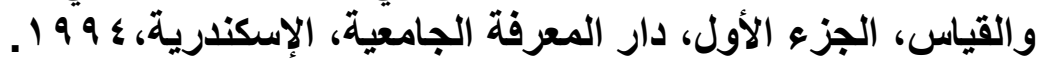


فاروق عبده فليه: اقتصاديات التعليم: مبادئ راسخة واتجاهـات حديثة، وإنة

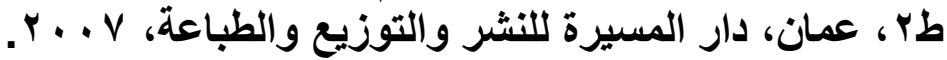

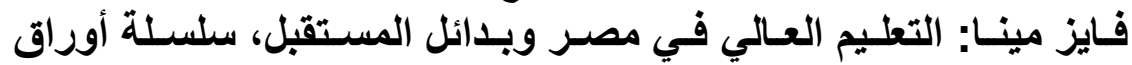

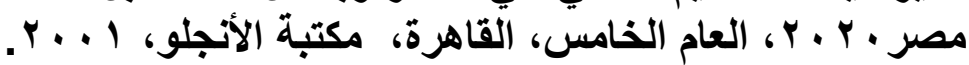

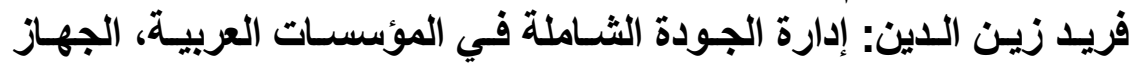
المركزي للتنظيم والإدارة، القاهرة، التهن،

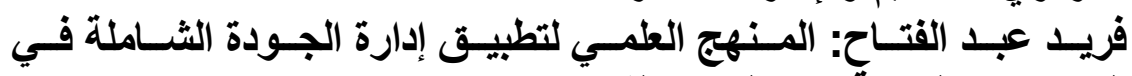

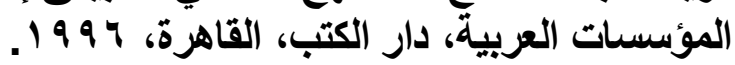

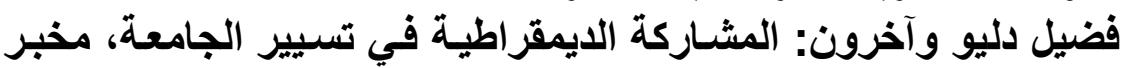

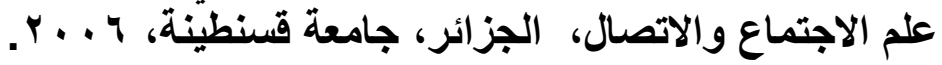

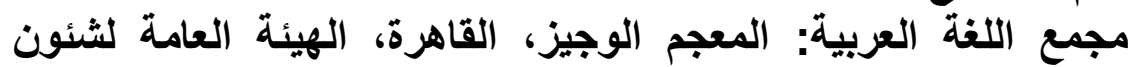

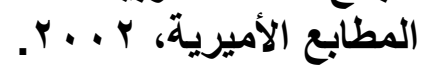
محمد أبو الغار: إهدار واستقلال الجاله الجامعات، القاهرة، دار الكتب

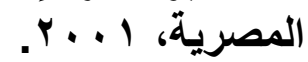

محمد الحوث، عدلي شاذلي: التهلية التعليم والتمية، جمهورية مصر العربية،

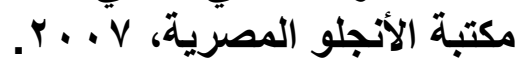

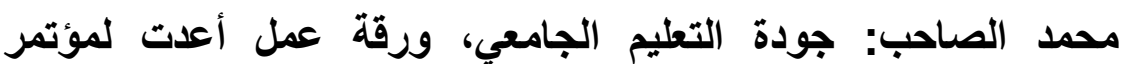

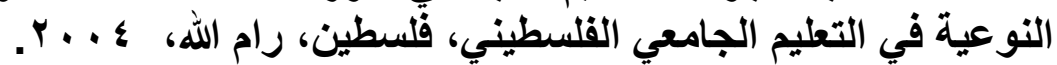

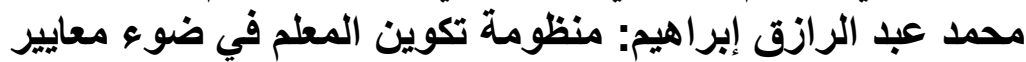

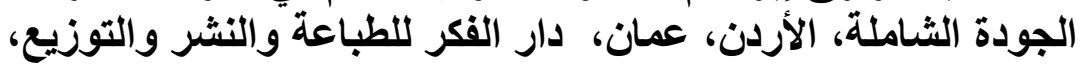
r...r محمد عزت عبد الموجود: من قضسايا التعليم والتنميـة، مستقبل التربيـة

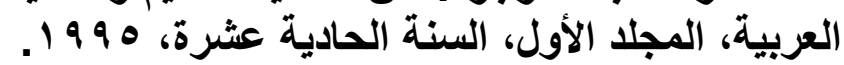

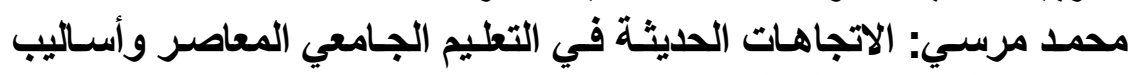

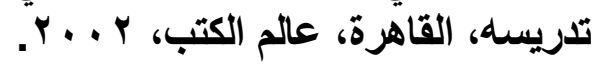
محمود عباس عابدين: قضايا تخطيط التعليم واقتصادياته باله بين العالمية

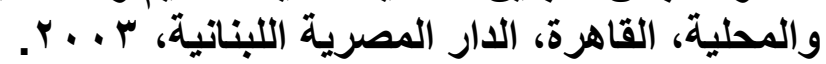

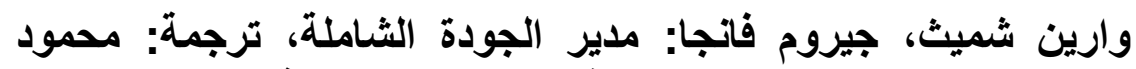

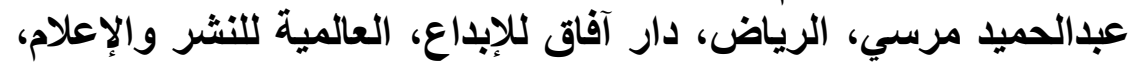

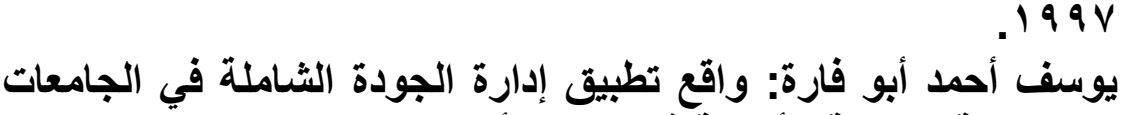

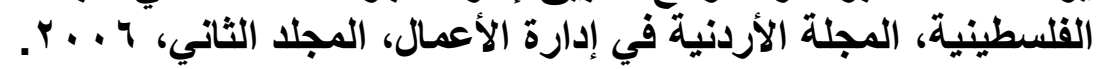


تطبيق نظام الجودة في التعليم الجامعي وتأثيره على مخرجات سوق العمل

المراجِم الأجنـبـةبة:

- Bonser, C "Total Quality Education", Public administration Review, No(52),1999.

- David B,Gralnik,Websters, "New World Dictionary", New York, Mass Merriam Webster Inc, 1981.

- OFinchm, Aikyna, et.al, "changing the culture of colleges and universities to make them more adaptive", Intellect Base International Consortium,vol.3,No (7), 2010.

- Higher Edueation News Itter, Newtechnology Anopporition and challenge for Availabl in:Education awailableat. http://w/crueorg bolet edu, in Gzhtm. 2007.

- Link, D.waster S,. New world Dictionary ", New York: MCGraw Hill .2002.

- Peterson Obara,Magutumop,"Quality Management Pactices Keny an Educational", Institution,The Case Of University Of Nairobi African Journal Of Business\& Management(A), BUMA, Vol(1),2010,P.144

- Rhodes ,Lewis .A ,." On the road to Quality", Education Leader Ship, Vol. 49, No(6), March,1992. 